\begin{tabular}{|c|c|}
\hline 嗬夜 & $\frac{\text { The Athens Journal of }}{\text { Humanities \& Arts }}$ \\
\hline
\end{tabular}

Volume 8, Issue 1, January 2021

Articles

Front Pages

ALBRECHT CLASSEN

Globalism in Medieval Literature? Pre-Modern Perspectives in Poetic Projections: Wolfram von Eschenbach's Parzival, Konrad Fleck's Flore und Blancheflor, and Reinfried von Braunschweig

\title{
WILLIAM O'MEARA
}

John Dewey on Stages of Morality and Self-Realization Confronting Death

BOGNA モAKOMSKA

Images of Animals in Neolithic Chinese Ceramic

VANDA SREBOTNJAK

Giuseppe Ungaretti Reading of the Correspondence with Pea, Prezzolini, Soffici and Papini from a New Perspective 


\section{Mission}

ATINER is an Athens-based World Association of Academics and Researchers based in Athens. ATINER is an independent and non-profit Association with a Mission to become a forum where Academics and Researchers from all over the world can meet in Athens, exchange ideas on their research and discuss future developments in their disciplines, as well as engage with professionals from other fields. Athens was chosen because of its long history of academic gatherings, which go back thousands of years to Plato's Academy and Aristotle's Lyceum. Both these historic places are within walking distance from ATINER's downtown offices. Since antiquity, Athens was an open city. In the words of Pericles, Athens"... is open to the world, we never expel a foreigner from learning or seeing". ("Pericles' Funeral Oration", in Thucydides, The History of the Peloponnesian War). It is ATINER's mission to revive the glory of Ancient Athens by inviting the World Academic Community to the city, to learn from each other in an environment of freedom and respect for other people's opinions and beliefs. After all, the free expression of one's opinion formed the basis for the development of democracy, and Athens was its cradle. As it turned out, the Golden Age of Athens was in fact, the Golden Age of the Western Civilization. Education and (Re)searching for the 'truth' are the pillars of any free (democratic) society. This is the reason why Education and Research are the two core words in ATINER's name. 
The Athens Journal of Humanities \& Arts

ISSN NUMBER: 2241-7702 - DOI: 10.30958/ajha

Volume 8, Issue 1, January 2021

Download the entire issue ( $\underline{\mathrm{PDF}})$

Front Pages

i-xiv

Globalism in Medieval Literature? Pre-Modern

Perspectives in Poetic Projections: Wolfram von

Eschenbach's Parzival, Konrad Fleck's Flore und

Blancheflor, and Reinfried von Braunschweig

Albrecht Classen

John Dewey on Stages of Morality and Self-Realization

45

Confronting Death

William O'Meara

Images of Animals in Neolithic Chinese Ceramic

63

Bogna Eakomska

Giuseppe Ungaretti Reading of the Correspondence

81 with Pea, Prezzolini, Soffici and Papini from a New Perspective

Vanda Srebotnjak 


\title{
Athens Journal of Humanities \& Arts Editorial and Reviewers' Board
}

\author{
$\underline{\text { Editors }}$
}

- Dr. Stephen Andrew Arbury, Head, Arts \& Culture Research Unit, ATINER, Professor of Art History \& Director of the RU Art Museum, Radford University, USA.

\section{Editorial Board}

- Dr. Nicholas Pappas, Vice President of Academic Membership, ATINER \& Professor of History, Sam Houston University, USA.

- Dr. David Philip Wick, Director, Arts and Humanities Research Division, Athens Institute for Education and Research (ATINER) \& Professor of History, Gordon College, USA.

- Dr. Jayoung Che, Head, History Research Unit, ATINER \& Deputy Director of Research, Korean Academy of Greek Studies, South Korea.

- Mr. Benjamin Lewis, Founding Director, The Philology Institute, Wilmore, USA.

- Dr. Corinne Ness, Dean, Division of Arts and Humanities \& Associate Professor of Voice, Director of Music Theatre, Carthage College, USA.

- Dr. Tatiana Tsakiropoulou-Summers, Director, Athens Center for Classical \& Byzantine Studies (ACCBS) \& Director, UA in Greece, Summer Abroad Program, Department of Modern Languages \& Classics, The, University of Alabama, USA.

- Dr. Marié-Heleen Coetzee, Head, Drama Department, \& Chair of the Arts Cluster, University of Pretoria, South Africa.

- Dr. Victoria Tuzlukova, Head of Professional Development and Research Unit, Language Centre, Sultan Qaboos University, Sultanate of Oman.

- Dr. Ariel T. Gutierrez, Academic Member, ATINER \& Chair, Social Sciences Department and Music, Arts, Physical Education \& Health Education Dept., Angeles University Foundation-Integrated School, Philippines.

- Dr. Michael Paraskos, Academic Member, ATINER \& Provost, Cornaro Institute, Cyprus.

- Dr. Nursel Asan Baydemir, Professor, Department of Biology, Faculty of Arts and Science, University of Kirikkale, Turkey.

- Dr. Aieman Ahmad AL-OMARI, Professor - Ph.D. Higher Education Administration, Hashemite University, Faculty of Educational Sciences, Department of Educational Foundations and Administration, Jordan.

- Dr. Poonam Bala, Academic Member, ATINER \& Professor, Amity University, India.

- Dr. Mounis Bekhadra, Academic Member, ATINER \& Professor, University of Tlemcen, Algeria.

- Dr. Jean M. Borgatti, Academic Member, ATINER \& Professor, Department of Fine and Applied Arts, University of Benin, Nigeria.

- Dr. Rachana Chakraborty, Professor, University of Calcutta, India.

- Dr. B. Glenn Chandler, Professor of Music Theory and Fellow to the Effie Marie Cain Regents Chair in Fine Arts Sarah and Ernest Butler School of Music, The University of Texas at Austin, USA.

- Dr. Christine Condaris, Academic Member ATINER and Chairperson \& Professor, Department of Fine \& Performing Arts, Massachusetts College of Liberal Arts, USA.

- Dr. Michael Devine, Founder/Director, Centre for Alternative Theatre Training (CATT) \& Full Professor, Acadia University, Department of English \& Theatre, Canada.

- Dr. Yukihide Endo, Professor Emeritus in English, Department of General Education, School of Medicine, Hamamatsu University, Japan.

- Dr. Edward F. Mooney, Professor Emeritus, Syracuse University, USA.

- Dr. Galina Bakhtiarova, Academic Member, ATINER \& Professor of Spanish, Department 
of World Languages and Literature, Western Connecticut State University, USA.

- Dr. Rodrigo Gouvea, Professor of Philosophy, Federal University of São João del-Rei, Brazil.

- Dr. Hank Hehmsoth, Academic Member, ATINER \& Professor, Texas State UniversitySchool of Music, USA.

- Dr. Christine James, Academic Member, ATINER \& Professor, Valdosta State University, USA.

- Ms. Jill Journeaux, Academic Member, ATINER \& Professor of Fine Arts Education, Coventry University, UK.

- Dr. Bogdan Ataullah Kopanski, Professor, International Islamic University, Malaysia.

- Dr. Irena Kossowska, Academic Member, ATINER \& Professor of Art History, Polish Academy of Sciences, Copernicus University in Torun, Poland.

- Dr. James L. Lawton, Academic Member, ATINER \& Professor, Michigan State University, USA.

- Dr. Jennifer Logan, Professor, Occidental College, Music Department, USA.

- Dr. Margarita Lianou, Academic Member, ATINER \& Professor, University of York, UK.

- Dr. Henrique Marins de Carvalho, Academic Member, ATINER \& Professor, Federal Institute of Science, Education and Technology of Sao Paulo, Brazil.

- Dr. Nicholas Meihuizen, Professor, School of Languages, English Department, North-West University, South Africa.

- Dr. Angela M. Michelis, Philosophy and History Teacher in High School in Italy, PhD (University of Turin), National Italian Title of Professor in Moral Philosophy of II level (associated), Italy.

- Dr. Christopher Mitchell, Professor of Theatre Arts, Eastern Illinois University, USA.

- Dr. Anabela Moura, Academic Member, ATINER \& Professor, Instituto Politécnico de Viana do Castelo, Portugal.

- $\quad$ Dr. Mechthild Nagel, Professor, SUNY Cortland, USA.

- Dr. William O'Meara, Academic Member, ATINER \& Professor, Department of Philosophy and Religion, James Madison University, USA.

- Dr. Eloise Philpot, Academic Member, ATINER \& Professor of Art, Radford University, USA.

- Dr. Alexandria Pierce, Professor, Art History, Savannah College of Art and Design, USA.

- Dr. Laura Virginia Radetich, Professor of History, Faculty of Philosophy and Literature, University of Buenos Aires, Argentina.

- Dr. Giovanna Daverio Rocchi, Full Professor of Greek History, Department of Historical Studies, Faculty of Humanities, University of Milan, Italy.

- Dr. Luiz Paulo Rouanet, Academic Member, ATINER \& Professor, Department of Philosophy and Methods, Federal University of Sao Joao del-Rei, Brazil.

- Dr. Nancy Lee Ryuter, Dance Historian, Teacher, and Choreographer, \& Retired Professor of Dance, Claire Trevor School of the Arts, University of California, Irvine, USA.

- Dr. Elia Saneleuterio, Professor, University of Valencia, Spain.

- Dr. Gleisson R. Schmidt, Professor of Philosophy, Universidade Tecnológica Federal do Paraná, Brazil.

- Dr. Nicholas D. Smith, James F. Miller Professor of Humanities, Lewis and Clark College in Portland, USA.

- Mr. Marco Aurelio da Cruz Souza, Professor \& Choreographer, Regional University of Blumenau (FURB), Brasil, and PhD Candidate, Faculty of Human Kinetics (FMH), Technical University of Lisbon, Portugal.

- $\quad$ Dr. Maria Urma, Professor, University of Art "George Enescu", Romania.

- Dr. Bart Vandenabeele, Academic Member, ATINER \& Professor of Philosophy (Aesthetics \& Philosophy of Art), Ghent University, Belgium.

- Maja Vukadinović, Professor, Higher School of Professional Business Studies, Serbia.

- $\quad$ Dr. Suoqiang Yang, Academic Member, ATINER \& Professor, Chinese Calligraphy 
Department, Director, Institute for Interdisciplinary Research of Calligraphy Art and Information Technology, Xi'anJiaotong University, China.

- Dr. Panayotis Zamaros, Academic Member, ATINER \& Professor, Academic Counsellor, University IFM, Switzerland.

- Dr. John Doerksen, Vice-Provost (Academic Programs \& Students), Western University, Canada.

- Dr. Blaine Garfolo, Chair, Academic Advisory Committee for the DBA Program, Northwestern Polytechnic University, USA.

- Dr. Catie Mihalopoulos, Visiting Professor, Department of Enviroment, California State Polytechnic University, Pomona, USA.

- Dr. Marius-Mircea Crisan, Associate Professor, West University of Timisoara, Romania.

- Dr. Emanuela Ilie, Associate Professor, Faculty of Letters, Alexandru Ioan Cuza University of Iaşi, Romania.

- Dr. Eglè Jaškūnienė, Associate Professor \& Vice-Dean for Science, Faculty of Creative Industries, Vilnius Gediminas Technical University, Lithuania.

- Dr. Nicoleta Calina, Associate Professor, University of Craiova, Romania.

- Dr. Aldo Dinucci, Associate Professor, Federal University of Sergipe, Brazil.

- Dr. Fatma Çelik Kayapinar, Associate Professor, School of Physical Education and Sport, Mehmet Akif Ersoy University, Turkey.

- Dr. Soubhik Chakraborty, Associate Professor, Department of Applied Mathematics, Birla Institute of Technology, India.

- Dr. Caterina Pizanias, Academic Member, ATINER \& Instructor, University of Calgary, Canada.

- Dr. Mariana Cojoc, Academic Member, ATINER \& Associate Professor, Faculty of History \& Political Sciences, Ovidius University, Romania.

- Dr. Sarah L. Cole, Academic Member, ATINER \& Associate Professor, Framingham State University, USA.

- Ms. Jenefer Davies, Associate Professor of Dance, Director of the Dance Program, Washington and Lee University, USA.

- Dr. Christopher Dreisbach, Associate Professor, Johns Hopkins University, USA.

- Dr. Michael Eisman, Academic Member, ATINER \& Associate Professor, Temple University, USA.

- Dr. John Freeman, Academic Member, ATINER, Associate Professor \& Head of Theatre, Falmouth University, UK.

- Dr. Rebecca Gillan, Associate Professor, (RT) Baton Rouge Community College, USA.

- Dr. Ensiye Baqeri, Academic Member, ATINER \& Faculty Member and Assistant Professor, Encyclopedia Islamica Foundation, Iran.

- Dr. Ahmed Ghanem Hafez, Associate Professor, University of Alexandria, Egypt.

- Dr. Sophia Gilmson, Associate Professor of Piano Pedagogy, The University of Texas at Austin, USA.

- Dr.Christian Göbel, Associate Professor of Philosophy, Assumption College, Worcester, USA \&Research Associate, The Von Hügel Institute, St. Edmund's College, University of Cambridge, UK.

- Dr. Ebru Gokdag, Academic Member, ATINER \& Associate Professor, Performing Arts Dept., Anadolu University, Turkey.

- Dr. Samar Mostafa Kamal, Associate Professor, Tourist Guidance Department, Faculty of Tourism \& Hotels, Minia University, Egypt.

- Dr. Yuemin Hou, Academic MEmber, ATINER \& Associate Professor, Institute of Design Engineering, Department of Mechanical Engineering, Tsinghua University, China.

- Dr. Michele Kahn, Associate Professor of Multicultural Education, Studies in Language and Culture, University of Houston-Clear Lake, USA.

- Dr. Douglas J. King, Associate Professor, Gannon University, Department of English, USA. 
- Dr. Simonetta Milli Konewko, Academic Member, ATINER \& Associate Professor, Department of French, Italian, and Comparative Literature, University of Wisconsin Milwaukee, USA.

- Dr. Ana Ktona, Academic Member, ATINER \& Associate Professor, Tirana University, Albania.

- Dr. James Latten, Academic Member, ATINER \& Professor of Music \& Director of Instrumental Music, Juniata College, USA.

- Dr. Gina Marie Lewis, Associate Professor, Art Coordinator, Studio Art, Department of Fine and Performing Arts, Bowie State University USA.

- Dr. Maureen O'Brien, Academic Member, ATINER \& Associate Professor, St. Cloud State University, USA.

- Dr. Margo Apostolos, Academic Member, ATINER, Associate Professor, USC Kaufman School of Dance, \& Co-Director, Cedars-Sinai, USC Glorya Kaufman Dance Medicine Center, University of Southern California, USA.

- Dr. Laura Osterweis, Academic Member, ATINER \& Associate Professor, Communication Arts Department, Framingham State University, USA.

- Dr. Sayyed Rahim Moosavinia, Associate Professor, Shahid Chamran University of Ahvaz, Iran.

- Dr. Georgeta Rata, Associate Professor, B.U.A.S.V.M. Timisoara, Romania.

- Dr. Barbara Sicherl Kafol, Associate Professor of Music Didactis \& Chair of Music, Faculty of Education, University of Ljubljana, Slovenia.

- Dr. Emily Shu-Hui Tsai, Academic Member, ATINER \& Associate Professor, National Chung Hsing University, Taiwan.

- Dr. Nisha Bala Tyagi, Associate Professor, Delhi University, India.

- Dr. Laura Wayth, Associate Professor of Theatre, School of Theatre and Dance, San Francisco State University, USA.

- Dr. Sander Wilkens, Academic Member, ATINER \& Associate Profesor, Berlin University of Technology, Germany.

- $\quad$ Dr. Baruch Whitehead, Academic Member, ATINER \& Associate Professor, Ithaca College School of Music, USA.

- Dr. RajyaShree Yadav, Associate Professor, Goverment R.D. Girls College, India.

- Dr. Barbara Botter, Academic Member, ATINER \& Adjunct Professor, Federal University of Espírito Santo (UFES) - Vitória, Brazil.

- Dr. Fatima Susana Mota Roboredo Amante, Invited Adjunct- Professor, Higher School of Education of Viseu, Portugal.

- Dr. Damian Islas, Invited Profesor, University of Toronto, Canada.

- Dr. Athena Rebecca Axiomakaros, Assistant Professor, Art History, State University of New York - Nassau Community College, USA.

- Dr. Ewa Bobrowska, Academic Member, ATINER \& Assistant Professor of Philosophy and Arts, Academy of Fine Arts in Warsaw, Poland.

- Dr. Tugba Celik, Academic Member, ATINER \& Assistant Professor, Nigde University, Turkey

- Dr. Kathleen Downs, Academic Member, ATINER \& Assistant Professor of Theatre \& Drama, American University of Kuwait, Kuwait.

- Dr. Chrysoula Gitsoulis, Academic Member, ATINER \& Adjunct Assistant Professor, City College, City University of New York, USA.

- Dr. Sinem Elkatip Hatipoğlu, Assistant Professor, Department of Philosophy, Istanbul Sehir University, Turkey.

- Ms. Alma Hoffmann, Academic Member, ATINER \& Assistant Professor, University of South Alabama, USA.

- Dr. Michael James Matthis, Professor \& Director of Philosophy Dept. of English \& Modern Languages, Lamar University, USA. 
- Dr. Vassiliki Kotini, Academic Member, ATINER \& Assistant Professor, Zayed University, UAE.

- Dr. Jamshid Malekpour, Academic Member, ATINER \& Assistant Professor, College of Arts and Sciences, Department of Mass Communications, Gulf University for Science and Technology, Kuwait.

- Dr. Lejla Music, Academic Member, ATINER \& Assistant Professor, Faculty of Political Sciences, University of Sarajevo, Bosnia and Herzegovina.

- $\quad$ Dr. Esra Cagri Mutlu, Academic Member, ATINER \& Assistant Professor, Yuzuncu Yil University. Turkey.

- Dr. Sri Ram Pandeya, Assistant Professor, Ramjas College, University of Delhi, India.

- Dr. Anne Peterson, Assistant Professor, University of Utah, USA.

- Dr. Hany Sallam, Academic Member, ATINER \& Assistant Professor, Theater Department, Faculty of Arts, Alexandria University, \& General Director, National Center for Theater, Ministry of Culture, Cairo, Egypt.

- Dr. Mahdi Shafieyan, Assistant Professor of English Literature \& Islamic Hermeneutics, Imam Sadiq University, Tehran, Iran.

- Dr. Abbasuddin Tapadar, Academic Member, ATINER \& Assistant Professor, Department of English, University of Delhi, India.

- Dr. Mostafa Younesie, Assistant Professor, Tarbiat Modares University, Iran.

- Dr. Deborah S. Nash, Full-Time Philosophy Teacher, Marquette University, USA.

- Mr. Nick Higgett, Principal Lecturer, Digital Design \& Programme Leader, MA Digital Design, De Montfort University, Leicester, UK.

- Dr. Bianca Predoi, Academic Member, ATINER and Architect \& Associate Lecturer, Ion Mincu University of Architecture \& Urbanism, Romania.

- Dr. Eric Francis Eshun, Senior Lecturer, Department of Communication Design, Faculty of Art, College of Art \& Built Environment, Kwame Nkrumah Unversity of Science \& Tech., Kumasi, Ghana.

- Dr. Mike Fox, Senior Lecturer, Limerick School of Art and Design, Ireland.

- Dr. Vasileios Adamidis, Lecturer, Nottingham Trent University, UK.

- Ms. Georgina Gregory, Academic Member, ATINER \& Lecturer, University of Central Lancashire, UK.

- Dr. Siu-lun Lee, 李兆麟, Head of Academic Activities Division \& Senior Lecturer, YaleChina Chinese Language Center, Chinese University of Hong Kong, China.

- Ms. Lillian Nave Goudas, Academic Member, ATINER \& Senior Lecturer, University College, Appalachian State University, USA.

- Dr. Angela McCarthy, Senior Lecturer in Theology, University of Notre Dame Australia, Australia.

- Dr. Joseph Naimo, Senior Lecturer, School of Philosophy and Theology, University of Notre Dame Australia, Australia.

- Dr. Ebunoluwa Olufemi Oduwole, Academic Member, ATINER \& Senior Lecturer, Department of Philosophy, Olabisi Onabanjo University, Nigeria.

- Dr. Daphne Vidanec, Senior Lecturer, Baltazar University of Applied Sciences, Croatia.

- Dr. Doaa Sayed Abdel Azim, Lecturer of English Literature, Faculty of Languages, October University for Modern Sciences and Arts (MSA), Cairo, Egypt.

- Dr. Tsarina Doyle, Academic Member, ATINER \& Lecturer, National University of IrelandGalway, Ireland.

- Dr. Michail Mersinis, Lecturer of Fine Art Photography, the Glasgow School of Art, UK.

- Dr. Orel Beilinson, Academic Member, ATINER \& Lecturer, Harari College Worldwide, USA.

- Dr. Jonas Ciurlionis, Lecturer, Vilniaus University, Lithuania.

- Dr. Nursilah, Lecturer, Department of Dance, Universitas Negeri Jakarta, Indonesia

- Dr. Oseni Taiwo Afisi, Academic Member, ATINER \& Lecturer, Department of Philosophy, 
Faculty of Arts, Lagos State University, Nigeria.

- Dr. Edeh Peter Daniel, Lecturer 1, Department of Philosophy, University of Abuja, Nigeria.

- Dr. Ogunbiyi Olatunde Oyewole, Lecturer, Department of Religions, University of Ilorin, Nigeria.

- Dr. Declan Patrick, Lecturer, Liverpool Hope University, UK.

- Dr. Nur Silah, Lecturer, Dance Department, Negeri Jakarta University, Indonesia.Dr. Stephen Steinberg, Lecturer, University of Pensylavia, USA.

- Dr. Ensa Touray, Academic Member, ATINER \& Lecturer, University of the Gambia, Gambia.

- Dr. Margherita Dore, Adjunct Lecturer in English (Translation Studies), Department of European, American and Intercultural Studies, University of Rome "La Sapienza", Italy.

- Dr. Eleni Tracada, Academic Member, ATINER \& University Principal Tutor in Built Environment, Faculty of Art, Design \& Technology, College of Engineering \& Technology, University of Derby, U.K.

- Dr. Yakup Mohd Rafee, Coordinator, Fine Arts Program, Faculty of Applied and Creative Arts, University Malaysia Sarawak (UNIMAS), Malaysia.

- Dr. Tanja Tolar, Senior Teaching Fellow, School of Oriental and African Studies (SOAS), London, UK.

- Dr. Susana Furphy, Honorary Research Fellow, The University of Queensland, Australia.

- Dr. Alessandra Melas, Postdoctoral Research Fellow, Department of History, Human Sciences and Education, University of Sassari, Italy.

- Dr. Douglas Lucas Kivoi, Researcher/Policy Analyst, the Kenya Institute for Public Policy and Research Analysis (KIPPRA), Kenya.

- Dr. Margot Neger, Academic Member, ATINER \& Postdoctoral Researcher, University of Salzburg, Austria.

- Dr. Sabitha.S.R.Najeeb, M.Phil, Ph.D., University of Dammam, Kingdom of Saudi Arabia.

- Dr. Nasrin Daftarchi, Ph.D. of French Literature, Iran.

- Mr. Sanjit Chakraborty, Research Scholar, Department of Philosophy, Jadavpur University, Kolkata, India.

- Dr. Pritika Nehra, Academic Member, ATINER \& Ph.D Research Scholar, Department of Humanities\& Social Sciences, Indian Institute of Technology, India.

- Mr. Richard Finn, Academic Member, ATINER \& Program Director, Stage and Screen Arts, Whitireia NZ, New Zealand.Dr. Arunima Roychoudhuri, Research Scholar, University of Kalyani, India.

- Dr. Christina Papagiannouli, Academic Member, ATINER \& Research Assistant, Faculty of Creative Industries, University of South Wales, UK.

- Dr. Rossana Raviola, Department of Humanities, Philosophy Section, University of Pavia, Italy.

- Mr. Hugh O'Gorman, Director, Athens Center for Theatre Studies (ACTS) \& Professor and Head of Performance, California State University, Long Beach, USA.

- Ms. Viviana Soler, Academic Member, ATINER \& Research Professional, National Research Council (CONICET) \& Sur National University (UNS), Argentina.

- Ms. Subha Marimuthu, Academic Member, ATINER \& Research Scholar, Bharathi Women's College, India

- Ms. Arunima Roychoudhuri, Academic Member, ATINER \& Full Time Research Scholar, University of Kalyani, India.

- Dr. Inma Garín, University of Valencia, Spain.

- Dr. Manoranjan Mallick, Academic Member, ATINER \& Lecturer, Post-Graduate Department of Philosophy, Utkal University, India.

- Dr. Christina Banalopoulou, PhD Student, University of Maryland, USA.

- Dr. Julijana Zhabeva-Papazova, Academic Member, ATINER \& Musicologist/Independent Scholar, FYROM. 
- Dr. Pablo Villavicencio, PhD in Communication and Semiotics, University PUC-SP (Pontifícia Universidade Católica de São Paulo), Brazil.Mr Mathodi Freddie Motsamayi, $\mathrm{PhD}$ Candidate/Researcher, Centre for Visual Art, University of KwaZulu-Natal, South Africa.

- Mrs. Danielle K. Garrison, MFA Dance Candidate-Aerial Dance Track, University of Colorado-Boulder, Aerialist, Dancer, Choreographer and Teacher, Artistic Director and Founder/DKG Dance, Director of the Student Company and Performer/Frequent Flyers Productions, Inc., Teaching Artist/Colorado Ballet, USA.

- Ms Sandra Philip, Academic Member, ATINER, PhD Candidate \& Associate Lecturer, Edge Hill University, UK.

- Ms. Christine Staudinger, Academic Member, ATINER \& PhD Candidate, University of Vienna, Austria.

- Ms. Raluca-Eugenia Iliou, Academic Member, ATINER \& Doctoral Research Fellow, Brunel University, UK.

- Mrs. Aleksandra Tryniecka, PhD Student, Maria Curie-Skłodowska University, Poland \& Research Fellow, ATINER, Greece.

- $\quad$ Ms. Stephanie Rennick, Teaching Assistant, University of Glasgow, UK.

- Mrs. Tiffany Pounds-Williams, Academic Member, ATINER \& Tufts University, USA.

- Mr. Mark Konewko, Academic Member, ATINER \& Director of Chorus, Marquette University, USA.

- General Managing Editor of all ATINER's Publications: Ms. Afrodete Papanikou

- ICT Managing Editor of all ATINER's Publications: Mr. Kostas Spyropoulos

- Managing Editor of this Journal: Ms. Despina Katzoli (bio)

\section{Reviewers' Board}

Click Here 


\section{President's Message}

All ATINER's publications including its e-journals are open access without any costs (submission, processing, publishing, open access paid by authors, open access paid by readers etc.) and is independent of presentations at any of the many small events (conferences, symposiums, forums, colloquiums, courses, roundtable discussions) organized by ATINER throughout the year and entail significant costs of participating. The intellectual property rights of the submitting papers remain with the author. Before you submit, please make sure your paper meets the basic academic standards, which includes proper English. Some articles will be selected from the numerous papers that have been presented at the various annual international academic conferences organized by the different divisions and units of the Athens Institute for Education and Research. The plethora of papers presented every year will enable the editorial board of each journal to select the best, and in so doing produce a top-quality academic journal. In addition to papers presented, ATINER will encourage the independent submission of papers to be evaluated for publication.

The current issue is the first of the eighth volume of the Athens Journal of Humanities \& Arts (AJHA), published by the Arts, Humanities and Education Division of ATINER.

Gregory T. Papanikos

President

ATINER 


\section{Athens Institute for Education and Research}

\section{A World Association of Academics and Researchers}

\section{$12^{\text {th }}$ Annual International Conference on Visual and Performing Arts 7-10 June 2021, Athens, Greece}

The Arts \& Culture Unit of ATINER is organizing its $\mathbf{1 2}^{\text {th }}$ Annual International Conference on Visual and Performing Arts, 7-10 June 2021, Athens, Greece sponsored by the Athens Journal of Humanities \& Arts. The aim of the conference is to bring together academics and researchers of visual and performing arts, and other related disciplines. You may participate as stream leader, presenter of one paper, chair of a session or observer. Please submit a proposal using the form available (https:/ / www.atiner.gr/2021/FORM-ART.doc).

\section{Academic Members Responsible for the Conference}

- Dr. Stephen Andrew Arbury, Head, Arts \& Culture Unit, ATINER and Professor of Art History, Radford University, USA.

\section{Important Dates}

- Abstract Submission: 8 February 2021

- Acceptance of Abstract: 4 Weeks after Submission

- Submission of Paper: 10 May 2021

\section{Social and Educational Program}

The Social Program Emphasizes the Educational Aspect of the Academic Meetings of Atiner.

- Greek Night Entertainment (This is the official dinner of the conference)

- Athens Sightseeing: Old and New-An Educational Urban Walk

- Social Dinner

- Mycenae Visit

- Exploration of the Aegean Islands

- Delphi Visit

- Ancient Corinth and Cape Sounion

\section{Conference Fees}

Conference fees vary from $400 €$ to $2000 €$

Details can be found at: https://www.atiner.gr/2021fees 


\section{Athens Institute for Education and Research}

A World Association of Academics and Researchers

\section{$6^{\text {th }}$ Annual International Symposium on Religion \& Theology \\ 24-27 May 2021, Athens, Greece}

The Humanities \& Education Division of ATINER is organizing its $\mathbf{6}^{\text {th }}$ Annual International Symposium on Religion \& Theology, 24-27 May 2021, Athens, Greece. The aim of the conference is to bring together academics and researchers of Religion, Theology and other related disciplines. You may participate as stream leader, presenter of one paper, chair of a session or observer. Please submit a proposal using the form available (https:/ / www.atiner.gr/2021/FORM-REL.doc).

\section{Important Dates}

- Abstract Submission: 25 January 2021

- Acceptance of Abstract: 4 Weeks after Submission

- Submission of Paper: 26 April 2021

\section{Academic Member Responsible for the Conference}

- Dr. William O'Meara, Academic Member, ATINER \& Professor, Department of Philosophy and Religion, James Madison University, USA.

\section{Social and Educational Program}

The Social Program Emphasizes the Educational Aspect of the Academic Meetings of Atiner.

- Greek Night Entertainment (This is the official dinner of the conference)

- Athens Sightseeing: Old and New-An Educational Urban Walk

- Social Dinner

- Mycenae Visit

- Exploration of the Aegean Islands

- Delphi Visit

- Ancient Corinth and Cape Sounion

More information can be found here: https://www.atiner.gr/social-program

\section{Conference Fees}

Conference fees vary from $400 €$ to $2000 €$ Details can be found at: https://www.atiner.gr/2021fees 


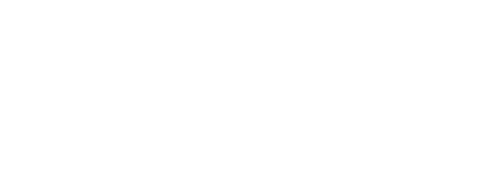




\title{
Globalism in Medieval Literature? Pre-Modern Perspectives in Poetic Projections: Wolfram von Eschenbach's Parzival, Konrad Fleck's Flore und Blancheflor, and Reinfried von Braunschweig
}

\author{
By Albrecht Classen
}

\begin{abstract}
This paper examines globalism in the pre-modern world as reflected in literary texts. In contrast to globalization, globalism indicates an opening of perspectives toward distant parts of the world and embracing to some extent the foreign people and their cultures as, relatively speaking, equals, more or less approaching the concept of transculturality. Whereas the European Middle Ages have commonly been identified as xenophobic, determined by fear, and parochial, many literary documents reflect a rather open-minded perspective and undermine such stereotypical judgments. Undoubtedly, of course, the paradigm of Christianity ruled strongly, but within the field of literary imagination, we can discover numerous examples of European protagonists openly, fairly, respectfully, and even lovingly interacting with people in the East and elsewhere. We might face here nothing but fictional projections, but those were obviously widely enjoyed by the contemporary audiences and so must have had a considerable impact on the readers/listeners. The examples chosen for this analysis are Wolfram von Eschenbach's Parzival, Konrad Fleck's Flore und Blanscheflur, and the anonymous Reinfried von Braunschweig.
\end{abstract}

\section{Globalism avant la letter}

If anything might convince us to approach human history and culture from a global perspective, then the current global crisis with the COVID-19 virus and its enormous impact on people across the globe (2020). Previous epidemics and pandemics have also wreaked havoc on humanity, not to speak of huge events in natural history, with tsunamis, volcanoes, earthquakes, heat waves, and climate changes which have also deeply affected everyone on the entire globe. ${ }^{1}$ For instance, recent scholars have increasingly pointed to epidemics as much more relevant causes for the devastating decline and eventual fall of the Western Roman Empire than the incursions of the various Germanic peoples or political

\footnotetext{
*University Distinguished Professor, University of Arizona, USA.

1. R. S. Bray, Armies of Pestilence: The Effects of Pandemics on History (Cambridge: Lutterworth Press, 1996); Mark D. Hardt, History of Infectious Disease Pandemics in Urban Societies (Lanham, MD, Boulder, CO, New York, and London: Lexington Books, 2016); The Routledge History of Disease, ed. Mark Jackson. The Routledge Histories (London and New York: Routledge, Taylor \& Francis, 2017).
} 
and military conflicts in the interior. ${ }^{2}$ The black death in the middle of the fourteenth century came from Tibet, made its way across the Himalayas, down to India, from there it marched, literally, westward, reaching the Black Sea, and was then transported to Genoa and Venice, whereupon all of Europe was affected. ${ }^{3}$ In fact, throughout history, global natural events (medical or physical) have exerted a huge influence, even if the individual often could not comprehend the events beyond the parochial limits. In light of these past and present developments, we are certainly called upon as cultural historians to pursue much more global perspectives than ever before, as difficult as this often proves to be out of many different limitations due to our narrow disciplinary foci, lack of linguistic competence, and our common concentration on smaller geographic regions. ${ }^{4}$

Global history, however, as challenging and difficult as it certainly proves to be, deserves much more of our attention so that we can recognize the much larger perspectives developed by poets, artists, philosophers, merchants, and others long before the modern age..$^{5}$ In fact, we are today the avatars of developments that had set in already in antiquity and the Middle Ages, which means that the exploration of this topic can help us understand much better not only the past, but the true meaning of the way how human society has been operating throughout the ages and what we might expect in the future. This paper thus intends to develop early inroads into the world of high and late medieval (German) literature created in Europe which had already developed some types of globalism. At least, some poets demonstrated a certain knowledge about distant lands and even entire continents that allow us to argue that they were

2. Plague and the End of Antiquity: The Pandemic of 541-750, ed. Lester K. Little (Cambridge: Cambridge University Press, 2007). See also J. N. Hays, The Burdens of Disease: Epidemics and Human Response in Western History (2009; New Brunswick, NJ: Rutgers University Press, 2009); L' impatto della "peste antonina": quinto degli Incontri capresi di Storia dell'Economia Antica, ed. Elio Lo Cascio (Bari: Edipuglia, 2012); Kyle Harper, The Fate of Rome: Climate, Disease, and the End of an Empire. The Princeton History of the Ancient World (Princeton, NJ, and Oxford: Princeton University Press, 2017); Kay Peter Jankrift, Im Angesicht der "Pestilenz": Seuchen in westfälischen und rheinischen Städten (1349-1600) (Stuttgart: Franz Steiner Verlag, 2020).

3. Pandemic Disease in the Medieval World: Rethinking the Black Death, ed. Monica Green (Leeds: Arc Humanities Press, 2015); Epidemien und Pandemien in historischer Perspektive, ed. Jörg Vögele, Stefanie Knöll, and Thorsten Noack. Neuere Medizin- und Wissenschaftsgeschichte (Wiesbaden: Springer VS, 2016).

4. The Oxford Handbook of Global Studies, ed. Mark Juergensmeyer, Saskia Sassen, and Manfred B. Steger; managing ed. Victor Faessel (New York: Oxford University Press, 2019).

5. Many recent efforts in that regard have not been very convincing, such as The Greenwood Encyclopedia of Global Medieval Life and Culture, ed. Joyce E. Salisbury. 3 vols (Westport, CT, and London: Greenwood Press, 2009), because they simply include nonEuropean continents and create a rather disjointed narrative fabric with many threads that do not intertwine. Granted, this leads to a deconstruction of Euro-centrism, but it does not construct a really meaningful concept for future historians. 
early participants in a global discourse, accepting the foreign cultures and peoples as more or less equal partners within their own medieval frame of mind, whether in realistic or just imaginary terms.

We know, of course, already of many medieval and early modern travelers who covered enormous distances particularly far into the Middle and the Far East, particularly China (Marco Polo, Odorico da Pordenone, John of Pian de Carpine, etc.). Reversely, Arab travelers such as Ibn Fadlan and Ibn Battuta explored many non-Muslim countries both in eastern Europe and in Asia. In the late Middle Ages, the number of Christian pilgrims grew exponentially, and many of them explored also other regions beyond the Holy Land. ${ }^{6}$ To what extent did they establish the foundation for a global perspective, if at all? Was there any intellectual, political, or commercial exchange? After all, how much does any traveler really perceive, and what types of communication develop during his/her journey? These are questions of great relevance for us today as well because global tourism, for instance, does not create globalism, whereas the organization "Doctors without Borders" certainly does. ${ }^{7}$

Late medieval translators such as Antonius von Pforr demonstrated that they were surprisingly aware about foreign cultures, literature, and philosophy and can today be identified as precursors of what we might call 'transculturality' today. ${ }^{8}$ Hence, there is no doubt that we can and must explore the meaning of

6. See the contributions to Encyclopedia of Medieval Pilgrimage, ed. Larissa J. Tayor, Leigh Ann Craig, et al. (Leiden and Boston: Brill, 2010); for larger issues, see the contributions to East Meets West in the Middle Ages and Early Modern Times: Transcultural Experiences in the Premodern World, ed. Albrecht Classen. Fundamentals of Medieval and Early Modern Culture, 14 (Berlin and Boston: Walter de Gruyter, 2013); and to Travel, Time, and Space in the Middle Ages and Early Modern Time: Explorations of Worldly Perceptions and Processes of Identity Formation, ed. Albrecht Classen. Fundamentals of Medieval and Early Modern Culture, 22 (Berlin and Boston: Walter de Gruyter, 2018). See also Europe: A Literary History, 1348-1418, ed. David Wallace. 2 vols. (Oxford: Oxford University Press, 2016); to L'expérience des frontières et les littératures de l'Europe Médiévale, ed. Sofia Lodén and Vanessa Obry. Colloques congres conference moyen âge, 26 (Paris: Éditions Honoré Champion, 2019). Cf. also Joyce E. Salisbury, "Europe," The Greenwood Encyclopedia of Global Medieval Life and Culture (Westport, CT, and London: Greenwood Press, 2009), 1-178, with a focus on "Global Ties" (69-77); Michael Borgolte, "Kommunikation Handel, Kunst und Wissenstausch," Weltdeutungen und Weltreligionen 600 bis 1500, ed. Johannes Fried and Ernst-Dieter Hehl. WBG Welt-Geschichte, III (Darmstadt: Wissenschaftliche Buchgesellschaft, 2010), 17-144. See also the informative study by Pedro Martínez García, El cara a cara con el otro: la visión de lo ajeno a fines de la Edad Media y comienzos de la Edad Moderna a través del viaje (Frankfurt a. M.: Peter Lang, 2015).

7. https://www.doctorswithoutborders.org/ (last accessed on March 26, 2020). Fortunately, there are many other global organizations that work hard to improve the lives of people across the globe.

8. Albrecht Classen, "India, Persia, and Arabia in the Mind of a Late Fifteenth-Century German Author: Transcultural Experiences through the Literary Discourse. Antonius von 
globalism as it emerged already in the pre-modern age in order to comprehend more appropriately how people in the Middle Ages viewed the foreign world beyond the common dimensions set up primarily by the Christian Church and were prepared, at least mentally, to acknowledge other cultures, peoples, religions, and languages. ${ }^{9}$ To be sure, they were not at all as myopic or narrowminded as many modern studies seem to indicate, and there are numerous indications that medieval poets were actually more prepared to explore exotic countries and cultures especially to the East, than we might have assumed previously. Studying their fictional projections regarding the global dimension of the realm where their protagonists operated sheds not only better light on their texts and messages, it also lays the foundation for a more complex, historically and literarily grounded analysis of globalism in past and present.

Following Sebastian Conrad, we can postulate that "Global history can shift our attention to the hierarchies of power and the geopolitical structures that conditioned the way in which the world became integrated with important effects on individuals, groups, and whole societies." ${ }^{10}$ However, most scholars working on the history of globalism take as their starting point the sixteenth century, and ignore that many medieval writers had already demonstrated a strong interest in opening their perspectives toward the world beyond western Europe, Christianity, and the latinitas. ${ }^{11}$ Conrad grants that "no society can be fully understood in isolation" (101), and he highlights, above all, the economic networks that existed in many parts of the world throughout time (103-04), and also alerts us to the complexity of global structures (108). He is certainly willing to incorporate the Middle Ages into the discourse on globalism (111), but the actual task of figuring out what that really entails still remains to be done.

There are at least three possible avenues to explore the issue at stake here. Recent scholars have returned to the topic of world literature and have endeavored to study the most diverse texts from all over the world composed at

Pforr and his Buch der Beispiele der Alten Weisen," Philological Quarterly 99, no. 2 (2020): 11945.

9. Meeting the Foreign in the Middle Ages, ed. Albrecht Classen (New York and London: Routledge, 2002).

10. Sebastian Conrad, What is Global History? (Princeton, NJ: Princeton University Press, 2016), 214.

11. For early corrective approaches, see Geraldine Heng and Lynne Ramey, "Early Globalities, Global Literatures: Introducing a Special Issue on the Global Middle Ages," Literature Compass (2014): 1-6; online at: 10.1111/lic3.12156 (last accessed on March 26, 2020); Geraldine Heng, "Reinventing Race, Colonization, and Globalisms across Deep Time: Lessons from the Longue Durée," in PMLA 130.2 (2015), 358-66; eadem, "Early Globalities, and Its Questions, Objectives, and Methods: An Inquiry into the State of Theory and Critique," in Exemplaria 26.2-3 (2014), 232-51; Naomi Standen and Monica White, "Structural Mobilities in the Global Middle Ages," in Past \& Present 238, suppl. 13 (2018), $158-89$. 
more or less the same time, whether influencing each other or not. Parallel to this, historians have tried to develop global history, equally a murky concept. This approach, however, leads to a very loose narrative fabric with many threads that do not really intertwine or interact with each other. ${ }^{12}$ Another approach would be to examine the vast world of pilgrimage and other travelogues that certainly confirm how much late medieval Europe was on the road and explored many neighboring countries. ${ }^{13}$ The third avenue, which I want to pursue here in light of three representative cases, relies on the theoretical model of the history of mentality and takes into account literary and art-historical works as mirrors of fundamental attitudes, ideas, sentiments, and feelings. ${ }^{14}$ Even though these sources are not as reliable and concrete as medieval maps, letters, journals, and other ego-documents, they provide a deep and meaningful insight into the mental structure prevalent at a certain time insofar as they reflect what poets and their audiences imagined as possible and feasible.

All this does not mean that actual conversations across linguistic and cultural divides took place, though those might certainly have been possible considering the freedom and flexibility of most poets who commonly commanded a high linguistic level. Most importantly for us, the main fictional discourse provided more often than we might have thought possible an imaginary roadmap for intercultural exchanges, early attempts to conceive of interreligious dialogue, and for intellectual engagements with foreign lands and people. ${ }^{15}$

12. A Companion to World Literature. Vol. 2: 601 CE to 1450. Gen. ed.: Ken Seigneurie, vol. ed.: Christine Chism (Chichester, West Sussex: John Wiley \& Sons, 2020).

13. Trade, Travel, and Exploration in the Middle Ages: An Encyclopedia, ed. John Block friedman and Kristen Mossler Figg (New York and London: Garland, 2000); Philippe Beaujard, From the Seventh Century to the Fifteenth Century CE, trans. ed. Tamara Loring, Frances Meadows, and Andromeda Tait. Mondes de l'ocean Indien, 2 (Cambridge: Cambridge University Press, 2019); The Practice of Global History: European Perspectives, ed. Matthias Middell (London, New York, et al.: Bloomsbury Academic, 2019); Roland Wenzlhuemer, Doing Global History: An Introduction in Six Concepts (London: Bloomsbury Academic, 2020).

14. Europäische Mentalitätsgeschichte: Hauptthemen in Einzeldarstellungen, ed. Peter Dinzelbacher. 2nd revised and expanded ed. (1993; Stuttgart: Alfred Kröner Verlag, 2008). See here especially the section "Das Fremde und das Eigene" (459-518).

15. La Raison du merveilleux à la fin du Moyen Âge et dans la première modernité: Textes et images, ed. Dominique de Courcelles. Rencontres, 399 (Paris: Classiques Garnier, 2019)); Albrecht Classen, Religious Toleration in the Middle Ages and Early Modern Age: An Anthology of Literary, Theological, and Philosophical Texts (Berlin: Peter Lang, 2020). See now the contributions to Imagination and Fantasy in the Middle Ages and Early Modern Time: Projections, Dreams, Monsters, and Illusions, ed. Albrecht Classen. Fundamentals of Medieval and Early Modern Culture, 24 (Berlin and Boston: Walter de Gruyter, forthcoming [2020]). 


\section{Literary Examples of Medieval Globalism}

For my analysis, here I have chosen three texts from the history of medieval German literature where the experience of the distant East plays a major role and underscores explicitly how much the poets and hence their audiences were aware of and interested in the foreign world far beyond even the Mediterranean: Wolfram von Eschenbach's Parzival (ca. 1205); Konrad Fleck's Flore und Blanscheflur (ca. 1220), and the anonymous Reinfried von Braunschweig (after 1291). All three texts reflect a broader European interest in the Asian cultures and present a variety of innovative perspectives that lend themselves surprisingly well for the exploration of globalism already in the Middle Ages. Each time, we observe that the protagonist travels far beyond the traditional European limits in geographical terms and enjoys surprisingly good experiences that we might characterize today as 'transcultural.' Wolfram's work was in part based on Chrétien de Troyes's Perceval, and Fleck's romance was one of countless other versions of the same literary material highly popular throughout medieval Europe. Only Reinfried appears to have exerted very little success, having survived only anonymously and in one manuscript (Gotha, Forschungsbibliothek der Universität Erfurt, Cod. Memb. II 42). Nevertheless, here we come across yet another fascinating example of personal encounters of two individuals representing East and West who deliberately dismiss previous stereotypes and prejudices and join hands in their touristic interests and simple curiosity.

We need to keep in mind that medieval Europe was deeply determined by the paradigm of the Christian religion. Everything else was anathema. However, the Church could not dominate or control secular literature, or every piece of the art works produced for private patrons. The nobility pursued quite different interests than the ecclesiastics preferred, and the same applied to the urban audiences and writers. Drawing from just three medieval texts might not provide us with a solid base to address the larger framework, which was certainly Eurocentric. I would submit, however, that these three works can be regarded as representative of larger mental-historical conditions, especially in the case of Fleck's romance.

Reinfried von Braunschweig was composed at a time when many other poets also reflected on the changing fortunes of the Crusades and integrated rather open-minded perspectives toward other cultures and religions. ${ }^{16}$ Wolfram's Parzival experienced a tremendous popularity as

16. Albrecht Classen, Tolerance in the Middle Ages? The Good Heathens as Fellow Beings in the World of Reinfried von Braunschweig, Konrad von Würzburg's Partonopier und 
documented by the large number of extant manuscripts containing the text, and so it seems natural that some of his arguments must have rattled common assumptions and religious concepts. ${ }^{17}$ Thematically and generically, these three texts differ considerably from each other, Wolfram's being a grail romance, Fleck's being a sentimental romance, and Reinfried being a crusading romance, but they all share to a considerable extent a certain level of curiosity about and interest in distant lands, without repeating the traditional absolutist position held by most of their contemporaries vis-à-vis non-Christians and non-Europeans. The three authors project, as I will outline below, a certain sense of openmindedness and explicitly entertained the notion that their protagonists could be welcome in the East and operate there successfully, if not vice versa as well. To what extent we can talk here actually about 'transculturality,' or rather 'interculturality,' or even about 'globalism,' will have to be examined at the end through a comparative analysis.

Granted, all three poets addressed primarily a German-speaking audience and did not even imagine that they might create an actual conversation with Asian or non-Christian contemporaries. However, as we will observe, in each case just this situation is presented in rather dramatic terms, inviting us to recognize that the thirteenth century might have witnessed a considerable paradigm shift that allowed global perspectives to enter the picture. ${ }^{18}$ In each case, historical conditions do no really concern us, and there are not even reflections of the imminent fall of Acre in 1291 to the Muslims, which dramatically changed the entire European and Middle Eastern relationship (with a slight exception in Reinfried). Nevertheless, here we face a remarkable ensemble of literary works in which the European Christian protagonists long before the coming of the modern age establish meaningful relationships with individuals in the East, as undefined as that geographic term might be.

Both Wolfram's Parzival and Fleck's Flore und Blanscheflur have already been discussed from many different perspectives; the situation is quite different with Reinfried, but by focusing on the issue of globalism, I hope to unearth significant parallels among all three texts and to connect

Meliur, and Die Heideninne," in Amsterdamer Beiträge zur älteren Germanistik 61 (2006), 183-223.

17. http://www.handschriftencensus.de/werke/437; here are listed 88 manuscripts, and one incunabulum from 1477 is also mentioned. See also Bernd Schirok, "Die Handschriften und die Entwicklung des Texts," Wolfram von Eschenbach: Ein Handbuch, ed. Joachim Heinzle. Vol. I: Autor, Werk, Wirkung (Berlin and Boston: Walter de Gruyter, 2011), 308-34.

18. Laura J. Whatley, "Shifting Paradigms of Place and Ritual on Crusader Seals Before and After the Fall of Acre in 1291," in Paradigm Shifts during the Global Middle Ages and the Renaissance, ed. Albrecht Classen. Arizona Studies in the Middle Ages and the Renaissance, 44 (Turnhout: Brepols, 2019), 43-63. 
them meaningfully with the current discourse on globalism as it concerns us today. ${ }^{19}$ The reason why all this matters so much is grounded in the literary character of those works making it possible to imagine novel worlds. Undoubtedly, that places them within the realm of fictionality, but these poets projected, with their narratives, highly intriguing scenarios in which Christian Europeans encountered and interacted with people in western Asia and even elsewhere on a refreshingly personal level. Those scenarios were thus presented to many different audiences, which in turn were thus accustomed to new, that is, virtually global concepts connecting their own little communities with countries and people far beyond their actual and concrete reach.

As Shayne Aaron Legassie has recently pointed out, "In contrast to Grosseteste, many other late medieval voices lauded their age as one marked by unprecedented advances in geographical knowledge," which he then backs up convincingly with references to numerous authors from the fourteenth and fifteenth centuries. ${ }^{20}$ Considering the booming trade during the late Middle Ages and the early modern age closely connecting Europe with the neighboring and further distant countries, ${ }^{21}$ it does not come as a surprise that contemporary poets were well positioned either as harbinger or as mirrors of this opening up of the mind, such as in the case of Rudolf von Ems's Der Guote Gerhard (ca. 1220).22 Marco Polo and then John Mandeville several decades later both excited their audiences about the Oriental world they had toured or at least dreamed about as in the case of the latter, and provided thereby the additional layer of narrative preparedness to accept the world in its more global dimensions. ${ }^{23}$

19. Granted, in the Companion of World Literature, Wolfram is represented through one contribution (2,967-76), but neither Fleck nor Reinfried were considered here at all.

20. Shayne Aaron Legassie, The Medieval Invention of Travel (Chicago and London: The University of Chicago Press, 2017), 61, and passim.

21. Arturo Giraldez, The Age of Trade: The Manila Galleons and the Dawn of the Global Economy. Exploring World History (Lanham, MD, Boulder, CO, et al.: Rowman \& Littlefield, 2015); he focuses, however, mostly on the time past 1500.

22. Albrecht Classen, An English Translation of Rudolf von Ems's Der guote Gêrhart (Newcastle upon Tyne: Cambridge Scholars Press, 2016); id., "The Transnational and the Transcultural in Medieval German Literature: Spatial Identity and Pre-Modern Concepts of Nationhood in the Works of Wolfram von Eschenbach, Gottfried von Straßburg, Rudolf von Ems, and Konrad von Würzburg," in Mediaevistik 29 (2016), 175-94; id., "Medieval Transculturality in the Mediterranean from a Literary-Historical Perspective: The Case of Rudolf von Ems's Der guote Gêrhart (ca. 1220-ca. 1250),"in Journal of Transcultural Medieval Studies 5.1 (2018), 133-60.

23. Often, recent studies use similar terms but do not engage with the real issue at stake; see, for instance, Rolf Darge, "Wahre Welt: Die Welt als offenes Beziehungsfeld des menschlichen Geistes im mittelalterlichen Denken," in Welterfahrung und Welterschließung 


\section{Wolfram von Eschenbach's Parzival}

Wolfram von Eschenbach would not need to be introduced here once again. ${ }^{24}$ Suffices it to summarize that he created one of the most important grail romances in the Middle Ages, his Parzival, in part based on Chrétien's model, his Perceval. He also composed a major crusading epic, Willehalm, the fragmentary Titurel, and some dawn songs. In Parzival, the author made serious efforts to develop a more global perspective by presenting to us first Gahmuret's adventures in the distant East, and later, the life of his son Parzival, who will later confront his half-brother, Feirefiz..$^{25}$ The fictional framework allowed Wolfram to play with various concepts that must have been quite radical at his time, critically undermining the Christian and the European paradigm and giving credit to the world to the East as well, and this just at a time when the Fourth Crusade in 1204 ended with the conquest of Constantinople and its horrible plunder by the Christian armies. It would be hard to imagine how the Europeans must have reacted to the news of the badly redirected Crusade, which had exposed much of the hypocrisy of the entire crusading mentality. ${ }^{26}$ Yet, Wolfram did not voice any comments critical of the entire business with crusading. However, in his Parzival he suggested surprisingly innovative concepts about how people from East and West could interact with each other.

As Wolfram scholars have often pointed out, the life of Gahmuret takes on a rather unusual tangential, even for a fictional medieval knight, because he soon finds himself in the service of the lord of Babylon, and performs military wonders for him, earning him greatest respect among friends and foe in that distant country. There is not one bit of curiosity about the foreign culture and

in Mittelalter und Früher Neuzeit, ed. Anna Kathrin Bleuler. Interdisziplinäre Beiträge zu Mittelalter und Früher Neuzeit, 5 (Heidelberg: Universitätsverlag Winter, 2016), $25-45$.

24. Most recently, Evelyn Meyer, "Wolfram von Eschenbach's Parzival: A Complex Reshaping and Expansion of a Source," in Seigneurie, Ken et al. (ed.), A Companion to World Literature, vol. 2, 967-77. For the most authoritative critical study, though, see Joachim Bumke, Wolfram von Eschenbach. Sammlung Metzler, 36. 8th, completely rev. ed. (1964; Stuttgart: Metzler, 2004).

25. Wolfram von Eschenbach, Parzival. Studienausgabe. 2nd ed. Mittelhochdeutscher Text nach der sechsten Ausgabe von Karl Lachmann. Übersetzung von Peter Knecht (Berlin and New York: Walter de Gruyter, 1998); for a convenient introduction, see Heiko Hartmann, Einführung in das Werk Wolframs von Eschenbach. Einführung Germanistik (Darmstadt: Wissenschaftliche Buchgesellschaft, 2015). There are many good English translations of Wolfram's Parzival, but here I offer my own. See also Heiko Hartmann, Einführung in das Werk Wolframs von Eschenbach. Einführung Germanistik (Darmstadt: Wissenschaftliche Buchgesellschaft, 2015).

26. See, for instance, David M. Perry, Sacred Plunder: Venice and the Aftermath of the Fourth Crusade (University Park, PA: Pennsylvania State University Press, 2015); George E. Demacopoulos, Colonizing Christianity: Greek and Latin Religious Identity in the Era of the Fourth Crusade (New York: Fordham University Press, 2019). 
different religion. Chivalric values predominate there as well, and Gahmuret is never concerned with maintaining his own standing and status in the Islamic world because he enjoys greatest esteem as a knight there and feels completely at home in the East.

First, this young man hears rumors of the mighty ruler Baruch who controls two thirds of the entire earth. This empire of Balduc thus constitutes a much wider and more impressive national entity than anyone could imagine in medieval Europe. The poet does not define in detail what regions belonged to Baruch, or what languages were spoken there, although he makes clear that Balduc was not Christian and hence outside of the influence sphere of Christianity within Europe. In order to help his readers/listeners understand the full extent of this empire, and the degree to which Baruch commands complete control over his people, the narrator underscores that many crowned kings served under him and that the ruler himself enjoyed the parallel authority as the pope does in the western world (8). We also hear of Baruch's two brothers, Pompey and Ipomidon from whom he had taken away Nineveh, an ancient Assyrian city of Upper Mesopotamia, today near Mosul in Iraq. We do not need to probe further how much Wolfram really understood the historical and cultural connotations since it suffices for us that he simply projected a huge world far to the East where unexpected and quite different power structures dominate. ${ }^{27}$ However, in strong contrast to all other real western travelers getting into that mostly unknown world, Gahmuret is happily welcomed and immediately recognized as a major fighter of great use for Baruch because no other man can withstand his force (9).

But Gahmuret does not stay there for long, instead he moves soon to the kingdom of Zazamanc, inhabited by a black-skinned people. Their queen Belacane is besieged by two armies, and she has no defender left, when this stranger appears and soon volunteers as her champion, defeating all of her opponents. Although he at first feels repulsed by Belacane's blackness, he then actually falls in love with her and joins with her in a kind of marriage, from which results a son, Feirefiz, whom Gahmuret never meets in person because he abandons his wife before the delivery of the baby, and he later dies in battle.

Two major aspects characterize the entire episode; on the one hand, Gahmuret is swept away by his erotic desires for the queen and entirely disregards the differences in their skin colors. Even though he later claims in a letter to her that he had to leave her because she was not a Christian, this proves to be nothing but a lie. He would have happily stayed there in

27. Alfred Raucheisen, Orient und Abendland: ethisch-moralische Aspekte in Wolframs Epen "Parzival" und "Willehalm". Bremer Beiträge zur Literatur- und Ideengeschichte, 17 (Frankfurt a. M. and New York: Peter Lang, 1997); Debra N. Prager, Orienting the Self: The German Literary Encounter with the Eastern Other. Studies in German Literature, Linguistics, and Culture (Rochester, NY: Camden House, 2014). 
marriage with Belacane if he only had had more opportunities for knightly combat and glory. On the other, the knights fighting outside of the castle represent a motley of aristocrats from all over Europe and the Eastern world, so Gahmuret's own turning to Baruch was regarded as nothing exceptional, except for the extraordinary fame which this Oriental ruler enjoyed. For Wolfram, knighthood and courtly love were globally shared values, and he entrusted the neighbors to the east of Europe as being on the same social, ethical, and knightly level as they were. As to the love relationship, we only need to listen to the following passage to be convinced that our poet harbored no particular concerns about racial differences: "The black Mooress, that country's queen, caused him to swoon again and again. He twisted and turned, time and again, like a bundle of willow twigs, his joints cracking. Battle and love were his desire" (16-17). ${ }^{28}$

Of course, just as in his subsequent epic poem, Willehalm (ca. 1219), the Christian hero defeats even the best heathen warriors, but those are certainly portrayed as most worthy and noble character, such as the prince Razalic. "Not for a single day did he desist, that mightiest man of Azagouc - his heritage did not betray him, his lineage was of kingly fruit - but he always headed off to joust before the city" (19). For Gahmuret, any noble opponent in front of him proves to be a worthy goal, and he is exceedingly happy with his successes in the Oriental lands, though he later returns to Europe because peace has been achieved due to Gahmuret's own victories. He later claims to Belacane that the difference in their religion drove him away from her, but the letter which he leaves behind for her, easily reveals to be deceptive because this knight simply searches for ever new manly adventures and accepts them as they come his way, whether he is in the West or in the East (25).

Gahmuret turns west from there and eventually becomes Queen Herzeloyde's husband, but he does not stay long with her and leaves her, as in the previous case, before she can deliver their son, Parzival. As scholars have often observed, Gahmuret proves to be a highly unstable character who knows no limits in this world and roams the earth constantly on the search for knighthood. ${ }^{29} \mathrm{He}$ is open to love and welcomes women's invitations, but he heart is really only set on manly deeds, and this wherever he can find them. He does not harbor any religious dogmas and only looks for equals among the class of high-ranking knights, wherever he can find them anywhere in the world.

28. Andreas Mielke, Nigra sum et formosa: Afrikanerinnen in der deutschen Literatur des Mittelalters; Texte und Kontexte zum Bild des Afrikaners in der literarischen Imagologie. HelfantTexte, 11 (Stuttgart: Helfant Ed., 1992).

29. David F. Tinsley, "Mapping the Muslims: Images of Islam in Middle High German Literature of the Thirteenth Century," in Contextualizing the Muslim Other in Medieval Christian Discourse, ed. Jerold C. Frakes. The New Middle Ages (New York: Palgrave Macmillan, 2011), 65-101; here 81-89. 
Not surprisingly, when he takes his leave from Herzeloyde, he returns directly to the service for Baruch, as if he cannot stay away from the East. And correspondingly, "He was welcomed with joy" (44). However, tragedy then strikes because an evil-minded person, in this case a heathen, pours blood of a he-goat on Gahmuret's diamond helmet which softens it entirely, and this then later means his death in battle. Yet, the poet does not use this as an opportunity to return to the traditional xenophobic attitudes of his contemporaries; instead, he describes in great detail how much the Baruch and his court grieve the death of this noble man and endeavor to provide a worthy burial for him. Not only is his corpse embalmed, as was expected for a noble dead, but the noble warrior receives a most precious burial site, a setting which speaks volume regarding the mutual respect which those men had felt for each other. They go even so far as to place a cross on his grave "for his solace, to shelter his soul" (46). The narrator makes sure, of course, to alert his audience about the vast superiority of a Christian burial and the Christian faith, but he does not fail to point out a rather surprising epitaph in which they honor both him in his knightly accomplishments and also his own religion: "He bore baptism and Christian faith. His death grieved Saracensthat is no lie, but the truth" (47), and: "He had won the victory over falsity. Now wish salvation to him who lies here" (47).

We have to acknowledge that Wolfram could not or did not want to undermine the dominant paradigm of the Christian faith being the only true one, but within his fictional setting he certainly went so far as to project the court of Baruch as a place of highest ethical esteem attractive even for the best European knights. That ruler receives the narrator's great praise and respect, although there is no attempt at all to preach, to missionize, to convert, or to baptize. In fact, as Joachim Bumke had already pointed out, Wolfram projected here a surprisingly realistic scenery where Gahmuret is extremely effective as a champion for the Baruch in his struggle against the Egyptian Babylon, and this in clear contrast to the situation in works such as Herzog Ernst or Priest Lambrecht's Alexander. ${ }^{30}$

Gahmuret simply accepts that the Middle East is one of the best battle grounds for him where he can also experience deep love. Surprisingly, in that context we have to consider that both women, the black Queen Belacane, and the white Queen Herzeloyde suffer the same destiny, falling in love with this unreliable man, conceiving a son with him, and being abandoned by him afterwards. Knightly virtues and honor do not know any national, racial, ethnic, or even religious limits. For Wolfram, moreover, those ethical values are not limited to Europe; and instead he argues explicitly that humanity

30. Bumke, Wolfram von Eschenbach (see note 24), 46. 
consists of a large family, globally. ${ }^{31}$

At the end of Parzival, this finds additional confirmation when the eponymous protagonist encounters his half-brother Feirefiz and fights with him at first because he does not recognize him. Only when Parzival's sword breaks, the stranger also puts his weapon away; both take a break and soon recognize each other as half-brothers, and thus they overcome any possible military conflict between each other. The situation soon becomes a little ironic because Feirefiz is allowed to accompany Parzival to the Grail where the latter has to ask his uncle Anfortas the decisive question (333), reflecting his empathy for the suffering king, which then solves all problems and returns happiness to the world, especially at the court of Munsalvæsche. Feirefiz does not understand much what is going on because he is a heathen, hence not baptized, but he quickly accepts the Christian faith for pragmatic reasons, jumps in the baptism font, and is then allowed, as a new Christian, to marry one of the Grail maids, Repansche de Schoye. His carelessness and irreverence toward the religious ceremonies make the members of the Grail court laugh in happiness; they are actually relaxed and do not care much about the stringencies of the Christian religion. As long as he would denounce his old gods and his beloved in the distant land, Secundille, Feirefiz would be perfectly qualified to join the Grail community and be allowed to join hands with Repansche (341).

Subsequently, the newly-wed couple departs and returns to the world which we localize Iraq or Iran, if not India, where Feirefiz establishes Christianity and where Repanse delivers a son, the future Prester John, the well-known mythical figure often talked about throughout the Middle Ages. ${ }^{32}$ The narrator obviously felt obliged to round off his romance with the universal triumph of Christianity, but the global perspective appears to be the strongest feature here: "We call that land India here; there it is called Tribaliboz" (345). For Anfortas, it is a joy to learn that Secundille, a potential competition for Repanse, had passed away, meaning that "his sister was undisputed lady over many such broad lands" (345). There is a deep sense emerging here that there are no more limits to the Arthurian or the Grail world because fundamental values, ideals, interests, and concepts are shared even with people in very distant lands. In order to heighten the audience's awareness about the huge dimensions of Feirefiz's empire, we are told early on that in his army, he had twenty-five companies from different countries, "none of which understood the others' speech" (308), and: "In his army, assembled from

31. Sylvia Stevens, Family in Wolfram von Eschenbach's Willehalm, mîner mâge triwe ist mir wol kuont. Studies on Themes and Motifs in Literature, 18 (New York: Peter Lang, 1997).

32. Wilhelm Baum, Die Verwandlungen des Mythos vom Reich des Priesterkönigs Johannes: Rom, Byzanz und die Christen des Orients im Mittelalter. Tangenten (Klagenfurt: Verlag Kitab, 1999); Keagan Brewer, Prester John: The Legend and Its Sources (Farnham, Surrey: Ashgate, 2015). 
far afield, was many a wondrous armament" (308). Of course, we are not given any specifics, and this outline is almost in the vein of pre-Orientalism, and yet, there is no doubt at all that Feirefiz, being Parzival's half-brother, represents a high level of courtly culture, this one, however, located in very remote countries. This finds its most dramatic expression in the heathen's decision immediately to finish the fight when Parzival's sword has broken: "The heathen was magnanimous. He spoke courteously then" (311).

Both men communicate in French with each other, which indicates, of course, how the differences among the many people across the world can be overcome at least in linguistic terms. In the case of Rudolf von Ems's Der Guote Gerhard (see above), the protagonist communicates with the Moroccan castellan in Italian, and in the eastern Mediterranean, where European Christians and Arabs meet each other, they draw from the same language to build bridges among each other. ${ }^{33}$ Feirefiz and Parzival then exchange news about each other, and they realize that they are not only the long-lost half-brothers, but they also enjoy the same supreme fame and share the same chivalric values. Feirefiz himself reveals that he is "so mighty . . . that many a land serves my hand with tribute" (312). Parzival has obviously heard about him before, and hence also about his great esteem that he enjoys: "who has won by knightly strength such love and fame that he may lay rightful claims to both" (312). And Feirefiz pronounces, almost in a parallel to the fundamental Christian teaching about the Holy Trinity, "both my father, and you also, and I - we were all one entirely, although it was made manifest in three parts" (314). ${ }^{34}$

In short, Wolfram signals that it was indeed possible for a Christian knight to have family in the vast distances of the Middle East, and especially an individual who is his equal in courtesy, honor, fighting skills, power, and rank as a mighty ruler. Feirefiz fully acknowledges his half-brother and pays great respect to him, and at the same time he honors his own gods, Jupiter and Juno, which is not criticized by Parzival or the narrator. Those gods had helped him to reach with his armada of ships the coast of this land where he could encounter his long-lost family member. Both men then share what they know about their father, Gahmuret, and both lament the unjust death of their father, a tragedy both would like to avenge.

As imaginary as Wolfram's projection here proves to be, we are granted a remarkable insight into his thinking about the deep family connections between the western and the eastern world. Insofar as both half-brothers are granted the opportunity to re-unify, the traditional limits between both parts of the world are lifted and the representatives of both discover their personal bonds and their

33. Multilingualism in the Middle Ages and Early Modern Age: Communication and Miscommunication in the Premodern World, ed. Albrecht Classen. Fundamentals of Medieval and Early Modern Culture, 17 (Berlin and Boston: Walter de Gruyter, 2016).

34. Bumke, Wolfram von Eschenbach (see note 24), 116. 
shared cultural values. ${ }^{35}$ The situation in Wolframs Willehalm carries a number of similarities, but those have already been discussed by numerous other scholars, and they are more complex than the case in Parzival.

\section{Konrad Fleck's Flore und Blanscheflur}

Instead, let us turn to the pan-European romance Flore und Blanscheflur, the title spelt in many different ways depending on the language used. For our purpose, I mostly draw from the German version by Konrad Fleck, composed around 1220, which is considerably more detailed than its French source, for instance, but the differences to other versions are minimal and do not impact our interest to comprehend to what extent this text mirrors early forms of globalism. Again, here we must ignore major sections of the narrative and focus, instead, on the young man's efforts at the end to recover his beloved, the slave girl Blanscheflur, as the one with whom he wants to live, otherwise he would die. ${ }^{36}$

His parents had been very unhappy about this strong emotional relationship between their son and this Christian slave girl, so when they send Flore away for some time to gain more education, they secretly sell Blanscheflur into slavery. They had considered murdering her, but this sale seems to be more efficient and would not leave blood on their hands, as Flore's mother explains to her husband (1510-20). Merchants have arrived from Babylon, and they would be interested in the girl, which proves to be true. And those then manage to sell her later to the Admiral, all of them regarding the poor Blanscheflur as nothing but chattel, a not so uncommon victim of the global

35. Isabelle Vodoz, "Petit récit du temps où l'Allemagne-l'Europe accueillait avec émerveillement le frère noir de Parzival," in Identité(s) multiple(s), ed. Kerstin Hausbei and Alain Lattard (Paris: Presses de la Sorbonne Nouvelle, 2008), 231-37; Elke Brüggen, "Belacâne, Feirefîz und die anderen: Zur Narrativierung von Kulturkontakten im Parzival Wolframs von Eschenbach," in Figuren des Globalen: Weltbezug und Welterzeugung in Literatur, Kunst und Medien, ed. Christiane Moser and Linda Simonis. Global Poetics: Literatur- und Kulturwissenschaftliche Studien zur Globalisierung, 1 (Göttingen: Vandenhoeck \& Ruprecht, 2014), 673-92.

36. Christine Putzo, Konrad Fleck: <Flore und Blanscheflur>. Text und Untersuchungen. Münchener Texte und Untersuchngen zur deutschen Literatur des Mittelalters, 143 (Berlin and Boston: Walter de Gruyter, 2015). The edition reproduces the text in manuscript B in the left column, Berlin, SBPK, Ms. germ. fol. 18 (ca. 1466/68), and manuscript $\mathrm{H}$ in the right column, Heidelberg, Universitätsbibliothek, Cod. Pal. germ. 362 (ca. 1442/44). For a good English translation, though that one of the Old French version from ca. 1155, see The Romance of Floire and Blanchefleur: A French Idyllic Poem of the Twelfth Century, trans. into English verse by Merton Jerome Hubert. University of North Carolina Studies in the Romance Languages and Literatures, 63 (Chapel Hill, NC: The University of North Carolina Press, 1966). 
slave trade which flourished also in the high and late Middle Ages. ${ }^{37}$

To the Admiral's credit, the narrator emphasizes that he immediately recognized the girl's noble origin who would be a worthy partner in marriage for him (1682-86). In fact, he goes so far as to treat her royally, assigning twenty female maids to her and offering her his empathy when he realizes that she is pining away for a lover somewhere in the distance. She would never have a chance to return to him, and she would end her life with the Admiral as his wife. But he does not force her into this marriage immediately; instead, he grants her a year's time to accept her new situation and to get used to the idea of marrying this mighty ruler who would, actually, make her to his queen and thus to the female ruler over the vast empire (1725-27).

Remarkably, Blanscheflur never abandons her love for Flore, and she also dismisses the religious differences between them, with her being a Christian, him being a Muslim (1784-85). For her, in fact, Flore's heathen religion has no relevance for her; she only wants to be with him (1808). In the meantime, many events evolve back home, with Flore at first being told about Blancheflur's alleged death, him then trying to commit suicide out of grief, until his parents reveal the truth to him. This then sets him on a long and adventurous course to Babylon under the pretense of being a merchant, facing many hurdles and challenges, but at the end he succeeds and can make his way to the distant land, finds his beloved in the tower, and manages to get up to her, where the lovers, having become careless following their exceeding joy about being together again, are eventually discovered by the Admiral. The latter, of course, is immediately bent on executing both out of enormous wrath, but then things change radically. Insofar as the two young people demonstrate extraordinary dedication and love for each other, both being ready to die for each other or to preserve the other's life by means of a magical ring which Flore's mother had given to him before his departure (6713-29), the unintentionally exert a deep impact on the entire court society there.

The couple is then led to the open courtyard for their execution, but although they are surrounded by strangers, their noble demeanor and clear demonstration of love for each other move the entire crowd (6805-06), except for the Admiral, who can only think of getting them both burned at the stake because he feels deeply hurt and insulted: "dô was der amiral versteinet" (6978; the Admiral had a heart of stone). They even struggle against each other over who should be the one to be decapitated first by the wrathful ruler. However, when the latter witnesses how both try to save the other and beg him to take his/her life instead of the other, and this out of their love for the other person, and when he hears the laments of his own people begging him

37. Hannah Barker, The Most Precious Merchandise: The Mediterranean Trade in Black Sea Slaves, 1260-1500. The Middle Ages (Philadelphia, PA: University of Pennsylvania Press, 2019). She does not, of course, consider literary sources as a backdrop to her study. 
to spare their lives, his heart begins to melt, and he finally changes his mind and feels deep sympathy and respect for them (7225-35).

Everyone agrees that this show of love would never find a parallel again, and this then concludes the execution scene without anyone having died. Flore then relates all of his adventures to an enraptured audience (7409-441) that eventually breaks out in laughter filled with delight about this good outcome. ${ }^{38}$ Love in its youthful manifestation emerges thus as a unifying force across the world, insofar as it convinces both Flore's father, the Spanish king, and the Babylonian Admiral to acknowledge and respect the love between those two fifteenth-year old youths. Flore's account makes the Admiral both smile and ashamed of his own behavior (7450-53). He is deeply moved and grants their wish to get married, although before he had always demonstrated a most wrathful behavior and had been feared by everyone (7478-499).

Very similar to Wolfram's Parzival, Fleck's romance operates on the assumption that love can overcome all conflicts (amor vincit omnia), and that it has the power to transform even a brutal tyrant such as the Admiral into a member of courtly society sharing the same values and respecting the ideals of love as demonstrated by Flore and Blanscheflur. Moreover, in order to facilitate the marriage, he confers knighthood upon Flore (7504), thus operating like any worthy king in the West.

What Fleck, and with him many other European poets projected here, constitutes a literary effort to imagine that the ideals of love carry across the world and that even the cruelest ruler in Persia or somewhere nearby would yield to its force. Insofar as the Admiral then takes Blancheflur's maid Claris as his own wife, great festivities set in that prove to be entirely in uniformity with those celebrated in common courtly settings anywhere in the world, especially because everyone participates in the joyful events: "daz nieman niht wan vröide pflac" (7564; everyone was filled with great joy). ${ }^{39}$

The narrator makes every effort to portray the social setting there in Babylon as completely identical with those anyone would expect at a traditional court (King Arthur). All foreignness falls away, and the values of courtly love

38. In medieval literature, we hear often about laughter, happy and joyful, and it commonly characterizes the fundamental value system of courtly society. This is the case here as well, which casts the world of Babylon, despite the tyrannical rule by the Admiral, suddenly as equal to that of the Spanish king and of Christian rulers elsewhere. See the contributions to Laughter in the Middle Ages and Early Modern Times: Epistemology of a Fundamental Human Behavior, Its Meaning, and Consequences, ed. Albrecht Classen. Fundamentals of Medieval and Early Modern Culture, 5 (Berlin and New York: Walter de Gruyter, 2010).

39. Siegfried Christoph, "The Language and Culture of Joy," Words of Love and Love of Words in the Middle Ages and the Renaissance, ed. Albrecht Classen. Medieval and Renaissance Texts and Studies, 347 (Tempe, AZ: Arizona Center for Medieval and Renaissance Studies, 2008), 319-33. 
and then also marriage find full realization. When Flore then learns that his father has died and that Spain needs him to return home to take over the orphaned throne, both the Admiral and the entire court at first beg him to stay, demonstrating now the intense friendship and emotional companionship among them all, but eventually the new couple departs out of necessity, leaving behind a sorrowful court (7725), deeply grieved, crying, and lamenting their journey home. This is, after all, truly a sentimental romance: "hundert tûsent ougen wurden naz, / dô sie scheiden wolten dannen" (7762-63; hundred thousand eyes shed tears when they wanted to depart), but the outcome also demonstrates that for European audience the fierce and hostile world in the East could easily be transformed and then participate in the global practice of courtliness. We do not hear anything else about the Admiral and his marriage with Claris, and there are no words about their religion, whereas Floris converts to Christianity upon his return home, and requests from his people to do the same (7825-30).

If Blancheflur would not have been sold into slavery by Flore's parents, the entire drama would not have set in the way it does. And it might have been highly questionable whether these two young people would have been allowed to marry back home if this had not happened. They succeed in finding to each other only in the distant world of western Asia, and there their profound love has also a transformative influence on the Admiral and his people. Fleck, like many of his contemporaries and late medieval successors, deliberately utilized the notion of the distant world in order to create a setting where the drama for the two lovers reaches its peak. They almost would have been executed, but their public display of their emotions safeguards them, and also creates a new bond of friendship with the Admiral and his people.

\section{Reinfried von Braunschweig}

Our third example, the anonymous Reinfried von Braunschweig (ca. 1280), is similarly determined by strong sentimentality, but we are given the most insights into the conditions of the Oriental world in comparison with the two previous examples. The poet drew heavily from previous romances and epic poems, especially from Wolfram von Eschenbach's Parzival and Willehalm, and then also from Konrad von Würzburg's Engelhard, and combined in many different ways the two genres of the courtly romance with the crusade epic..$^{40}$ All we can say for

40. Albrecht Classen, "The Crusader as Lover and Tourist: Utopian Elements in Late Medieval German Literature: From Herzog Ernst to Reinfried von Braunschweig and Fortunatus," in Current Topics in Medieval German Literature: Texts and Analyses (Kalamazoo Papers 2000-2006), ed. Sibylle Jefferis. Göppinger Arbeiten zur Germanistik, 748 (Göppingen: Kümmerle, 2008), 83-102. 
sure is that this huge narrative was composed after 1291 because in verse 17980 we hear that the heathens (Mameluks) had conquered again the Christian fortress of Acre. The linguistic features indicate that the poet originated from Switzerland, but he likely served at the court of Duke Henry the Lion in Brunswick. This anonymous opus falls into the same category as the anonymous Friedrich von Schwaben and Johann von Würzburg's Wilhelm von Österreich, all dealing with the various issues of courtly love, marriage, adventures, heroism, and crusades, aiming at broader entertainment and yet also reflecting deeper concerns with ethical and social aspects as represented by the protagonist. ${ }^{41}$

To what extent might the crusading theme in the second part of this epic poem mirror traces of globalism? Hostile crusader mentality would certainly not belong to that category, and the crusade actually plays a major role here for two thirds of the romance. However, after much back and forth on the battlefield pitting Christians against Muslims, finally the protagonist encounters the supreme fighter on the other side, the Persian prince. While we do not learn much about his personal circumstances, the poet takes great pain to introduce him as a most outstanding character who enjoys great respect among his contemporaries in the Middle East and who quickly proves to be, at least within this narrative framework, a highly worthy, noble, and dignified individual, irrespective of his non-Christian religion. ${ }^{42}$ In some ways, he appears to be modeled after the example of the shining warrior Arofels in Wolfram von Eschenbach's Willehalm, Gyburg's uncle, whom the narrator also mentions by name, and who appears to be a perfect match for the protagonist in courtly and knightly terms, but he represents the Muslim world and thus becomes a victim of Willehalm's bitter fighting fury following the complete defeat of his army.43 The situation in Reinfried takes a most interesting turn and opens a significant window toward globalism already at the end of the thirteenth century.

41. Johannes Janota, Vom späten Mittelalter zum Beginn der Neuzeit. Part I: Orientierung durch volkssprachige Schriftlichkeit (1280/9-1380/90). Geschichte der deutschen Literatur von den Anfängen bis zum Beginn der Neuzeit, III (Tübingen: Max Niemeyer, 2004), 198-202; see also Wolfgang Achnitz, Babylon und Jerusalem: Sinnkonstituierung im "Reinfried von Braunschweig" und $m$ "Apollonius von Tyrland" Heinrichs von Neustadt. Hermaea. Germanistische Forschungen, Neue Folge, 98). See also Herfried Vögel, Naturkundliches im 'Reinfried von Braunschweig'. Mikrokosmos. Beiträge zur Literaturwissenschaft und Bedeutungsforschung, 24 (Frankfurt a. M., Bern, et al.: Peter Lang, 1990).

42. Reinfried von Braunschweig. Mittelhochdeutscher Text nach Karl Bartsch. Übersetzt und mit einem Stellenkommentar versehen von Elisabeth Martschini. 3 vols (Kiel: Solivagus-Verlag, 2017-2019); cf. my review forthcoming in Mediaevistik 33.

43. Wolfram von Eschenbach, Willehalm. Trans. by Marion E. Gibbs and Sidney M. Johnson (Harmondsworth, Middlesex: Penguin, 1984), Book II, pp. 61-53; see, for instance, James A. Rushing, Jr., "Arofel's Death and the Question of Willehalm's Guilt," in Journal of English and Germanic Philology 94.4 (1995), 469-82; Florian Nieser, "Das getilgte Ding: Arofels Schild im 'Willehalm' Wolframs von Eschenbach," in Beiträge zur Geschichte der deutschen Sprache und Literatur 139.3 (2017), 329-44. 
He is said to be brave and bold (16751), generous in words and deeds (16752), and highly esteemed far and wide, a true leader of his people (16814). The narrator uses a whole stream of superlatives to characterize him as the besteducated person, as highly virtuous, loyal, and also physically strong. Moreover, he has already demonstrated to be a fair ruler (16830), treating both the poor and the rich fairly and justly (16832-33). His service for ladies proves to be impeccable, and so his constant striving for virtues (16850-51). According to the narrator, he shines in his intellectual abilities and the purity of his heart, and this in strong contrast to the moral and ethical failures of the people living in the Christian world (16897-933).

This Persian prince, the flower of his country and people, the shining star of the entire heathen army, is then selected to fight against Reinfried, and the outcome of their combat would then decide the result of the entire war campaign, the Crusade. The stakes are hence extremely high, but both sides accept them happily and enjoy the spectacle of these two outstanding warriors facing each other off. Curiously, this duel is then not identified as a struggle over which religion is the right one, but a fight on behalf of courtly love and courtly ladies (17013-14), although for Reinfried the religious purpose remains of central importance (16999). The narrator includes subtle but certain clues into the description of both men's armor that indicate already here that Reinfried will gain the victory. While the Persian prince exclusively emphasizes love in the design of his armor, the protagonist dedicates himself to the Virgin Mary (17175-77) and identifies himself with his own dynasty, Braunschweig. Nevertheless, the mortal joust demonstrates quickly that they both are of equal strength and power (17366-67) and have truly found a match in the other (17494-99).

Nevertheless, Reinfried overcomes the Persian, but his friends and family members plead for his life and eventually agree to cede the Holy Land to the Christians. The ruler of Babylon promises, "swaz ich hab ald ie gewan / ald iemer mê gewinnen kan / mac daz sîn sterben wenden" (17619-21; everything that I own, or have won, and will gain in the future will be yours if it can help to prevent his death). The narrator emphasizes that most other people would have accepted a monetary award instead of demanding such a prize for Christianity, and thus underscores Reinfried's virtues and religiosity, whereas most of his contemporaries would be characterized by their personal greed (17687). This crusader, by contrast, had not undertaken his arduous military campaign for personal profit, and thus deserves, as we are told repeatedly, to be praised as an exceptional role model for his society.

What really matters for us, however, is the question regarding the way of how the relationship between the Persian and Reinfried develops. At first, after the fight has ended, both embrace each other and demonstrate their mutual respect (17820-21), then the former invites the latter to accompany him on a touristic visit of his empire, and this in order to honor all courtly ladies (17823-27). Most important, however, the Persian pleads with him not to force 
him to accept the Christian faith because it would dishonor him among his own people, while the formal conversion would not change his mind at any rate. Indeed, Reinfried realizes that no one can be forced to convert sincerely, so he quickly abandons this plan and acknowledges his new 'friend' as what he is, a heathen, without pushing him any further in this religious matter: "ob ich in einen kristen tuo / und er doch wil ein heiden sîn, / der missetæte schuld ist mîn" (17892-94; when I force him to become a Christian, although he wants to be a heathen, then the guilt will be mine). Christianity would not even profit from this fake conversion (17902-05), so Reinfried abstains from any further efforts, takes over the Holy Land, repairs all the holy sites, and then accepts, above all, the Persian as an equal whose invitation to tour his vast empire he then accepts happily.

This section proves to be heavily influenced by much traditional monster lore and accounts about the wonders of the so-called exotic East, such as the anonymous Herzog Ernst (ms. B, ca. 1220) or, in greater distance, the Old English Wonders of the East (ca. 1000). ${ }^{44}$ Much of medieval imagination and fantasy were occupied with those miraculous phenomena located somewhere in the Orient, sometimes viewed with considerable skepticism, but mostly embraced with awe and intrigue. ${ }^{45}$ Nevertheless, the narrator also quotes some people who have voiced considerable criticism and doubt about the various monsters (19667ff.), which he then rejects himself (19683ff.), but what matters for us here is that the Persian and Reinfried experience those wonders together and tour a fantasy world of extraordinary proportions and features. When they face military challenges, they fight together (19980-85), sharing everything in their lives. In these two people, East and West have come together and cooperate as equal partners. Many times, the conflicts are no longer those between the heathen and the Christian, but between these two heroes on the one hand and monstrous beings on the other. All previous criteria characteristic of the Eurocentric worldview here have been replaced by the struggle against hostile non-human or half-human forces.

What matters in the last section of Reinfried von Braunschweig concerns only the marvelous and the protagonist's knightly accomplishments, whereas cultural and religious differences are no longer of relevance. The Persian and his friend experience the wonders of the East together, fight together, travel together, and enjoy the marvels as they encounter them in a seemingly endless stream of occurrences. Whereas in Herzog Ernst (explicit reference: 20056-66) the protagonist never abandons his sense of superiority over the various monster peoples,

44. See, for instance, A. J. Ford, Marvel and Artefact: The 'Wonders of the East' in Its Manuscript Context. Library of the Written Word, 45 (Leiden and Boston: Brill, 2015).

45. Albrecht Classen, "Imagination, Fantasy, Otherness, and Monstrosity in the Middle Ages and the Early Modern World. New Approaches to Cultural-Historical and Anthropological Epistemology: Also an 'Introduction'," in Imagination and Fantasy (see note 15). 
although he serves the king of one of them in his fight against external threats, in Reinfried, there is no longer any barrier between the two men, which altogether represents a literary projection of 'transculturality' in the literal sense of the word.

They are equally frightened by a strange sculpture, and equally laugh about it once they have realized its true nature (21238-45). They marvel together about odd phenomena (212556-59), and they investigate them as a team (21276-77), such as by way of reading together a mysterious inscription on an epitaph (21300-05). They also help each out as well to protect themselves against the danger of the siren: "er hiez mit lîsteclîcher art/den Persân sînen lieben/knehten schôn verschieben/diu ôren umb und umbe" (22346-49; he also instructed them in a clever manner to close up entirele the ears of the Persian, his good friend [servant]). After the adventure with the siren, Reinfried suffers badly and longs dearly for her, but his friend the Persian consoles him and strongly urges him to remember his manly virtues and his true love for his wife Yrkâne back home: "phî, tuont hin den bœsen muot,/ob iuch ie liebe wart bekant" (22700-01; eew, dismiss this foul sense if you have ever experienced true love). In fact, Reinfried had actually forgotten her, and only because the Persian alerts him to this danger of losing his true mindset, does the protagonist return to his original self and ideals.

One more example for this astounding partnership, unheard of otherwise in medieval and early modern literature, may suffice to understand how much the anonymous poet developed a new sense of personal relationships that serves to invite the audience to open their minds toward foreign lands and people and embrace them as worthy equals and perhaps also as friends. Both heroes encounter a boy who laments the alleged death of Reinfried and the Persian, and characterizes them as "hergesellen" (22886; companions in war) who enjoy the highest respect across the world (22888-91). As soon as both have then reached the court of King Aschalon, they are welcomed with greatest joy: "ich wæne sô friuntlîche/man ie geste enphienge" (2304-41; I believe that never before guests were welcomed in such a cheerful manner).

The relationship between both men never changes again, and the narrator also continues to call him "der werde Persân" (27106; the worthy Persian). Since the text has survived only as a fragment, we do not need to pursue the narrative further, especially because one marvelous adventure replaces another, while the two protagonists cooperate and assist each other without fail to come to terms with it. To what extent could we thus identify them as early members of a global community? Does globalism hence find sustainable support in this verse narrative, and this in comparison with the previous two texts? 


\section{Conclusion}

Many medieval travelers - merchants, diplomats, pilgrims, artists, scholars, masons, architects, rulers, friars, etc. - roamed the roads crisscrossing Europe, and many found their way even into the distant East. Traveling and merchandising, for instance, established bridges, but they do not create necessarily globalism. If we understand with this term the notion that two or more different worlds come together in a kind of harmonious, mutually respectful manner, we find powerful illustrations in literary examples, such as Parzival, Flore und Blanscheflur, and Reinfried von Braunschweig, where the individual breaks through the barriers to foreign worlds and experiences, often in a rather surprising manner, that she/he can establish friendship or find love.

As different as these three examples prove to be in terms of their generic features, they all indicate that Europeans could or even should reach out to their contemporaries who then would respond in kind and welcome them in a peaceful and respectful manner. Undoubtedly, wherever we look, we always realize that Christianity was supposed to dominate, which we would not recognize today as true globalism. Instead, this overarching attempt to spread the Christian religion, as described also in these three literary texts, constitutes a form of imperialism. However, below the surface, at least in all our examples, we recognize significant attempts to reach out to other cultures, to embrace the foreigners as fellow human-beings endowed with great virtues and values. Friendship and love are thus possible across all cultural and religious divides, as the three authors indicate. The issue here does not necessarily address toleration and tolerance ${ }^{46}$ but it is closely related and could lead over to this intellectual mind-set of openness and mutual acceptance.

Globalism also entails that an individual, for instance, leaves his home country and voluntarily pursues efforts to get to know foreign countries and people, and this in a respectful manner. Despite the crusading motif in Reinfried von Braunschweig, here we recognize the greatest effort to take the protagonist far outside of the familiar framework and situate him, in close companionship with the Persian prince, in the world of wonders which both explore with great curiosity. In Flore und Blanscheflur, the male protagonist pursues his beloved, enslaved to the Babylonian Admiral, and succeeds not only to gain her freedom and thus to marry her, but he also transforms the Admiral's heart and reminds him of the global value of courtliness and virtues. In Parzival, the protagonist's father Gahmuret operates most successfully in the Middle East until he is tragically killed when his diamond helmet is made soft as butter by means of he-

46. Albrecht Classen, Toleration and Tolerance in Medieval and Early Modern European Literature. Routledge Studies in Medieval Literature and Culture, 8 (New York and London: Routledge, 2018). I have addressed all three texts under discussion here and many more, but not in terms of globalism. 
goat blood. The reactions of the ruler and his people demonstrate their great grief, and they then make every effort to honor the deceased. At the end, the two halfbrothers meet, and they indirectly join hands to save the Grail kingdom (Parzival) and then to bring Christianity to India (Feirefiz).

The stage of operation is changing in all three texts, which brings the protagonists into close contact with representatives from the East. While some scholars have radically dismissed all those new literary strategies as deceptive, if not even hypocritical, that is, as a thin veil covering deeply-rooted imperialism and Eurocentrism, ${ }^{47}$ we need to be more sensitive and accept the actual changes in the orientation presented here. Since the thirteenth century, we might say, the world opened up for Europeans, and even if they continued to see the new countries and peoples through a narrow lens, they endeavored quite successfully to present an increasingly global perspective, at least in fictional terms. Virtues, ideals, and emotions were recognized as universally shared, which constitutes, until today, a basis for globalism.

\section{Bibliography}

Achnitz, Wolfgang. Babylon und Jerusalem: Sinnkonstituierung im "Reinfried von Braunschweig" und im "Apollonius von Tyrland" Heinrichs von Neustadt. Hermaea. Germanistische Forschungen, Neue Folge, 98. Tübingen: Max Niemeyer, 2002.

Barker, Hannah. The Most Precious Merchandise: The Mediterranean Trade in Black Sea Slaves, 1260-1500. The Middle Ages. Philadelphia, PA: University of Pennsylvania Press, 2019.

Baum, Wilhelm. Die Verwandlungen des Mythos vom Reich des Priesterkönigs Johannes: Rom, Byzanz und die Christen des Orients im Mittelalter. Tangenten. Klagenfurt: Verlag Kitab, 1999.

Beaujard, Philippe. From the Seventh Century to the Fifteenth Century CE. The Worlds of the Indian Ocean, 2, translated and edited by Tamara Loring, Frances Meadows, and Andromeda Tait. Cambridge: Cambridge University Press, 2019 (orig. 2012).

Block Friedman, John and Kristen Mossler Figg (ed.). Trade, Travel, and Exploration in the Middle Ages: An Encyclopedia. New York and London: Garland, 2000.

Borgolte, Michael. "Kommunikation-Handel, Kunst und Wissenstausch." Weltdeutungen und Weltreligionen 600 bis 1500, edited by Johannes Fried and

47. Jerold C. Frakes, Vernacular and Latin Literary Discourses of the Muslim Other in Medieval Germany. The New Middle Ages (New York: Palgrave Macmillan, 2011); see my review in Mediaevistik 25 (2012/2013), 194-96; or Katja Altpeter-Jones's, in Seminar 49.1 (2013), 91-93. 
Ernst-Dieter Hehl. WBG Welt-Geschichte, III. Darmstadt: Wissenschaftliche Buchgesellschaft, 2010, pp. 17-144.

Bray, R. S. Armies of Pestilence: The Effects of Pandemics on History. Cambridge: Lutterworth Press, 1996.

Brüggen, Elke. "Belacâne, Feirefîz und die anderen: Zur Narrativierung von Kulturkontakten im Parzival Wolframs von Eschenbach." In Figuren des Globalen: Weltbezug und Welterzeugung in Literatur, Kunst und Medien, ed. Christiane Moser and Linda Simonis. Global Poetics: Literatur- und Kulturwissenschaftliche Studien zur Globalisierung, 1. Göttingen: Vandenhoeck \& Ruprecht, 2014, pp. 673-92.

Cascio, Elio Lo. (ed.). L' impatto della "peste antonina": quinto degli Incontri capresi di Storia dell'Economia Antica. Bari: Edipuglia, 2012.

Classen, Albrecht. (ed.). East Meets West in the Middle Ages and Early Modern Times: Transcultural Experiences in the Premodern World. Fundamentals of Medieval and Early Modern Culture, 14 Berlin and Boston: Walter de Gruyter, 2013.

Classen, Albrecht (ed.). Travel, Time, and Space in the Middle Ages and Early Modern Time: Explorations of Worldly Perceptions and Processes of Identity Formation. Fundamentals of Medieval and Early Modern Culture, 22. Berlin and Boston: Walter de Gruyter, 2018.

Classen, Albrecht. "India, Persia, and Arabia in the Mind of a Late FifteenthCentury German Author: Transcultural Experiences through the Literary Discourse. Antonius von Pforr and his Buch der Beispiele der Alten Weisen." Philological Quarterly 99, no. 2 (2020): 119-45.

Classen, Albrecht. (ed.). Meeting the Foreign in the Middle Ages. New York and London: Routledge, 2002.

Classen, Albrecht. Religious Toleration in the Middle Ages and Early Modern Age: An Anthology of Literary, Theological, and Philosophical Texts. Berlin: Peter Lang, 2020.

Classen, Albrecht (ed.). Imagination and Fantasy in the Middle Ages and Early Modern Time: Projections, Dreams, Monsters, and Illusions. Fundamentals of Medieval and Early Modern Culture, 24. Berlin and Boston: Walter de Gruyter. [forthcoming [2020].

Classen, Albrecht. Tolerance in the Middle Ages? The Good Heathens as Fellow Beings in the World of Reinfried von Braunschweig, Konrad von Würzburg's Partonopier und Meliur, and Die Heideninne." In Amsterdamer Beiträge zur älteren Germanistik 61 (2006): 183-223.

Classen, Albrecht. An English Translation of Rudolf von Ems's Der guote Gêrhart. Newcastle upon Tyne: Cambridge Scholars Press, 2016.

Classen, Albrecht. "The Transnational and the Transcultural in Medieval German Literature: Spatial Identity and Pre-Modern Concepts of Nationhood in the Works of Wolfram von Eschenbach, Gottfried von Straßburg, Rudolf von Ems, and Konrad von Würzburg." In Mediaevistik 29 (2016): 175-94. 
Classen, Albrecht. "Medieval Transculturality in the Mediterranean from a Literary-Historical Perspective: The Case of Rudolf von Ems's Der guote Gêrhart (ca. 1220-ca. 1250)." In Journal of Transcultural Medieval Studies 5, no.1 (2018): 133-60.

Classen, Albrecht. (ed.). Multilingualism in the Middle Ages and Early Modern Age: Communication and Miscommunication in the Premodern World. Fundamentals of Medieval and Early Modern Culture, 17. Berlin and Boston: Walter de Gruyter, 2016.

Classen, Albrecht. (ed.). Laughter in the Middle Ages and Early Modern Times: Epistemology of a Fundamental Human Behavior, Its Meaning, and Consequences. Fundamentals of Medieval and Early Modern Culture, 5. Berlin and New York: Walter de Gruyter, 2010.

Classen, Albrecht. "Imagination, Fantasy, Otherness, and Monstrosity in the Middle Ages and the Early Modern World. New Approaches to CulturalHistorical and Anthropological Epistemology: Also an 'Introduction'." In Classen (ed.). Imagination and Fantasy in the Middle Ages and Early Modern Time 2020 (forthcoming).

Classen, Albrecht. Toleration and Tolerance in Medieval and Early Modern European Literature. Routledge Studies in Medieval Literature and Culture, 8. New York and London: Routledge, 2018.

Classen, Albrecht. "The Crusader as Lover and Tourist: Utopian Elements in Late Medieval German Literature: From Herzog Ernst to Reinfried von Braunschweig and Fortunatus." In Current Topics in Medieval German Literature: Texts and Analyses (Kalamazoo Papers 2000-2006), edited by Sibylle Jefferis. Göppinger Arbeiten zur Germanistik, 748. Göppingen: Kümmerle, 2008, pp. 83-102.

Conrad, Sebastian. What is Global History? Princeton, NJ: Princeton University Press, 2016.

Darge, Rolf. "Wahre Welt: Die Welt als offenes Beziehungsfeld des menschlichen Geistes im mittelalterlichen Denken." In Welterfahrung und Welterschließung in Mittelalter und Früher Neuzeit, ed. Anna Kathrin Bleuler. Interdisziplinäre Beiträge zu Mittelalter und Früher Neuzeit, 5. Heidelberg: Universitätsverlag Winter, 2016, pp. 25-45.

de Courcelles, Dominique (ed.) La Raison du merveilleux à la fin du Moyen Âge et dans la première modernité: Textes et images. Rencontres, 399. Paris: Classiques Garnier, 2019.

Demacopoulos, George E. Colonizing Christianity: Greek and Latin Religious Identity in the Era of the Fourth Crusade. New York: Fordham University Press, 2019.

Dinzelbacher, Peter (ed.). Europäische Mentalitätsgeschichte: Hauptthemen in Einzeldarstellungen, $2^{\text {nd }}$ revised and expanded ed. Stuttgart: Alfred Kröner Verlag, 2008 (orig. 1993).

Doctors without borders. https://www.doctorswithoutborders.org/. Last accessed March 26, 2020. 
Ford, A. J. Marvel and Artefact: The 'Wonders of the East' in Its Manuscript Context. Library of the Written Word, 45. Leiden and Boston: Brill, 2015.

Frakes, Jerold C. Vernacular and Latin Literary Discourses of the Muslim Other in Medieval Germany. The New Middle Ages. New York: Palgrave Macmillan, 2011.

Green, Monica. (ed.). Pandemic Disease in the Medieval World: Rethinking the Black Death. Leeds: Arc Humanities Press, 2015.

Giraldez, Arturo. The Age of Trade: The Manila Galleons and the Dawn of the Global Economy. Exploring World History. Lanham, MD, Boulder, CO, et al. Rowman \& Littlefield, 2015.

Harper, Kyle. The Fate of Rome: Climate, Disease, and the End of an Empire. The Princeton History of the Ancient World. Princeton, NJ, and Oxford: Princeton University Press, 2017.

Hartmann, Heiko. Einführung in das Werk Wolframs von Eschenbach. Einführung Germanistik. Darmstadt: Wissenschaftliche Buchgesellschaft, 2015.

Hardt, Mark D. History of Infectious Disease Pandemics in Urban Societies. Lanham, MD, Boulder, CO, New York, and London: Lexington Books, 2016.

Hays, J. N. The Burdens of Disease: Epidemics and Human Response in Western History. New Brunswick, NJ: Rutgers University Press, 2009.

Heng, Geraldine and Lynne Ramey. "Early Globalities, Global Literatures: Introducing a Special Issue on the Global Middle Ages." Literature Compass (2014): 1-6. 10.1111/lic3.12156 (last accessed on March 26, 2020).

Heng, Geraldine. "Reinventing Race, Colonization, and Globalisms across Deep Time: Lessons from the Longue Durée." In PMLA 130, no. 2 (2015): 358-66.

Heng, Geraldine. "Early Globalities, and Its Questions, Objectives, and Methods: An Inquiry into the State of Theory and Critique." In Exemplaria 26, no. 2-3 (2014): 232-51.

Janota, Johannes. Vom späten Mittelalter zum Beginn der Neuzeit. Part I: Orientierung durch volkssprachige Schriftlichkeit (1280/9-1380/90). Geschichte der deutschen Literatur von den Anfängen bis zum Beginn der Neuzeit, III. Tübingen: Max Niemeyer, 2004

Jackson, Mark (ed.). The Routledge History of Disease,. The Routledge Histories. London and New York: Routledge, Taylor \& Francis, 2017.

Jankrift, Kay Peter. Im Angesicht der "Pestilenz": Seuchen in westfälischen und rheinischen Städten (1349-1600). Stuttgart: Franz Steiner Verlag, 2020.

Juergensmeyer, Mark, Sassen, Saskia, and Manfred B. Steger (ed.). The Oxford Handbook of Global Studies. New York: Oxford University Press, 2019.

Keagan Brewer, Prester John: The Legend and Its Sources. Farnham, Surrey: Ashgate, 2015.

Legassie, Shayne Aaron. The Medieval Invention of Travel. Chicago and London: The University of Chicago Press, 2017.

Little, Lester K. (ed.). Plague and the End of Antiquity: The Pandemic of 541-750. Cambridge: Cambridge University Press, 2007. 
Lodén, Sofia (ed.). L'expérience des frontières et les littératures de l'Europe Médiévale, and Vanessa Obry. Colloques congres conference moyen âge, 26. Paris: Éditions Honoré Champion, 2019.

Meyer, Evelyn. "Wolfram von Eschenbach's Parzival: A Complex Reshaping and Expansion of a Source." In Seigneurie, Ken et al. (ed.). A Companion to World Literature, vol. 2, 967-77.

Middell, Matthias (ed.). The Practice of Global History: European Perspectives. London, New York, et al.: Bloomsbury Academic, 2019.

Mielke, Andreas. Nigra sum et formosa: Afrikanerinnen in der deutschen Literatur des Mittelalters; Texte und Kontexte zum Bild des Afrikaners in der literarischen Imagologie. Helfant-Texte, 11. Stuttgart: Helfant Ed., 1992.

Nieser, Florian. “Das getilgte Ding: Arofels Schild im 'Willehalm' Wolframs von Eschenbach." In Beiträge zur Geschichte der deutschen Sprache und Literatur 139, no.3 (2017): 329-44.

Perry, David M. Sacred Plunder: Venice and the Aftermath of the Fourth Crusade. University Park, PA: Pennsylvania State University Press, 2015.

Prager, Debra N. Orienting the Self: The German Literary Encounter with the Eastern Other. Studies in German Literature, Linguistics, and Culture. Rochester, NY: Camden House, 2014.

Putzo, Christine. Konrad Fleck: >Flore und Blanscheflur<. Text und Untersuchungen. Münchener Texte und Untersuchungen zur deutschen Literatur des Mittelalters, 143. Berlin and Boston: Walter de Gruyter, 2015.

Raucheisen, Alfred. Orient und Abendland: ethisch-moralische Aspekte in Wolframs Epen "Parzival" und "Willehalm". Bremer Beiträge zur Literatur- und Ideengeschichte, 17. Frankfurt a. M. and New York: Peter Lang, 1997.

Reinfried von Braunschweig. Mittelhochdeutscher Text nach Karl Bartsch. Übersetzt und mit einem Stellenkommentar versehen von Elisabeth Martschini. 3 vols. Kiel: Solivagus-Verlag, 2017-2019.

Rushing, Jr., James A. “Arofel's Death and the Question of Willehalm's Guilt.” In Journal of English and Germanic Philology, 94 no. 4 (1995): 469-82

Salisbury, Joyce E. (ed.). The Greenwood Encyclopedia of Global Medieval Life and Culture, 3 vols. Westport, CT, and London: Greenwood Press, 2009.

Salisbury, Joyce E. "Europe." In Salisbury, Joyce E. (ed.). The Greenwood Encyclopedia of Global Medieval Life and Culture. Westport, CT, and London: Greenwood Press, 2009, pp. 1-178.

Schirok, Bernd. "Die Handschriften und die Entwicklung des Texts." Wolfram von Eschenbach: Ein Handbuch, edited by Joachim Heinzle. vol. I: Autor, Werk, Wirkung. Berlin and Boston: Walter de Gruyter, 2011, pp. 308-34.

Seigneurie, Ken et al. (ed.). A Companion to World Literature, vol. 2, ed. Christine Chism: 601 CE to 1450. Chichester, West Sussex: John Wiley \& Sons, 2020.

Siegfried, Christoph. "The Language and Culture of Joy." In Classen, Albrecht (ed.). Words of Love and Love of Words in the Middle Ages and the Renaissance, 
Medieval and Renaissance Texts and Studies, 347. Tempe, AZ: Arizona Center for Medieval and Renaissance Studies, 2008, pp. 319-33.

Standen, Naomi and Monica White. "Structural Mobilities in the Global Middle Ages." In Past \& Present 238, suppl. 13 (2018): 158-89.

Stevens, Sylvia. Family in Wolfram von Eschenbach's Willehalm, mîner mâge triwe ist mir wol kuont. Studies on Themes and Motifs in Literature, 18. New York: Peter Lang, 1997.

Tayor, Larissa J., Craig, Leigh Ann, et al. (ed.). Encyclopedia of Medieval Pilgrimage. Leiden and Boston: Brill, 2010.

Tinsley, David F. "Mapping the Muslims: Images of Islam in Middle High German Literature of the Thirteenth Century." In Contextualizing the Muslim Other in Medieval Christian Discourse, edited by Jerold C. Frakes. The New Middle Ages. New York: Palgrave Macmillan, 2011, pp. 65-101.

Vodoz, Isabelle. "Petit récit du temps où l'Allemagne-l'Europe accueillait avec émerveillement le frère noir de Parzival." In Identité(s) multiple(s), edited by Kerstin Hausbei and Alain Lattard. Paris: Presse de la Sorbonne Nouvelle, 2008, 231-37.

Vögel, Herfried. Naturkundliches im 'Reinfried von Braunschweig'. Mikrokosmos. Beiträge zur Literaturwissenschaft und Bedeutungsforschung, 24 Frankfurt a. M., Bern, et al.: Peter Lang, 1990.

Vögele, Jörg, Stefanie Knöll, and Thorsten Noack (ed.). Epidemien und Pandemien in historischer Perspektive. Neuere Medizin- und Wissenschaftsgeschichte. Wiesbaden: Springer VS, 2016.

Wallace, David (ed.). Europe: A Literary History, 1348-1418, 2 vols. Oxford: Oxford University Press, 2016.

Wenzlhuemer, Roland. Doing Global History: An Introduction in Six Concepts. London: Bloomsbury Academic, 2020.

Whatley, Laura J. "Shifting Paradigms of Place and Ritual on Crusader Seals Before and After the Fall of Acre in 1291." In Paradigm Shifts during the Global Middle Ages and the Renaissance, edited by Albrecht Classen. Arizona Studies in the Middle Ages and the Renaissance, 44. Turnhout: Brepols, 2019, 43-63.

Wolfram von Eschenbach. Parzival. Studienausgabe. $2^{\text {nd }}$ ed. Mittelhochdeutscher Text nach der sechsten Ausgabe von Karl Lachmann. Übersetzung von Peter Knecht. Berlin and New York: Walter de Gruyter, 1998.

Wolfram von Eschenbach,. Willehalm. Translated by Marion E. Gibbs and Sidney M. Johnson, Book II. Harmondsworth, Middlesex: Penguin, 1984. 

Athens Journal of Humanities \& Arts - Volume 8, Issue 8, January 2021 - Pages 45-62

\title{
John Dewey on Stages of Morality and Self-Realization Confronting Death
}

\author{
By William O'Meara*
}

\begin{abstract}
Much moral speculation has been devoted to the problem, of equating personal happiness and regard for the general good, note John Dewey and Tufts. If I do what is morally right for justice and benevolence, will I necessarily be happy or rewarded with happiness? In fact, some very bad people are happy, and some very good people suffer terribly. The problem thus put seems insoluble in this life and soluble only in the next life in which the bad will be punished and the good will be rewarded. However, Dewey and Tufts argue: "the problem is insoluble because it is artificial." The argument of Dewey is not that morality is to be viewed as a means to an external end of happiness whether in this life or in a life after death but that morality involves a profound transformation of the self in an ongoing process that aims to transform the self so that one is a fit member of the developing moral community that all moral agents may seek even if one were to die in being true to the moral transformation of the self and of the community. This paper will support Dewey's argument by a consideration of the way Socrates confronts his death as interpreted by Plato especially in The Apology which is agnostic about the immortality of the soul rather than in The Phaedo which affirms the immortality of the soul. For the dying of Socrates for the central moral value of his life, the examined way of life, is not unique as a moral decision. On the contrary, it is a moral decision that exemplifies what should be going on in moral decisions all the time, that is, precisely the subordination of earlier felt desires and impulses and social roles from babyhood and childhood to the highest moral ideals of the examined way of life and the life of mutual respect in the virtues which Dewey does not, of course, grasp as eternal Platonic forms of moral values. Socrates has always subordinated his life of sensation and emotion to the more lasting values of morality, and he is more deeply happy in finding his self-realization in striving to realize something greater than himself, the ongoing, social self involved in the moral community of self-examination and of virtue than in merely continuing to live.
\end{abstract}

\section{Dewey on Moral Development as a Process}

The paper begins by identifying the three broad stages of moral development for John Dewey.

We may distinguish then three levels of conduct.

1. Conduct arising from instincts and fundamental needs. To satisfy these needs certain conduct is necessary, and this in itself involves ways of acting which are more or less rational and social....

"Professor, Department of Philosophy and Religion, James Madison University, USA. 
2. Conduct regulated by standards of society, for some more or less conscious end involving the social welfare. [This is t] he level of custom...

3. Conduct regulated by a standard which is both social and rational, which is examined and criticized. [This is t] he level of conscience. ${ }^{48}$

\section{The Pre-Moral or Pre-Conventional Stage}

Reflecting upon the pre-moral or pre-conventional stage of development, we may say that it is Dewey's view that the human nature of an individual is not found in isolated instincts that could only be focused upon achieving the respective goals of the instincts. Except for the sucking reflex and the fright reaction in the new born infant, the baby's activities are not the direct result of instinctual impulses or the emotional need to suck and do not seek well-defined goals or conscious ends, and even then the baby does not know what to suck or whether the fright reaction has discerned something truly frightening.

As Dewey argues about fear that it is not simply one impulse because:

Fear of the dark is different from fear of publicity, fear of the dentist from fear of ghosts, fear of conspicuous success from fear of humiliation, fear of a bat from fear of a bear. Cowardice, embarrassment, caution and reverence may all be regarded as forms of fear. ${ }^{49}$

Dewey explains elsewhere when he insists upon the plasticity of instinctual impulses such as fear being able to be formed in many different social habits:

In the case of the young it is patent that impulses are highly flexible starting points for activities which are diversified according to the ways in which they are used .... The actual outcome depends upon how the impulse of fear is interwoven with other impulses. This depends in turn upon the outlets and inhibitions supplied by the social environment. ${ }^{50}$

Psychologists have given up the attempt to explain human behavior and habits as the direct result of instinctual impulses. See, for example, Maslow, Abraham H. "Instinct Theory Reexamined," Motivation and Personality (1954). For almost any human instinctual impulse can be overridden or greatly modified though human learning Our instinctual impulses are not instincts as contemporary biology defines them: they are not complex patterns of unlearned behavior adapting individuals in a species to survival and reproduction.

48. John Dewey, and James H. Tufts, Ethics (New York: Henry Holt and Company, 1914), 38 .

49. Ibid., 154.

50. Ibid., 95 . 
So, there is a strong argument from the analysis of an impulse as being able, in Dewey's own words above, to "become organized into almost any disposition according to the way it interacts with surroundings." So Dewey is pointing to finding it almost impossible to explain human behavior or to identify human nature through the impulses of the individual alone. Consequently, when the baby's inchoate impulses are organized by parents and other significant adult others in the baby's life, the baby's behavior is structured into socially approved habits and roles, at first, with little or no self-control by the baby. These plastic impulses of the child give rise to desires and the end goals desired by the baby only insofar as the baby's cries are shaped by how the parents respond to the impulses of the child.

Nevertheless, it must be noted that Elizabeth Anderson in her encyclopedia article points out that Dewey specifically chooses "impulses as the original motor source of conduct," a view which she notes contrasts with "conventional desirebased psychology." Desires arise later as a child notices the consequences of "its impulsive activity". ${ }^{51}$ As Elizabeth Welchman sums up Dewey's critique of a desire based psychology of human nature,

Which desires a child will form and what the objects of those desires will be depends upon an interplay between impulse and environment. The human mind is not pre-equipped with latent desires waiting to be triggered by contact with their predetermined objects. Anything can be an object of desire provided the context is right. But in the absence of obstacles to action, we neither form nor act upon desires. Thus desires cannot be the motivational basis for all human action. They are instead just one kind of conduit through which impulsive drives are released. ${ }^{52}$

For Dewey, impulse comes first in prompting human actions, and desires develop as that impulse interacts with and is interacted upon by child's social environment especially. Perhaps a good example of an impulse which seems to break out into direct action would be the sexual impulse since it can be strong and spontaneous. Nevertheless, this sexual impulse, I would note, might be developed into many different sexual habits of behavior, or even some combination of these various possibilities, so the meaning or end-result of the impulse is not fixated by impulse but greatly influenced, as Dewey has already said, "according to the way it interacts with surroundings." What the writer of this article, Anderson and Welchman can agree upon is that all impulses, consequently, can be developed

51. Elizabeth Anderson, "Dewey's Moral Philosophy", The Stanford Encyclopedia of Philosophy (Spring 2014 Edition), Edward N. Zalta (ed.), https://stanford.io/2BqTnUb, (accessed 10 March 2018).

52. Elizabeth Welchman, "Dewey's Moral Philosophy," in The Cambridge Companion to Dewey, ed. Molly Cochran (New York: Cambridge University Press, 2010), 170. 
into various habits depending upon how these impulses are negated, affirmed, or moderated within a community's interaction.

\section{Conventional Morality}

Consequently, in conventional morality, when the developing child can understand the socially approved roles and standards of one's group, that child is more or less locked into those roles and standards and can hardly subject those ideals to a sustained criticism that carefully evaluates those ideals either from the socially approved roles and standards of another culture or from an unrealized but future community whose ideals may yet have not been realized. For example, if the child in one culture learns the socially approved role of being cruel to people of other ethnic groups, that child will have difficulty in understanding and evaluating another culture, either from an actual or from possibly a future community, where people of different ethnic groups are treated with respect.

\section{The Examined Stage of Morality}

Consequently, when the individual becomes more fully capable of critiquing the conventional social roles by seeing those roles from the viewpoint of other cultures and conventional groups or from the viewpoint of future, ideal communities, then the adolescent growing into a critical adulthood moves towards the critical level of morality. Such an individual can evaluate both one's own culture and the cultures of others in an ongoing process that constitutes the moral community of critical thinkers seeking better social roles and standards growing towards a universal community that can embrace all of these cultures insofar a wise integration can be accomplished. This evaluation of level (2) conventional morality should not be conceived of as an a priori judgment instituted by the reason of the self alone. Rather, all level (3) moral judgments of an individual are meant to be offered as hypotheses to the community for their further critique by the community and individual in the ongoing development of the moral community. In Dewey's Pragmatist theory of knowledge, all truths whether theoretical principles or practical moral guidelines are hypotheses that need to be tested. He affirms that "in the practice of science, knowledge is an affair of making sure, not of grasping antecedently given sureties. . . Truths already possessed may have practical or moral certainty, but logically they never lose a hypothetical quality." 53

These three levels of morality, namely, the pre-conventional, the conventional, and the examined, reveal that our human nature is found only partially in the

53. John Dewey, Later Works of John Dewey, Vol, I, 1925-1953, ed. Jo Ann Boydston (Carbondale, Il.: Southern Illinois University Press, 1981), 123. 
product of instinctual impulses and only partially in socially developed habits and roles, but most especially in and through a critical self-consciousness capable in an ongoing process of evaluating our pre-conventional, instinctual impulses and our earlier conventional social roles.

\section{The Focus of the Third Stage of Moral Development: Individual or Community?}

Having identified the three levels of moral development, the paper now turns to a further analysis of the third level. If we grant Dewey's thesis that human nature is not a fixed, unchanging reality but rather something that can be changed and developed through the creation of new social habits and new social roles, what should the focus of the development of the self, the individual, for example, in the individual's self fulfillment whether in this life or a next life that has a heavenly reward, or on something else than the mere individual? Dewey's answer is that our focus should not be on a conscious emphasis upon our selfdevelopment and our self-realization either for the self's sake, that is, upon how we feel when we have attained our goal, but upon our involvement in something richer than the present self, that is, upon the ongoing moral interaction of persons who are striving continuously to evaluate our pre-conventional and conventional selves.

Here is Dewey's argument. Whenever we consciously act, we are acting to achieve a goal or end. Either the word "end" can mean the end, final results of an action whether intended or not, or the word "end" can mean conscious aim of an agent. There is no doubt for Dewey that this conscious aim of an action necessarily includes the consciousness of some realization for the self who is the agent. However, Dewey argues that the focus upon one's own self-realization actually frustrates proper moral action. Proper moral action requires that an agent be focused upon some intended state of affairs in which the self is acting for something greater than the self. As Dewey writes: "For there is no way of discovering the nature of the self except in terms of objective ends which fulfill its capacities, and there is no way of realizing the self except as it is forgotten in devotion to these objective ends." ${ }^{44}$ For example, if a child were to fall into a well, proper moral action requires that the focus of the agent acting to save the child be precisely that of acting to save the child rather than upon the agent's own greater realization of one's own moral self in the eyes of others. Precisely because the agent who is risking one's life to save another may not survive in the rescue attempt, to focus directly upon one's own self-realization is to make it difficult to act for the aim of saving the life of the child. As Dewey writes in another example:

54. Dewey and Tufts, Ethics, 390. 
For example, the patriot who dies for his country may find in that devotion his own supreme self-realization, but none the less the aim of his act is precisely that for which he performs it: the conservation of his nation. $\mathrm{He}$ dies for his country, not for himself. He is what he would be in dying for his country, not in dying for himself. To say that his conscious aim is selfrealization is to put the cart before the horse. That his willingness to die for his country proves that his country's good is taken by him to constitute himself and his own good is true; but his aim is his country's good as constituting his self-realization, not the self-realization. . . . The problem of morality, upon the intellectual side, is the discovery of the self, in the objective end to be striven for, and then upon the overt practical side, it is the losing of the self in the endeavor for the objective realization. This is the lasting truth in the conception of self-abnegation, self-forgetfulness, disinterested [impartial] interest. ${ }^{55}$

An anonymous reader of this essay has well emphasized Dewey's general point above that self-realization should not be the focus of a person's moral endeavor even though the self is being realized or destroyed whenever we consciously act. As Dewey has written, "every good act realizes the selfhood of the agent who performs it; every bad act tends to the lowering or destruction of selfhood." 56 For, as Dewey continues, "this realization of selfhood in the right course of action is, however not the end of a moral act-that is, it is not the only end." 57 Robert Roth emphasizes Dewey's point: "Egoism is avoided, however, for Dewey states that if one adopts a selfish attitude in his relationships with others and makes self-realization a conscious aim, he would probably 'prevent full attention to those very relationships which bring about the wider development of self.'"58

Now, however, the question arises as to what we should be concentrating upon when we do not generally make self-realization our direct end. Dewey does not argue that we should have our focus only upon the self-realization of the community. For there can be times in our lives when we are doing some actions precisely "for the sake of acquiring more skill and power" as when we are

55. Ibid., 393-394

56. Ibid., 392.

57. Ibid., 393. While. Dewey and Tufts have positive things to say about selfrealization and ethics, this paper will be following the interpretation of Gregory Pappas in John Dewey's Ethics: Democracy as Experience where Pappas argues strongly against any grasp of Dewey's ethics as "an appeal to some ultimate good, such as selfrealization, human flourishing, or growth." Pappas, John Dewey's Ethics: Democracy as Experience, 302-303.

58. Robert Joseph Roth, "The Conditions for Self-Realization in the Philosophy of John Dewey," ETD Collection for Fordham University AAI6201041, 1961, 19, https://bit. ly/3eRRpL1. Dewey and Tufts. Ethics, 335. 
practicing the development of small acts of generosity, and there can be other times when we might refuse to do actions which generally are good for the community because the actions required for the good of the community might involve "an improper sacrifice of personal capacity." 59

Because of these exceptions to working towards the good of the community, we cannot say that the self-realization of the community is the only proper end of our third level of moral development. Every moral action will have effects both upon self-realization and upon the moral community's self-realization. At different times in our lives our focus needs to vary. Nevertheless, our broad moral aim should not be upon either the ready-made existing self or the ready-made existing community but upon the future development of both. However, even here in working towards the good of self and of others, Gregory Pappas points out that Dewey has suggested a significant comparison between the hedonistic paradox and the altruistic paradox. ${ }^{60}$ In the hedonistic paradox, happiness is the goal of life, but if we make it the focus of our conscious goal and striving, we find ourselves unable to attain happiness. In his chapter, "A Crisis in My Life," from his Autobiography, John Stuart Mill summed up one of the key things which he learned from his terrible depression when he was about 21:

I never, indeed, wavered in the conviction that happiness is the test of all rules of conduct, and the end of life. But I now thought that this end was only to be attained by not making it the direct end. Those only are happy (I thought) who have their minds fixed on some object other than their own happiness. . . . Aiming thus at something else, they find happiness by the way. ${ }^{61}$

In a parallel fashion, Dewey affirms that an individual needs to avoid making the good of others and even of the self the primary focus by an individual moral agent because:

... before he can really do good to others he must stop thinking about the welfare of others; he must see what the situation really calls for and go ahead with that, and the reason is the same in both cases. Whenever one makes his own good or the good of others the end, it becomes an extraneous end. ${ }^{62}$

59. Ibid, 394.

60. Pappas, John Dewey's Ethics: Democracy as Experience, 212.

61. John Stuart Mill, The Project Gutenberg Ebook of Autobiography, (2018), ch. V, https://bit.ly/3ihMKUF.

62. John Dewey, Lectures on Psychological and Political Ethics, 1898, ed. Daniel Koch (New York, N.Y.: Hafner Press, 1976), 214. See also: “As there is a 'hedonistic paradox,' namely that the way to get happiness is to forget it, to devote ourselves to things and persons about us; so there is a 'moralistic' paradox, that the way to get goodness is to cease to think of it - as something separate-and to devote ourselves to the realization 
In learning to develop habits of moral action, we may need in the beginning to focus upon our own self-development and/or upon the self-development of our associated community, but in the mature action of the moral self we need to focus upon the concrete steps we need to do in order to avoid the altruistic paradox. Yes, it is true that we have to study and practice the mechanics of moral self-realization in learning to do what is morally right and good for both ourselves and our associated community, but the best moral agents are those who forget themselves in the realization of something greater than themselves just as the greatest dancers and the greatest basketball players are those who forget themselves in the realization of the concrete tasks and interactions with others that can result in a great dance performance with others or a great basketball game with others.

\section{A Problem within the Third Stage of Moral Development: Self-Realization Confronting Death}

A problem of the relationship between self and the community can now be developed. Much moral speculation has been devoted to the problem, of equating personal happiness and regard for the general good. ${ }^{63}$ If I do what is morally right for justice and benevolence, will I necessarily be happy or rewarded with happiness? Some very bad people are happy, and some very good people suffer terribly. The problem thus put seems insoluble in this life and soluble only in the next life in which the bad will be punished and the good will be rewarded. However, Dewey and Tufts argue:

'the problem is insoluble because it is artificial.' It assumes a ready-made self and hence a ready-made type of satisfaction of happiness. It is not the business of moral theory to demonstrate the existence of mathematical equations, in this life or the next, between goodness and virtue. . . . To demand in advance of voluntary desire and deliberate choice that it be demonstrated that an individual shall get happiness in the measure of the rightness of his act, is to demand the obliteration of the essential factor in morality: the constant discovery, formation, and reformation of the self in the ends which an individual is called upon to sustain and develop in virtue of his membership in a social whole ${ }^{64}$

In reflecting upon this important quotation, we can note that all moral

of the full value of the practical situations in which we find ourselves. Men can really think of their 'duty' only when they are thinking of specific things to be done; to think of Duty at large or in the abstract is one of the best ways of avoiding doing it, or of doing it in a partial and perverted way," Dewey and Tufts Ethics, 353.

63. Ibid., $395 \mathrm{ff}$.

64. Ibid. 
reflection and action involves an evaluation of impulses, feelings, and social roles. For example, if a person does not reorder one's impulses towards revenge and hatred in subordination to the social order in which fair and impartial justice is to be sought through a fair trial, judged by one's peers, that person has failed the moral task of elevating justice to its more proper role in a democracy. Again, another example, if a person does not reorder one's impulses to selfishness in subordination to generous action that advances both self and others, then that person has failed the moral task of affirming the value of our common humanity. Moral evaluation and action need to revolve around the central value of our associated humanity and to subordinate impulses, feelings, and actions that either detract from or even fail to advance the invaluable value of our association and interaction, always aware, from the quotation above, "of the essential factor in morality: the constant discovery, formation, and reformation of the self in the ends which an individual is called upon to sustain and develop in virtue of his membership in a social whole." 65

In his summation of the topic, "Self-Realization as a Consequence of Moral Action," Dewey likewise affirms:

This conviction that at bottom and in the end, in spite of all temporary appearance to the contrary, the right act effects a realization of the self, is also evidenced in the common belief that virtue brings its own bliss. No matter how much suffering from physical loss or from material and mental inconvenience or loss of social repute virtue may bring with it, the quality of happiness that accompanies devotion to the right end is so unique, so invaluable, that pains and discomforts do not weigh in the balance. It is indeed possible to state this truth in such an exaggerated perspective that it becomes false; but taken just for what it is, it acknowledges that whatever harm or loss a right act may bring to the self in some of its aspects, - even extending to destruction of the bodily self, - the inmost moral self finds fulfillment and consequent happiness in the good. ${ }^{66}$

\section{Socrates on Self-Realization Confronting Death}

Having concluded with Dewey that moral evaluation and action generally involve reordering and subordination of impulses, feelings and action to the higher value of one's membership in a social whole, we may now reflect on the moral quandary of Socrates in being sentenced to death because, in Plato's view, he has lived the examined way of life for the virtues. My reading of Dewey and Socrates is guided by Dewey's acknowledgement of fourth meaning of Socrates' usage of "know thyself," found by Joseph Betz in:

Dewey's fourth treatment of the Socratic "know thyself" is in his 1908

65. Ibid.

66. Ibid., 392-393. 
"Intelligence and Morals", a public lecture delivered at Columbia University. He is once again writing to overcome an aspect of the classical tradition in philosophy. This time it is the inegalitarianism which Dewey finds in Plato and Aristotle. ... Dewey holds that only the man Who knows himself sharing a common destiny with all other men - not just his class or group is realizing the Socratic imperative to "know thyself". ${ }^{67}$

Dewey sees Socrates in opposition to the hierarchical structuring of society found in Plato and Aristotle and as deeply concerned with common destiny of all humans. My essay agrees with Betz that Socrates proclaiming "know thyself" to all humans is calling for all to lead the examined way of life and can be grasped as serving as a great exemplar of moral virtue in dying for the value of the examined ways life both in himself and in all humans.

As we shall see, Plato's representation of Socrates in The Apology favors an interpretation in which Socrates is uncertain of his personal immortality whereas the representation of Socrates by Plato in The Phaedo does seem to favor an interpretation in which Socrates definitely argues for the conclusion that the soul is immortal. For purposes of this paper, we shall interpret Socrates more in line with the view presented in The Apology in order to see how Socrates could be interpreted without belief in personal immortality in order to make a comparison with the reflections of John Dewey on moral development and the good of the moral community of humanity rather than to present a definitive study on Plato's understanding of Socrates or of Plato's affirmation of the immortality of the soul.

We turn, then, to the dilemma in The Apology between the mere desire to live and be with family and friends versus the desire to live the examined life. Like most human beings, Socrates desires to live and he desires to care for his family, however he does not merely wish to live and to care for his family. He has reformulated the desires of his life so that at the center of his desires is precisely the desire to live the examined way of life and the life of mutual respect in the virtues. His happiness and his self-realization are precisely to be found in his ongoing commitment to the examined way of life and the life of virtue. If need be, he will give up his mere physical life and his own personal care of his children for a greater good, the good of the moral community of self-examination and the life of virtue. He will ask his friends who live for the very same moral community of the examined way of life that they will care for his children and guide them towards the realization of that very same moral community. If there is a life after death, it can only be found in precisely that moral community of self-examination and of mutual respect in the virtues. Socrates does not need a life after death for him to find self-realization and happiness in that moral community for which he has lived in his adult commitment to the examined way of life. He is happy in

67. Joseph Betz, "Dewey and Socrates," Transactions of the Charles S. Peirce Society: A Quarterly Journal in American Philosophy, vol. 16, (1980): 354. 
being true to his moral principles even though he dies because he is convinced that a good person cannot be harmed either in life or in death. Yes, of course, there is some regret that he is dying; he would rather continue to live the examined way of life in community with others. The project of the examined way of life is never fully completed. Nevertheless, Socrates is as fulfilled as he can be in an ongoing process of the self-actualizing with others of the examined way of life and the life of mutual respect in virtue even though he dies in his attempt to realize that way of life. ${ }^{68}$ Moreover, Plato has Crito sum up the profound respect with which Socrates lived for others and the profound respect Socrates' partners in dialogue held for him at the conclusion of the Phaedo: "Such was the end, Echecrates, of our friend, who was, as we may say, of all those of his time whom we have known, the best and wisest and most righteous man." 69

Socrates in The Apology does reflect on whether death is an endless sleep from which we never awake or whether there is an afterlife which he envisions as a life where he would pursue the highest value of the examined way of life. His understanding of such a life after death is precisely that life for which he is willing to die since he cannot abandon that highest value in his mortal life now and at the same time regard the examined way of life as the defining choice of his life. ${ }^{70}$

To confirm this point in a thought experiment, we may try to imagine that the life after death focused upon the examined way of life could face such a great obstacle that Socrates would either have to be faithful to the examined life or have to give up such a great value in order to continue the life after death, it is clear that Socrates would stay committed to the examined way of life and the life of virtue and let go of the life after death. So, the key point is not that there is a life after death that supports and rewards the examined way of life but that living the examined way of life is its own reward in that it necessarily involves profound, mutual respect for all the partners, both self and others, in dialogue. Furthermore, if Socrates is not personally immortal because of his faithfulness to his great commitment, nevertheless he is objectively immortal in the memories of those who continue to live their lives with their central value being the very examined way of life and the necessary mutual respect for the partners in dialogue for which he perished. The examined way of life and the life of virtue which is inherently a life of mutual respect should be the most precious values and the source of our deepest happiness and satisfaction in our lives now even as they were in the life of Socrates.

Although, contrary to his doubt about life after death in The Apology, Socrates in The Phaedo affirms that he is as certain as he can be that after death that he will

68. Plato, Plato in Twelve Volumes, vol. 1 transl. Harold North Fowler; Introduction by W.R.M. Lamb (Cambridge, MA, Harvard University Press; London, William Heinemann Ltd. 1966), http://www.perseus.tufts.edu/hopper/text (accessed 10 March 2018) Apology 37e, 41d-e.

69. Ibid., .Phaedo 118a.

70. Ibid., Apology, 40b-42. 
be with the gods who are wise and good, it is worth our while to point out the connection in his attitude toward being a philosopher and being unafraid of death, Socrates affirms that the philosopher should not be afraid of death since the philosopher is ever pursuing death and dying since the philosopher is living the examined way of life. It is clear that the Phaedo has a strong argument for the immortality of the soul since Socrates and Simmias in their dialogue reach the conclusion that death frees and separates the soul from the body and that it is central to the philosopher's goal throughout one's life to draw the attention of the philosopher away from the sensible to the intellectual. ${ }^{71}$ Of course, it is clear, as Joseph Betz argued, that the description of the philosopher's activity as "always abstracting his thought away from the sensible and pursuing the lasting definition of the essences of things sensed" is precisely what John Dewey was opposed to in Greek philosophy. ${ }^{72}$ As a pragmatist philosopher, profoundly influenced by Darwin's evolutionary perspective and evidences, Dewey holds that structures of human society and any ideal moral developments of those structures are not rooted in eternal essences but are always subject to change and development. ${ }^{73}$

Nevertheless, there are passages in The Phaedo which weaken the strength of the conclusion which Socrates and Simmias draw about the immortality of the soul. Dylan Futter makes three points in his analysis of Socrates. ${ }^{74}$ First, Socrates himself states in The Phaedo that he has a positive attitude toward death because he has "hope that there is something for those who have died, and as has long been said, a much better future for the good than for the wicked."75 (Phaedo 63c47]. But hope in immortality involves recognition of the fact that immortality is uncertain. Second, Socrates himself also affirms that he is uncertain of immortality:

For I am thinking ... that if what I say is true, it is a fine thing to be convinced; if, on the other hand, nothing exists after death, at least for this time before I die I shall distress those present less with lamentations, and my folly will not continue to exist along with me-that would be a bad thing-but will come to an end in a short time. Thus prepared, Simmias and Cebes ... I come to deal with your argument. ${ }^{76}$

And third, at the conclusion of the Phaedo, after the death of Socrates, the text states: "Shortly afterwards Socrates made a movement; the man uncovered him;

71. Ibid., Phaedo, 67d-68e.

72. Betz, "Dewey and Socrates," 39-40.

73. John Dewey, The Influence of Darwin on Philosophy and Other Essays in Contemporary Thought (NY: Henry Holt and Company, 1910): 1-19.

74. Dylan Brian Futter, "The Death of Socrates," Philosophical Papers, 44, no. 1 (March 2015) . 42-44.

75. Plato, Phaedo 63c4-7.

76. Ibid., 91b1-8. 
he had fixed his eyes. Seeing this Crito closed his mouth and his eyes." 77 Futter interprets that this passage leads to the conclusion that the courage of Socrates in facing death is grounded not on the certainty of immortality, but on the knowledge of ignorance because "[ $t$ ]he image of open mouth and eyes is a trope for wonder. In wonder we become aware of ourselves as not-knowing. Thus it seems that Socrates died as he had lived, a life of perpetual aporia and wonder."78 Futter's analysis of these three passages from The Phaedo does permit us to emphasize the passages from The Apology in which Socrates clearly professes his ignorance about what comes after death, whether it be an eternal sleep or the immortality of the soul of Socrates.

Consequently, in this paper, we will now adapt the argument of Socrates on the central task of the philosopher without using the conclusion which Plato is affirming about the immortality of the soul. The Phaedo has essentially argued that the philosopher is always abstracting his thought away from the sensible and pursuing the lasting definition of the essences of things sensed. So, in a parallel manner, we may point out that the philosopher in making wise moral decisions does not base a decision merely upon what happens to be desired or merely what happens to be approved of by one's fellow citizens but upon the more lasting moral values which Socrates never fully possesses but of which he is always in search. Consequently what is central to one's actualization and fulfillment of moral values is the examined way of life which is always a continuing journey. Ambury offers support of this grasp of the continuing journey of the examined way of life as central to the ethical life leading to human self-actualization, that is, to happiness, interpreting Socrates as a proponent of eudaimonism:

There are a number of passages in the Apology that seem to indicate that the greatest good for a human being is having philosophical conversation (36b-d, 37e-38a, 40e-41c). Meno 87c-89a suggests that knowledge of the good guides the soul toward happiness (cf. Euthydemus 278e-282a). ${ }^{79}$ [Ambury, The Internet Encyclopedia of Philosophy].

Consequently, the dying of Socrates for the central moral value of his life, the examined way of life, is not unique as a moral decision. On the contrary, it is a moral decision that exemplifies what should be going on in moral decisions all the time, that is, precisely the subordination of earlier felt desires and impulses and social roles from babyhood and childhood to the highest moral ideals of the examined way of life and the life of mutual respect in the virtues. This paper's interpretation of Socrates is similar to that of Gadamer, as pointed out by Ambury.

77. Ibid., 118a.

78. Futter,"The Death of Socrates," 44.

79. James M. Ambury,"Socrates," The Internet Encyclopedia of Philosophy, http://www. ieutm.edu/, (accessed 10 March 2018). 
For Gadamer finds that the examined way of life, especially in Socratic questioning, to be a key part of the ethical way of life. It is not that Socrates engages in dialogue about the virtues, but that this engagement in dialogue with others is a necessary condition for the partners in dialogue to become ethical, that is, to become partners whose dialogue is an essential component of their mutual respect for each other "because without asking questions as Socrates does, we will not be ethical." 80 Socrates has always subordinated his life of sensation and emotion to the more lasting values of morality as founded in mutual dialogue, and he is more deeply happy in finding his self-realization in striving to realize something greater than himself, the moral community of self-examination and of virtue which includes realization of both self and others, than in merely continuing to live.

As Dewey has written:

it is the business of people to develop such capacities and desires, such selves as render them capable of finding their own satisfaction, their invaluable value, in fulfilling the [highest moral] demands which grow out of their associated life....

Our final word about the place of the self in the moral life is, then, that the problem of morality [and happiness] is the formation out of the body of original instinctive impulses which compose the natural self of a voluntary self in which socialized desires and affections are dominant, and in which the last and controlling deliberation is the love of the objects [most especially, namely, the community of self-examination and moral virtue] which make this transformation possible. ${ }^{81}$

Dewey, of course, does not appeal to any Kantian ideal that governs all moral thought as an a priori absolute independent of our developing self and developing communities, rather Dewey emphasizes our moral aim as forming, in the quotation above, "a voluntary self in which socialized desires and affections are dominant and in which the last and controlling deliberation is the love of objects," most especially, the ongoing community of self-examination and of moral virtue. Precisely this community is worthy of a person's pervasive and final dedication in one's life and death.

80. Ibid.

81. Dewey and Tufts, Ethics, 396-397. 


\section{Conclusion}

The purpose of the paper has been to examine how John Dewey understands the third stage of moral development, the examined stage of morality, as devoted to a good which recognizes that the self has arisen through control of one's impulses through one's membership in one's original family community and which can develop into an ongoing critique of one's present community through interactions both with other already existing and also future ideal communities. We have focused not on the ready-made self or the ready-made community but upon the developing moral self and the developing moral community. Even here, Dewey warns us that just as we should avoid the hedonistic paradox, we should also avoid the altruistic paradox. We have considered Dewey's proposed analysis of the three stages of moral development: (1) the premoral stage in which the infant has uncoordinated instinctual impulses which need guidance from the parenting adults into, (2) the customary stage of morality in which the child and/or adolescent must adopt uncritically, more or less, the habits and outlook of that child's social group, and (3) the critical stage of morality in which the individual may examine the pros and cons of those customary social habits and outlook, seeking a morality of habits and outlook that may be an improvement upon the earlier adopted habits both for the self and for community. So, for example, if a child has adopted from one's social group the habit of disparaging the dignity and humanity of another group of humans, it is possible for the young adult to examine such prejudice critically and to find the invaluable value of all humans.

In this third stage of critical morality, Dewey has argued that moral fulfillment is to be found, not in focusing upon one's self-realization as the ultimate end of human action and not in focusing upon a community of moral agents who all participate in the invaluable value of humanity, but rather upon the concrete tasks in serving the specific goods of others and the self. Sometimes one's moral actions may focus upon the self's development and other times more on the community's developing. Nevertheless, just as one's action as a basketball player or as a dancer is diminished in the long run by concentration upon one's own action and fulfilment except when one is first learning to dribble or to shoot the ball or one is first learning the proper dance steps and basics of coordination with one's partner but later is enhanced greatly in the long run by a focus upon the greater good of one's team or upon one's dance partner, so also one's achievement in morality is crippled by excessive focus upon one's self-realization of good moral habits except when one is first learning to practice the virtues but later is enhanced by a focus that involves a full consideration of the ongoing moral development of others in the community. Even here, Dewey has warned us of the altruistic paradox when we would focus upon the self-realization of the community, affirming instead that we need to focus upon the concrete goods of the community that we intend to assist. 
It is precisely this focus of the more mature self upon a good in which the value of the self is intertwined with the value of others in an ongoing and developing community that allows Dewey to argue that the moral of the self can be found intertwined with others even though the moral self may die precisely because one's dedication to the interlacing good of self and others in the moral community in which the invaluable value of all moral agents is the goal and because this community of value continues on after the death of the individual.

The paper concludes with an analysis of Dewey and of Socrates, finding that both affirm that the morally mature individual in what Dewey has named the third stage of moral development is one who is always critiquing one's own socially acquired habits in search of an ongoing transformation of both the self and one's community. Moral behavior is not to be evaluated by one's own self as to whether or not it leads to some external reward, like a pay raise in this life or even an immortal life of happiness after death or even in self-realization, rather the moral life is precisely the transformation of the self from any supposed focus upon individual instinctual impulses or individual emotional wants and needs of one's original family group into a focus upon a good in which the self's value is intertwined with the development of others, namely, the moral community of the invaluable value of all moral agents. It is in this invaluable value of all moral agents that releases the self from excessive focus upon the self and for the proper focus upon the precious value of self and other in the mutually enriching community of moral agents.

To contrast Dewey and Socrates, we may note that Socrates has affirmed that the philosopher should not be afraid of death since the philosopher is ever pursuing death and dying since the philosopher is living the examined way of life, always abstracting his thought away from the sensible and pursuing the lasting definition of the essences of things sensed. Of course, Dewey has rejected the Platonic interpretation of Socrates which would assume eternal forms and an eternal, immortal soul reuniting with these forms through death. As with things that are sensed so also with things that are desired, we have only argued that the philosopher, for Socrates, is not seeking what is merely desired on a sensory level but what is desired after a critical examination of what is truly worthwhile, namely, the examined way of life and the life of mutual respect in virtues worthy of being shared by all humanity. So, for Socrates, his dying for the central moral value of his life, the examined way of life, is not unique as a moral decision. On the contrary, it is a moral decision that exemplifies what should be going on in moral decisions all the time, that is, precisely the subordination of earlier felt desires and impulses and social roles from babyhood and childhood, even the very desire to continue one's physical life, to the higher moral ideals of the examined way of life and the life of mutual respect in the virtues. Socrates has always subordinated his life of sensation and emotion to the more lasting values of morality which are founded in mutual respect, and he is more deeply happy in finding his self-realization in striving to realize something greater than himself, 
the ever-developing moral community of self-examination and of mutual respect in virtue rather than in merely continuing to live.

So also for John Dewey we have emphasized his analysis of the third stage of morality, the examined stage, precisely as the stage not in which the self seeks an external happiness in this life or the next for one's morally good actions, but as the stage in which self-realization of the moral self is to be found in dedication to a community of moral agents greater than the self but also including the self, namely, the community in which the mutual and invaluable value of all moral agents is the end result but not the primary focus as the ultimate goal of all our moral action. The goal to focus upon is the concrete tasks in serving the specific goods of others and the self. In this community there is, as Dewey has emphasized, "the constant discovery, formation, and reformation of the self in the ends which an individual is called upon to sustain and develop in virtue of one's membership in a social whole." ${ }^{82}$

\section{Bibliography}

Ambury, James M. "Socrates," The Internet Encyclopedia of Philosophy. http://www. ieutm.edu. Accessed 10 March 2018. ISSN: 2161-0002.

Anderson, Elizabeth. "Dewey's Moral Philosophy." The Stanford Encyclopedia of Philosophy (Spring 2014 Edition), edited by Edward N. Zalta. https://stanford. io/2ZnHBSE. Accessed 10 March 2018.

Betz, Joseph. "Dewey and Socrates." Transactions of the Charles S. Peirce Society: A Quarterly Journal in American Philosophy, 16, (Sept. 1980): 329-356.

Dewey, John. Human Nature and Conduct: An introduction to social psychology. NY: Henry Holt and Company, 1922.

Dewey, John. The Influence of Darwin on Philosophy and Other Essays in Contemporary Thought. NY: Henry Holt and Company, 1910.

Dewey, John. Lectures on Psychological and Political Ethics, 1898, edited by Daniel Koch. New York, N.Y.: Hafner Press, 1976.

Dewey, John. Later Works of John Dewey, Vol, I, 1925-1953, edited by Jo Ann

Boydston. Carbondale, Il.: Southern Illinois University Press, 1981.

Dewey, John, and James H. Tufts. Ethics. New York: Henry Holt and Company, 1914.

Futter, Dylan Brian. "The Death of Socrates." Philosophical Papers, 44, no. 1 (March 2015): 39-51.

Maslow, Abraham H. "Instinct Theory Reexamined." Motivation and Personality. New York: Harper \& Row, 1954.

Mill, John Stuart. The Project Gutenberg Ebook of Autobiography, 2018. https://bit.ly/ 31yo44D.

82. Ibid., 395. 
Pappas, Gregory. John Dewey's Ethics: Democracy as Experience. Bloomington: Indiana University Press, 2008.

Plato. Plato in Twelve Volumes, vol. 1, translated by Harold North Fowler. Introduction by W.R.M. Lamb. Cambridge, MA, Harvard University Press; London, William Heinemann Ltd, 1966. https://bit.ly/2CZgeXt. Accessed 10 March 2018.

Roth, Robert Joseph. "The Conditions for Self-Realization in the Philosophy of John Dewey." ETD Collection for Fordham University AAI6201041, 1961. https:// bit.ly/2Akc8YR.

Welchman, Elizabeth. "Dewey's Moral Philosophy." In The Cambridge Companion to Dewey, edited by Molly Cochran. New York: Cambridge University Press, 2010. 


\title{
Images of Animals in Neolithic Chinese Ceramic
}

\author{
By Bogna Łakomska*
}

\begin{abstract}
The images of animals or their (more or less) stylised motifs once depicted in the form of painting and sculpture, and nowadays through various media, have many stories to tell. Their ancient images point to the undeniably great role that animals played in human life. The rich material culture, as well as the written sources we have today, enables us to examine - both in physical and spiritual terms - the coexistence and co-creation of the worlds of people and animals in the region that we now call China. General animal research, especially within Europe, usually concerns spatial and physical differences; animals from ancient, medieval and early modern times are researched in the context of their utilitarian role, as well as their exoticism, discovering new species and deepening knowledge about those already known to man. Creating a picture of the animal images in Chinese Neolithic art, I hope to present various social and political practices that have influenced the acquisition of knowledge about animals, and thus to discover their role in human life. Chinese animal studies to date in pre-dynastic and dynastic eras regularly focus on animals as spiritual beings and sources of nutrition. It is worth looking at the significance of animals from a different angle - from the perspective of art, which can inform us about animals and people in the context of religion, magic, symbols, aesthetics and the spiritual life of both. My article focuses particularly on the decorative motifs appearing in ceramics of three Neolithic cultures: Yangshao 4000-3000 BC, Нетudu 5500-3300 BC and Longshan 2500-1900 BC.
\end{abstract}

\section{Introduction}

The history of animal images in art probably begins in the Palaeolithic period (about 32,000 years ago) when on the walls of numerous corridors in what is now the Chauvet Cave in the Ardèche river valley in France, man created more than three hundred paintings depicting various species of animals. Giovanni Aloi suggests that it could have been some sort of reference for understanding animals, although he does not exclude other widely accepted theses, one of which hypothesises of the divinational nature of these images to enable successful hunting, while another supposes a spiritual element born as a result of shamanic practices referring not so much to the animals themselves as to their spirits. ${ }^{1}$ Regardless of the reasons that guided the authors of the paintings, Aloi notices that the animal images painted over thousands of years generally fell into two very extreme categories: food and deities.

The images of animals or their (more or less) stylised patterns once depicted in the form of painting and sculpture, and nowadays with the use of various

\footnotetext{
"Associate Professor, Academy of Fine Arts in Gdańsk, Poland.

1. Giovanni Aloi, Art and Animals (London-New York: I.B. Tauris, 2012), 3.
} 
media have many interesting stories to tell. It is thanks to them that we can learn about species of elephants that disappeared centuries ago, or the growing importance of horses or water buffaloes. Their ancient images point to the undeniably major role that animals played in human life. The rich material culture, as well as the written sources that we have today, enables us to examine both in physical and spiritual terms - the coexistence and co-creation of the worlds of people and animals in the region that we now call China. ${ }^{2}$

For many cultures and social groups in ancient China, as well as later dynastic times, animals were the link connecting the world of people with the cosmos; therefore, animal caretakers were eagerly employed as fortune-tellers and advisers at royal and imperial courts. ${ }^{3}$ Indeed, shamans were the ones who probably exercised supreme political power over individual social groups in the first centuries of the Chinese civilisation. ${ }^{4}$ From the shells of turtles, traces of snakes or birds, they read the announcement of some events, thanks to which they were able to "manage the present". ${ }^{5}$ This is how Chinese writing is thought to have been created - thanks to the inspiration of the mythological official Cangjie 倉頡 in the traces of birds and other animals. ${ }^{6}$

Perhaps the oldest images of animals in Chinese art are represented by Neolithic petroglyphs carved in various parts of China. Their creators, using the natural space, were in no way bound by the frames to which the composition should be matched. The concept of the "frame" only developed along with the launch of ceramic manufactories or skeletal architecture. ${ }^{7}$

2. Roel Sterckx, Martina Siebert, Dagmar Schäfer, Animals Through Chinese History. Earliest Times to 1911 (Cambridge: Cambridge University Press, 2011), 3.

3. T. Thomas Allsen, The Royal Hunt in Eurasian History (Philadelphia: University of Pennsylvania Press 2006), 145.

4. Bogna Łakomska, Kolekcjonerstwo w Chinach. Do XII wieku/Collecting in China. Until 12 century AD (Warszawa-Toruń: Polish Institute of World Art Studies \& Tako Publishing House, 2015), 23. Compare with Chang Kwang-Chih, "China on the Eve of the Historical Period," in The Cambridge History of Ancient China: from Origins of Civilisation to 221 B.C. ed. Michael Loewe, Edward L. Shaughnessy (Cambridge University Press, 1999), 61-63.

5. Lisa Raphals, Divination and Prediction in Early China and Ancient Greece (Cambridge: Cambridge University Press, 2013), 143, 173.

6. Sterckx, Siebert, Schäfer, Animals Through Chinese History. Earliest Times to 1911, 6.

7. Hung $\mathrm{Wu}$, "The origins of Chinese painting (Paleolithic Period to Tang Dynasty)" in Three thousand years of Chinese painting (New Haven\& London: Yale University Press; Beijing: Foreign Languages Press, 1997), 17. 


\section{Decorative Motifs of Fish, Human Masks and Bird}

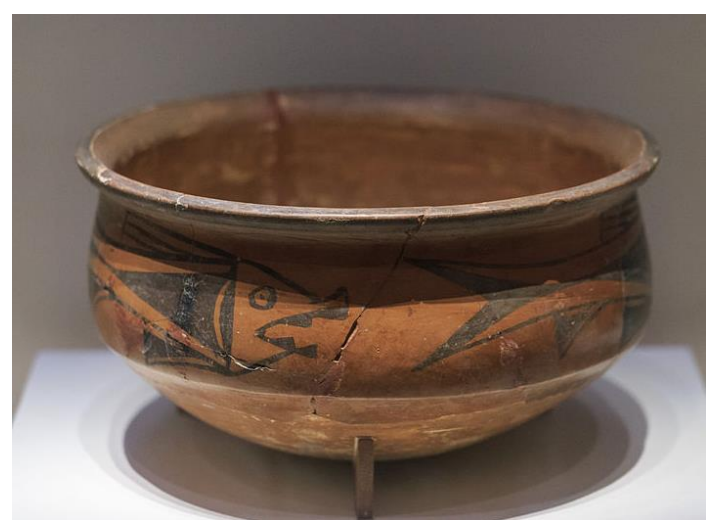

Figure 1. Pottery bowl painted with fish decoration. Yangshao Culture, Banpo style (48004300 BC). Archaeological site: Banpo village, Shaanxi. National Museum of China, Beijing Photography: Bogna Łakomska

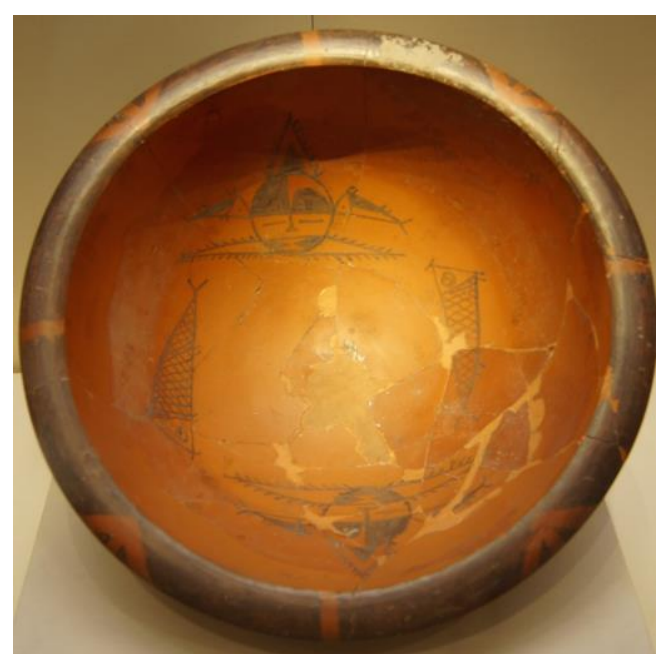

Figure 2. Pottery bowl painted with human faced fish decoration. Yangshao Culture, Banpo style (4800-4300 BC). Archaeological site: Banpo village, Shaanxi. Capital Museum, Beijing

Photography: Bogna Łakomska

The earliest ceramic decorations using animal motifs include patterns decorating dishes from the Yangshao 仰韶 culture (5000-3000 BC). ${ }^{8}$ Among the

8. Yangshao culture developed in quite extensive areas covering the middle and lower course of the Yellow River (today's Shaanxi, Hebei and Henan provinces), the southern and middle course of the Hanshui River 漢水 (today's Hubei Province) and the Tao 洮 River (today's Gansu Province). For more on Yangshao Culture, see: Zhang Zhongpei, "The Yangshao Period. Prosperity and transformation of prehistoric society" in Sarah Allan (ed.), The Formation of Chinese Civilization. An Archaeological Perspective (New Haven and London: Yale University Press, Beijing: New World Press, 2005), 45-83. For encyclopaedic information about ceramics from the Yangshao culture, see: Suzanne G. 
many objects from that time, the objects discovered in the village of Banpo 半坡 near the city of Xi'an 西安 deserve special attention. They are characterised by high-class artistry, especially in the context of design, which was probably made using some flexible brush-like tools. This assumption arises from the fact that the black patterns on the orange terracotta walls were made with very smooth tapering lines here and there, often with rounded ends. Some of the decorative motifs are quite realistic while others are schematic and reduced to almost abstract signs. ${ }^{9}$ The power of expression typical of many performances evokes delight. A great example of this is a terracotta bowl decorated on the outside with a drawing of three fish giving the impression of moving in the water (Figure 1). This suggestive movement is emphasised by clearly marked fins and wide-open mouths, revealing fairly prominent teeth. However, more important than aesthetic values seems to be the symbolic and religious meaning of the Banpo ceramic decoration. Fisheries certainly played an important role in the life of the local community, as evidenced by the numerous fish-catching tools discovered by archaeologists. Successful fishing guaranteed food, and thus joy of life, which is why the fish with its reproductive capacity symbolised not only prosperity but also fertility. It seems, therefore, that the fish ornamentation on the walls of the vessels served as divination to evoke happiness. This type of hypothesis seems particularly accurate in connection with a number of terracotta bowls decorated on the bottom with fish motifs as well as images of a human face (Figure 2). The bowl from the Chinese National Museum in Beijing is an excellent example of this. It is decorated with four symmetrically composed drawings of two fish and two faces/masks flanked at the ears with smaller forms of fish. Round masks alternate with schematically treated fish seen on one side only. Looking more closely, one may see that the fish point counter clockwise, while the masks look as if they were their mirror image. All this brings to mind a spell, and also indicates borrowings made by Chinese decorators. Indeed, very similar patterns using the motif of fish flowing in a counter-clockwise direction can be seen on the Neolithic ceramics from Samarra (an area of ancient Mesopotamia) (Figure 3). Modern researchers have no doubt that Chinese pottery culture owes much to the older civilisation of Mesopotamia. ${ }^{10}$

Valenstein, Handbook of Chinese Ceramics. Revised and enlarged edition, (New York: Metropolitan Museum of Art), 1989, 3-8.

9. Liu Jing, "Bowl with a fish motif" (Polish translation: Katarzyna Maleszko) in 5000 lat sztuki chińskiej/ 5000 years of Chinese art (Warszawa: Arkady Publishing House 2014), 14; Jing Zhao, "The bowl decorated with three fish motif" (Polish translation: Katarzyna Maleszko). In 5000 lat sztuki chińskiej/ 5000 years of Chinese art (Warszawa: Arkady Publishing House 2014), 15.

10. Hugo Munsterberg, Arts of China (Tuttle Publishing, 2011), 21. 


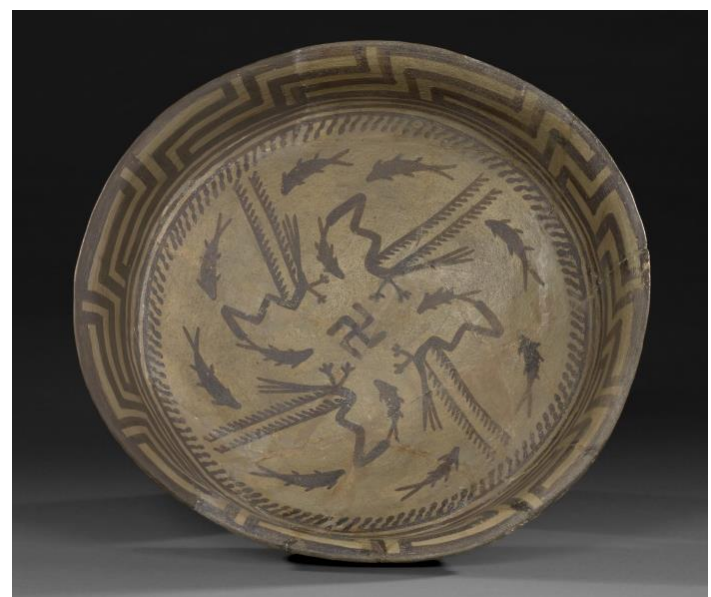

Figure 3. Samarra Plate painted with fish decoration. Iraq, c. 5000 BC. Vorderasiatisches Museum, Berlin

Source: https://bit.ly/2V6DRUi.

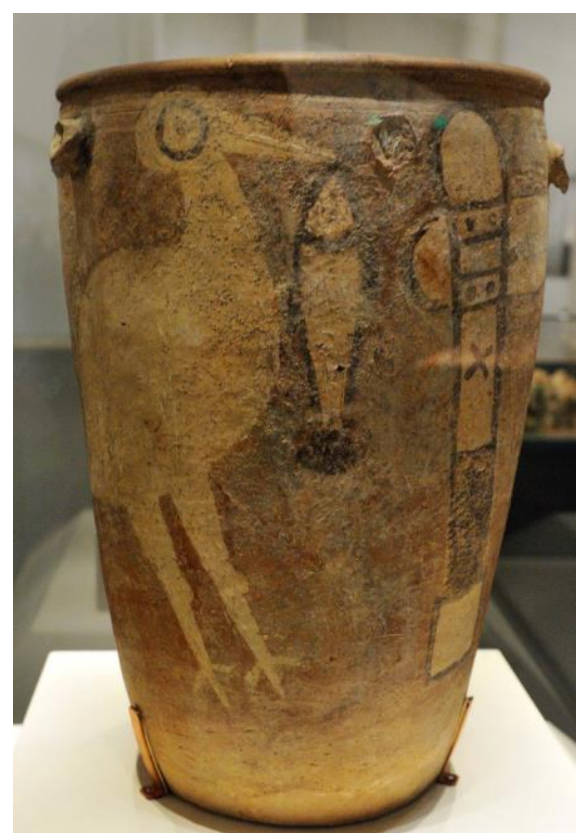

Figure 4. Pottery jar painted with a heron (?) with a fish and stone axe. Yangshao Culture (5000-3000 BC). Archaeological site: Yancun Village, Henan. National Museum of China, Beijing

Photography: Bogna Łakomska

The fish motif also appears on the outer walls of a terracotta pitcher from the Yangshao culture (the so-called Miaodigou period 廟底溝 4000-3000 BC) discovered in the village of Yancun 閻 村 near Linru 臨汝 in Henan province 
(Figure 4). ${ }^{11}$ This time, however, in addition to fish, there is a colourful decoration featuring a heron ${ }^{12}$ and an axe. The bird painted with white paint is probably the most eye-catching element in the whole composition. Featured in profile, it stands on slightly oblique legs holding a fish in its beak. Stiff limbs painted at an angle give the impression of tension and the heron's large round eye signals concentration and intensity of emotions. One may form the impression that it cost the bird some effort to catch a large fish. Apart from the rather suggestive way of presenting the heron and passive fish, it seems that the overall composition is totemic. ${ }^{13}$ There is a presumption that the images of birds were considered protective symbols of tribes, especially those who once inhabited the lower course of the Yellow River. In turn, a painted stone axe with a handle wrapped in fabric (or leather) and decorated with geometric patterns could be a symbol of status and power. Tools of this type were used for ritual purposes to sacrifice food for ancestors. ${ }^{14}$

In addition to the interesting subject matter, this scene undoubtedly deserves attention for purely artistic reasons. The image of a heron catching a fish is certainly the result of careful observation of the world. All elements of this composition indicate that this is not so much a pattern as an individual work of a unique character distinct from other decorations made with black paint according to a specific model.

\section{Pig Masks}

Slightly later (c. 3000 BC), although also associated with the Yangshao culture, comes the painting decoration of a terracotta pitcher discovered in Wangjiayinwa 王家陰窪 (Qin'an 秦安, Gansu Province) (Figure 5). ${ }^{15}$ The decoration of the gourd-shaped vessel is made of two patterns of pig masks

11. One of the objects on the list of Chinese cultural monuments protected by law against export abroad and any exhibition there. See: China Cultural Heritage Protection Website 彩绘鹳鱼石斧图陶缸https://bit.ly/314BuF7 (access: 0410 2019).

12. Contrary to popular belief that the painting shows a stork or a crane, I am of the opinion that this is a heron feeding on fish.

13. Lili Fang, Chinese Ceramics (Cambridge University Press, 2011), 10. However, there are scholars who question the theories about totemism in prehistoric China. See: Yang Xiaoneng, Reflections of Early China: Décor, Pictographs, and Pictorial Inscriptions (Seattle and London: The University of Washington Press, 2000), 82. This does not change the fact that there is still a lack of specific explanations in this regard.

14. Examples of Neolithic stone ritual tools see: Jessica Rawson, "Jades and bronzes for ritual" in The British Museum Book of Chinese art, ed. Jessica Rawson (London: British Museum Press, 1996, reprint from 1992), 44-45.

15. E. Jun (ed.) Masterpieces from the Gansu Provincial Museum (Lanzhou: Gansu Provincial Museum 2006), 33, 52. 
joined by a common eye. They were painted with brown paint on the upper part of the belly, on both sides of the pitcher. Stylistically similar decorations in the form of animal masks were found on dishes discovered in Jiangzhai 姜寨 (Lintong County 臨潼, Shaanxi Province). They are probably totem-style patterns indicating the significant importance of this animal for local communities.

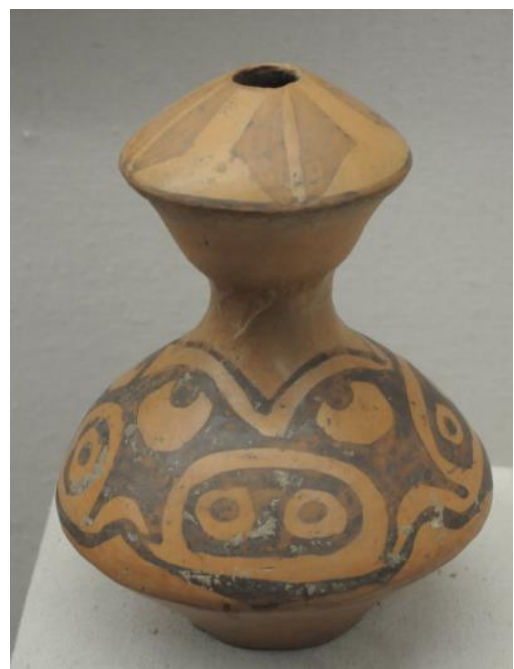

Figure 5. Painted gourd-shaped pottery vessel with a pig-mask design. Yangshao culture (5000-3000 BC). Archaeological site: Wangjiayinwa, Gansu. Gansu Provincial Museum Photography: Bogna Łakomska

People domesticated the pig in China some 8,000-6,000 BC. in order to have access to meat without hunting. ${ }^{16}$ Wild pigs living near human settlements were easily enslaved, giving them food from surpluses of cultivated cereals in return. They became an indicator of prosperity and happiness, which people also strove to achieve and maintain in the afterlife. Hence, the dead at their burial sites were often accompanied by amulets made of pig bones or figurines of pigs moulded from clay. This animal provided "protection" for the family, its breeding did not require any special skills and did not pose too many problems, so as a creature useful to humans, not too demanding and constantly accompanying them, it became an artistic motif repeatedly used in various configurations. The vase decoration from Wangjiayinwa recalls stage makeup so much so that it is worth considering the theory whether the form of the pig mask is not associated with shamanic rituals in which it was necessary to paint the face as an animal.

16. Archaeological discoveries from Zengpiyan 甑皮岩 in Guilin 桂林 (Guangxi province 廣西) or Cishan 磁山 in Wu'an 武安 County (Hebei Province) are to prove this. Joshua J. Mark, "Pigs in Ancient China," in Ancient History Encyclopedia (24 January 2019), https://bit.ly/37SuSuV. 


\section{Giant-salamander, Snake and Frog Designs}

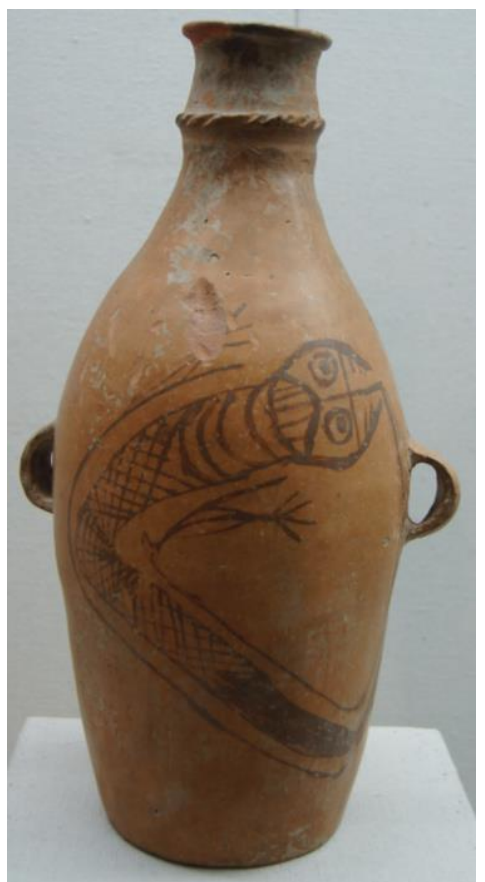

Figure 6. Painted pottery vase with a giant-salamander design. Archaeological site: Xiping, Gansu. Yangshao culture, dated around 3200 BC. Gansu Provincial Museum Photography: Bogna Łakomska

A much more expressive approach is characterised by the representation of a giant salamander made with black paint on the longitudinal belly of a terracotta vase discovered in Xiping 西平 (Gangu 甘谷 County in Gansu Province) also associated with the development of the Yangshao culture and dated around 3200 BC (Figure 6). ${ }^{17}$ The whole looks like a hastily made sketch; the lines overlap in places as if the author was not entirely sure of his/her movements. In any case, he/she implied that this is an extremely long and flexible animal, capable of touching the top of its head with its tail. Indeed, giant salamanders (Andrias davidianus) reach up to 1.8 meters in length and are able to bend their body to an impressive extent. It is one of the largest living amphibians, practically unchanged since the time of the dinosaurs. Unfortunately, today it is a critically endangered species due to overexploitation, environmental pollution, and thus numerous diseases and loss of habitats. Once, the giant salamanders inhabited numerous mountain rivers and lakes in central and southern China, and today they occur extremely rarely in their natural habitat. This animal has a large flattened head, small eyes

17. E Jun, Masterpieces from the Gansu Provincial Museum, 33, 56. 
without eyelids and a wide mouth. Its skin is wrinkled and is distinguished by a spotted pattern, which, as can be seen, the author of the Xiping vase decoration also tried to express. For some reason, however, he/she decided to paint the salamander with huge eyes and frighteningly large teeth. Since this is one of the many representations of the giant salamander in the decoration of Yangshao ceramics, it is likely that it was a tribe's totem or some other form of manifestation of attachment to that animal. And since the animal's head resembles a human head, some scholars are of the opinion that it may be the image of Fuxi 伏羲 - the legendary ancestor and monarch of all Chinese depicted with a human head and body of a snake.18

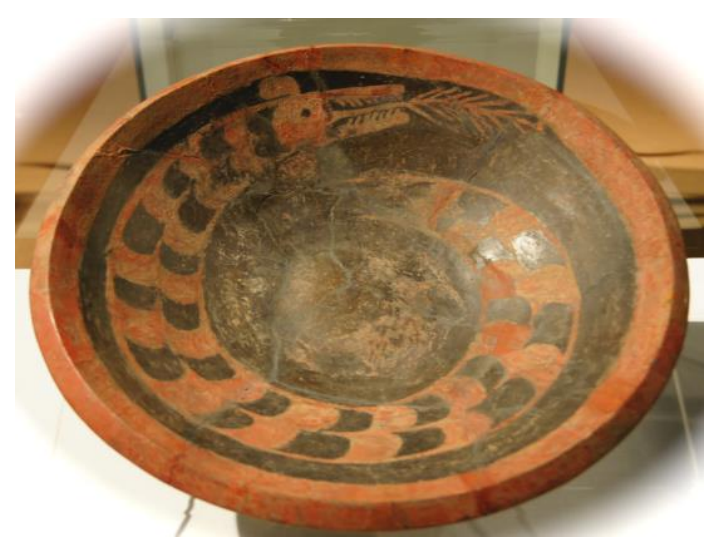

Figure 7. Painted pottery basin with a snake design. Archaeological site: Taosi, Shanxi. Longshan culture (2500-1900 BC). The Institute of Archaeology, Chinese Academy of Social Sciences, Beijing

Photography: Bogna Łakomska

The snake motif in Chinese painting on ceramics also occurs in the Neolithic era. One of the oldest images of this type is the pattern painted inside a shallow bowl discovered in a tomb in Taosi 陶寺 (Xiangfen County 襄汾, Shanxi Province) in the area of Longshan Culture (2500-1900 BC) (Figure 7). ${ }^{19}$ The terracotta dish could have been a platter or a type of washbasin, albeit rather symbolic and intended only for the use of the grave owner in which the object was found. This suggestion results from the fact that the bowl was fired at a fairly low temperature, and the painting decoration was made only after firing, which calls into question the usefulness of the object in everyday life. ${ }^{20}$

18. Ibid, 33.

19. Behzad Bavarian and Lisa Reiner, Ceramic's Influence on Chinese Bronze Development (Dept. of MSEM College of Engineering and Computer Science September 2007), 8-9.

20. Brian Hogarth, The golden age of Chinese archaeology. Celebrated discoveries from the People's Republic of China (Washington: National Gallery of Art, San Francisco: Asian Art 
The image of a rolled-up snake with protruding ears and a clearly marked long jaw apparatus and a tongue ending in a bizarre form resembling an ephedra branch ${ }^{21}$ (or fire?) may evoke some associations with the image of a dragon, which was expressed in a similarly circular manner in jade carved figurines. This unique pattern was made in a technique slightly different from the other Longshan ceramic products. The author of the decoration applied a red pigment to the black primed ceramic surface, which was rather rare in the products of this culture dominated by grey and black colours. There are some suggestions that the object was made of inspiration with articles decorated with red and black lacquer, ${ }^{22}$ produced by the inhabitants of today's Hangzhou Bay already during the period of the Hemudu 河姆渡 culture (5500-3300 B.C.). However, we cannot exclude the hypothesis that the bowl was made in the eastern area, and then presented as a gift on the basis of an exchange that was then performed by the elite. ${ }^{23}$

An image of an ear snake or dragon placed on a bowl discovered in the so-called the "big grave" of Taosi certainly had some symbolic significance. It could be, as Min Li suspects, a clan emblem or a religious symbol. ${ }^{24}$ The reptile was the object of worship especially among tribes inhabiting areas along great rivers. ${ }^{25}$ Under his form various water deities were imagined, believing in their extraordinary powers.

Museum of San Francisco, 2000), 11. Compare with Min Li, Social Memory and State Formation in Early China (Cambridge: Cambridge University Press, 2018), 120.

21. Li Min, Social, Memory and State Formation in Early China, 120.

22. Brian Hogarth, The golden age of Chinese archaeology. Celebrated discoveries from the People's Republic of China, 11. Compare with Li Min, Social Memory and State Formation in Early China, 120.

23. Li Liu speculates that the objects of exchange could be primarily ritual jades and drums covered with alligator skin found in the same grave in Taosi as the ceramic bowls with the pattern. See: Li Liu, The Chinese Neolithic: Trajectories to Early States (Cambridge University Press, 2005), 136.

24. Li, Social, Memory and State Formation in Early China, 120

25. Wolfram Eberhard, A dictionary of Chinese symbols: hidden symbols in Chinese life and thought (London; New York: Routledge \& Kegan Paul, 2006), 331. 


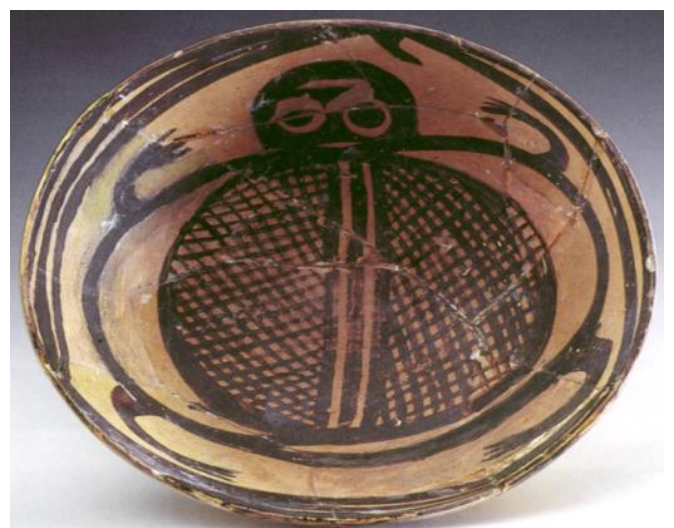

Figure 8. Painted pottery bowl with a frog design. Archaeological site: Shizhaocun, Gansu. Yangshao culture (Miaodigou period 4000-3000 BC). Gansu Provincial Museum Photography: Bogna Łakomska

Another motif appearing in the decoration of the Neolithic Chinese ceramics was also associated with water - namely, a frog and toad in various forms. One of the more discernible designs is the image of a frog painted with black paint on the bottom and internal walls of a terracotta bowl discovered in Shizhaocun 師趙村, near Tianshui 天水 (Gansu province) (Figure 8). It is a product associated with the Yangshao culture (Miaodigou period 4000-3000 BC) stylistically reminiscent of the representation of a giant salamander from a pitcher discovered in Wangjiayinwa. The similarities relate to the enhancement, and exaggerations characteristic of both vessels, as well as the method of filling the contoured space with the help of diagonal and intersecting lines resembling a mesh. Despite the excessive bluntness - the round body of the frog tightly fills the bottom of the bowl, while its head and limbs diverge into the inner walls of the vessel - the animal was captured with elemental accuracy, which indicates a thorough observation of nature. Indeed, the amphibian has a clearly defined dorsal line suggesting a composition taken from above. Moreover, the hind legs are actually longer than the front ones. A further interesting idea is the black "rim" connecting all the frog's limbs with its head and bulky belly painted on the inside walls. This treatment means that the image of the amphibian -perfectly integrated with the form of the bowl-acquires illusionist features.

The frog motif or toad occurring in the Neolithic ceramic decoration certainly had a lucky connotation resulting, for example, from the ability to produce numerous offspring by the amphibian, while its round form was probably associated with the image of the full moon, which, moreover, was reflected in various Chinese myths about, inter alia, toads that swallowed the moon, or Chang'e 嫦娥 - the wife of the victorious archer Hou Yi 后翌, who stole his reward, the elixir of life, and then escaped to the moon and was turned into a toad. ${ }^{26}$ The frog/toad, like fish, birds, pig, salamander, snake and many other animals belonged to the language of symbols supposedly to facilitate an understanding of the relationships occurring in the world. Its various images adorning ceramic dishes were not only decorative but also, if not primarily, a divination of good fortune (Figure 9).

26. Ibid, 364 . 


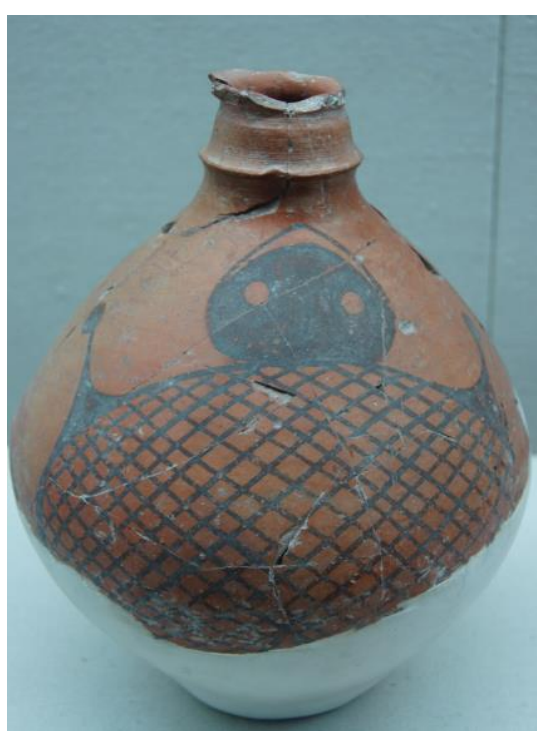

Figure 9. Painted pottery jar with a frog design. Archaeological place: Shizhaocun, Gansu. Yangshao culture (Miaodigou period 4000-3000 BC). Gansu Provincial Museum Photography: Bogna Łakomska

\section{Dogs' Designs}

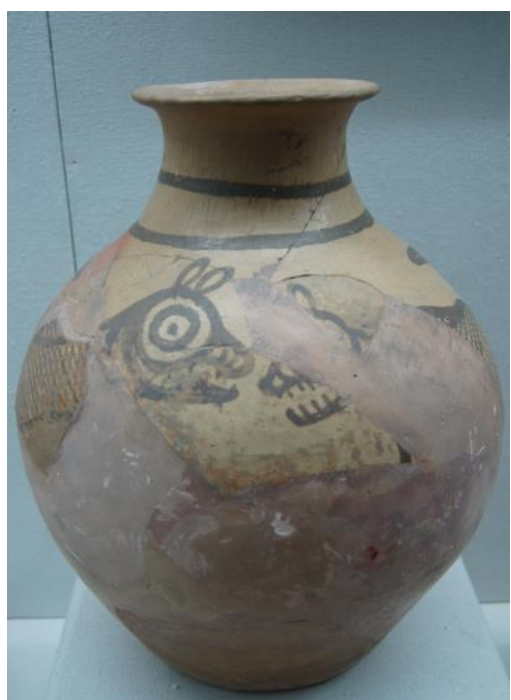

Figure 10. Painted pottery jar with fighting dogs design. Archaeological place: Shaodian, Gansu Province), Yangshao (3500-2900 BC). Gansu Provincial Museum. Gansu Provincial Museum

Photography: Bogna Łakomska

Of a slightly different character, although in all likelihood also related to a desire to attract prosperity, is a decoration in the form of dogs adorning a ceramic vessel discovered near the village of Shaodian 邵店 (Qin'an County, Gansu Province), where at first the Dadiwan 大地 culture developed (around 
5900-5200 BC), and then the Yangshao. This vessel dating back to the late Yangshao period (3500-2900 BC) was decorated with the representation of two pairs of dogs in conflict with each other (Figure 10). All the animals were painted using means typical of the Yangshao ceramic decorations, i.e. "mesh" to fill the outline silhouettes of dogs in profile, and the method suggesting emotions was also used, i.e. the effect of the big round eye. The way of painting the latter resembles the expressive eye of a heron from the discovered pitcher in Yancun. However, in addition to the standard elements used, it is apparent that the author of the image wanted to express a specific situation most likely seen in everyday life. One side of the pitcher features an image of two dogs facing each other in a horizontal position (on four legs only fragmentarily preserved), while on the other side, the animals are pushing against each other standing on their two hind legs and raising the front legs. Big eyes, open mouths with dangerous teeth protruding and raised (?) ridges inevitably suggest a fierce fight. The subject of the dispute is the fish visible only in one of the paintings. Apart from the realism of this scene, it is likely to be symbolically associated with the afterlife. ${ }^{27}$ Both images were clearly enclosed in a lane marked by two lines, one of which runs at the top and the other at the bottom, which may indicate the afterlife. In turn, fish, according to the theory of some researchers, can be interpreted as a human soul struggling in this afterlife, ${ }^{28}$ so what role do the dogs play? The results of archaeological research indicate that dog breeding began to spread through China around $8000 \mathrm{BC}$ mainly for food purposes, but also to improve hunting and safeguard homes. ${ }^{29}$ Around $7000 \mathrm{BC}$, a tradition emerged involving the burial of dogs in human graves as sacrifices who were also supposed to be guardians protecting the dead from evil forces. ${ }^{30}$ This tradition persisted in many regions for the next millennia, including in the Dadiwan and Yangshao cultures, especially between 5900 and 2900 BC. In the context of these burial rituals, the

27. Andrey V. Varenov, "Demonic dogs of Mongolian stag stones and their Chinese counterparts" (abstract), in Annali dell'Università degli Studi di Ferrara, Museologia Scientifica e Naturalistica, An interdisciplinary perspective - Dogs. Past \& Present. 1st International Conference. Rome, 14th-17th November 2018 (eds. Ivana Fiore \& Francesca Lugli), volume 14 (2018), 101. Compare with Maria Kudinova, "Dogs in the rituals and art of Neolithic cultures in China" (abstract), in: Annali dell'Università degli Studi di Ferrara, Museologia Scientifica e Naturalistica, An interdisciplinary perspective - Dogs. Past \& Present. 1st International Conference. Rome, 14th-17th November 2018 (eds. Ivana Fiore \& Francesca Lugli), volume 14 (2018), 55.

28. Andrey V. Varenov, "Demonic dogs of Mongolian stag stones and their Chinese counterparts", 101.

29. Maria Kudinova, „Домашняя собака в неолитических культурах Китая”. In: Мультидисциплинарные аспекты изучения древней и средневековой М902 истории: К 70-летию акад. В.И. Молодина. - Новосибирск: Изд-во ИАЭТ СО РАН, (2018), 97.

30. Ibid: 97, 109. 
decoration of a ceramic vase with images of fighting dogs should probably be understood as the representation of the guardians and guides of the human soul or guards located in two worlds, fighting fiercely to protect a lost soul.

\section{Conclusion}

Presenting only a fragmentary overview of the early history of animal images in Chinese art, I merely intended to signal the various social practices that influenced the acquisition of knowledge about animals, and thus discover their role not only in human life but in the world in general. Looking at animals from the perspective of art, we can discover the relationship between people and animals once sought in the context of religion, magic, aesthetics and the spiritual life of both.

Hundreds of years ago, the Chinese already realised that all things, including animals, people or the heavens were governed by the same fundamental principles, as indicated by modern sources of research. ${ }^{31}$

"This meant that all these principles were also potentially present in all things, and that differences between people and animals therefore could only be a matter of the degree to which such principles became apparent or were brought into effect. Such an approach manifested itself, for instance, in the notion of language as a continuum of all beings, in which animals, like humans, had the capacity to speak - in their own way." 32

Huainanzi 淮南子 (a collection of essays by various scholars from before 139 BC) informs, inter alia, about how much animals were valued in China (for example foxes, raccoons or insects such as silkworms or cicadas); thanks to them, as John Major points out, Chinese scholars began to think in a new way about time, space, life and death. Among others, the principles of distinguishing things between yin and yang only, or the theory of the five phases (transformations or elements) were verified. According to the new view, it was observed, for example, that animal pregnancy reveals numerological principles, and animal behaviour is a structural grid for everyday life. ${ }^{33}$ It seems that Chinese scholars have for centuries been aware of the need for humans to derive some methods of learning from animals that

31. Paul Waldau, Kimberley Ch. Patton (eds.), A Communion of Subjects: Animals in Religion, Science and Ethics (New York: Columbia University Press, 2006); Roel Sterckx, The Animal and the Daemon in Early China (Albany: State University of New York, 2002), 4; Sterckx, Siebert, Schäfer Animals Through Chinese History. Earliest Times to 1911, 6.

32. From An Introduction: Knowing Animals in China's History, Sterckx, Siebert, Schäfer, Animals Through Chinese History. Earliest Times to 1911, 6.

33. John S. Major, Heaven and Earth in Early Han Thought: Chapters Three, Four, and Five of the Huainanzi (Albany: State University of New York Press, 1993), 217-56. 
could productively enrich our knowledge. ${ }^{34}$ Chinese sages, scholars and philosophers of ancient times, according to cosmological views, believed that the highest form of knowledge could be achieved when an animal prompted a person to think about universal principles. ${ }^{35}$ It would be beneficial for us to remember this today.

\section{Bibliography}

Allsen, Thomas T. The Royal Hunt in Eurasian History. Philadelphia: University of Pennsylvania Press, 2006.

Aloi, Giovanni. Art and Animals. London-New York: I.B. Tauris, 2012.

Bavarian, Behzad, and Reiner, Lisa. Ceramic's Influence on Chinese Bronze Development. Dept. of MSEM College of Engineering and Computer Science September, 2007.

Chang, Kwang-Chih. "China on the Eve of the Historical Period." In The Cambridge History of Ancient China: from Origins of Civilisation to 221 B.C. Michael Loewe, Edward L. Shaughnessy (ed.). Cambridge: Cambridge University Press: 1999, 37-73.

Jun, E. (ed.). Masterpieces from the Gansu Provincial Museum. Lanzhou: Gansu Provincial Museum, 2006.

Eberhard, Wolfram. A dictionary of Chinese symbols: hidden symbols in Chinese life and thought. London; New York: Routledge \& Kegan Paul, 2006.

Fang, Lili. Chinese Ceramics. Cambridge: Cambridge University Press, 2011.

Hogarth, Brian. The golden age of Chinese archaeology. Celebrated discoveries from the People's Republic of China. Washington: National Gallery of Art, San Francisco: Asian Art Museum of San Francisco, 2000.

Kudinova, Maria. "Dogs in the rituals and art of Neolithic cultures in China" (abstract). In: Annali dell'Università degli Studi di Ferrara, Museologia Scientifica e Naturalistica, An interdisciplinary perspective - Dogs. Past E Present. 1st International Conference. Rome, 14th-17th November 2018 (eds. Ivana Fiore \& Francesca Lugli), volume 14 (2018): 54-55.

Kudinova, Maria. “Домашняя собака в неодитических культурах Китая”. In: Мультидисциплинарные аспекты изучения древней и средневековой М902 истории: К 70-летию акад. В.И. Мододина. - Новосибирск: Изд-во ИАЭТ СО РАН, 2018: 96-114.

Łakomska, Bogna. Kolekcjonerstwo w Chinach. Do XII wieku (Collecting in China.

34. Sterckx, Siebert, Schäfer, Animals Through Chinese History. Earliest Times to 1911, 6. Compare with Zhao Xinggen 趙杏根. 'Zhao Xinggen 趙杏根 2013. “Songdai shengtai sixiang shulue/ 宋代生態思想述略”, Poyanghu xuekan 鄱阳湖学刊Poyang Lake Academic Journal, 2013 (2), 46.

35. Sterckx, Siebert, Schäfer, Animals Through Chinese History. Earliest Times to 1911, 7. 
Until 12 century $A D)$. Warszawa-Toruń: Polish Institute of World Art Studies \& Tako Publishing House, 2015.

Li, Liu. The Chinese Neolithic: Trajectories to Early States. Cambridge: Cambridge University Press, 2005.

Liu, Jing. "Bowl with a fish motif" (Polish translation: Katarzyna Maleszko). In: 5000 lat sztuki chińskiej (5000 years of Chinese art). Warszawa: Arkady Publishing House 2014: 14.

Major, John S. Heaven and Earth in Early Han Thought: Chapters Three, Four, and Five of the Huainanzi. Albany: State University of New York Press, 1993.

Mark, Joshua J. "Pigs in Ancient China". In: Ancient History Encyclopedia, 24 January 2019. Article accessed online: https://bit.ly/37SuSuV.

Li, Min. Social Memory and State Formation in Early China. Cambridge: Cambridge University Press, 2018.

Munsterberg, Hugo. Arts of China. Tuttle Publishing, 2011.

Raphals, Lisa. Divination and Prediction in Early China and Ancient Greece. Cambridge: Cambridge University Press, 2013.

Rawson, Jessica. Chinese Jades. From the Neolithic to the Qing. London: The British Museum Press 1995.

Rawson, Jessica. "Jades and bronzes for ritual." In The British Museum Book of Chinese art, edited by Jessica Rawson. London: British Museum Press, 1996 (reprint from 1992), 44-83.

Sterckx, Roel. The Animal and the Daemon in Early China. Albany: State University of New York, 2002.

Sterckx, Roel, Siebert, Martina, Schäfer, Dagmar. Animals through Chinese History. Earliest Times to 1911. Cambridge: Cambridge University Press, 2011.

Valenstein, Suzanne G. Handbook of Chinese Ceramics. Revised and enlarged edition. New York: Metropolitan Museum of Art, 1989.

Varenov, Andrey V. "Demonic dogs of Mongolian stag stones and their Chinese counterparts" (abstract). In Annali dell'Università degli Studi di Ferrara, Museologia Scientifica e Naturalistica, An interdisciplinary perspective - Dogs. Past \& Present. 1st International Conference. Rome, 14th-17th November 2018 (eds. Ivana Fiore \& Francesca Lugli), volume 14 (2018): 99-101.

Waldau, Paul, Patton, Kimberley Ch. (eds.). A Communion of Subjects: Animals in Religion, Science and Ethics. New York: Columbia University Press, 2006.

$\mathrm{Wu}$, Hung. "The origins of Chinese painting (Paleolithic Period to Tang Dynasty)". In: Three thousand years of Chinese painting. New Haven\& London: Yale University Press; Beijing: Foreign Languages Press 1997: 15-86.

Yang, Xiaoneng. Reflections of Early China: Décor, Pictographs, and Pictorial Inscriptions. Seattle and London: The University of Washington Press, 2000.

Zhang, Zhongpei. "The Yangshao Period. Prosperity and transformation of prehistoric society". In Sarah Allan (ed.), The Formation of Chinese Civilization. An Archaeological Perspective. New Haven and London: Yale University Press, Beijing: New World Press, 2005. 
Zhao, Jing. "The bowl decorated with three fish motif" (Polish translation Katarzyna Maleszko). In: 5000 lat sztuki chińskiej (5000 years of Chinese art). Warszawa: Arkady Publishing House 2014: 15.

Zhao, Xinggen 趙杏根. “Songdai shengtai sixiang shulue/ 宋代生態思想述略”, Poyanghu xuekan 鄱阳湖学刊Poyang Lake Academic Journal, 2013 (2), 4352. 



\title{
Giuseppe Ungaretti Reading of the Correspondence with Pea, Prezzolini, Soffici and Papini from a New Perspective
}

\author{
By Vanda Srebotnjak*
}

\begin{abstract}
Giuseppe Ungaretti is one of the major representatives of 20th century Italian poetry. He was born in Alexandria, Egypt in 1888, where he also pursued his first studies. Our claim, which is in contrast with what has been argued so far by literary critics, is that the Egyptian environment in which he grew up and formed his personality played a role in shaping the author's 'colonialist' attitude. This emerges in a more detailed reading of his correspondence from the decade between 1909 and 1919. The main goal of this study is therefore to analyse a selection of these letters in order to highlight how the period in Egypt deeply influenced the author, leading him to internalize French and English colonial culture. We argue that this later induced the poet to make particular political choices such as backing Italian participation in the First World War and supporting Fascism.
\end{abstract}

\section{Introduction}

Ungaretti is mostly known as a poet of the Great War. He gained fame through his poetry collection entitled Il porto sepolto, dedicated to his experience as a soldier. The work is described by his friend and editor of the first edition Ettore Serra as: 'Such great evidence of humanity' and 'the most novel and powerful work of our contemporary literature'. ${ }^{1}$ There are many studies dedicated to him that offer to the reader a plethora of points of view and interpretations of his work. Leone Piccioni may be the most distinguished of his critics, alongside the valuable studies by Carlo Ossola and Luciano Rebay. The studies by these critics have substantially contributed to advancing the idea, as described by the critic Romano Luperini, 'of the pure poet, which this author has taken on in our literary consciousness'. ${ }^{2}$ In this way the image was created of a 'pure' poet, who through his existential anguish immerses himself in his 'buried harbour' and emerges with 'his poetry I and disperses it'. ${ }^{3}$

However, as we can see in the chapter 'Ungaretti and politics' in the

"PhD Candidate, University of Nova Gorica, Slovenia.

1. Renato Serra, Il tascapane di Ungaretti, Il mio vero Saba (Rome: Edizione di storia e letteratura, 1983), 29.

2. Renato Luperini, Letteratura e identità nazionale nel Novecento (San Cesario di Lecce: Manni, 2015), 10.

3. Leone Piccioni, Ungarettiana. Lettura della poesia, aneddoti, epistolari inediti (Florence: Vallecchi editore, 1980), 23. 
monograph 'Ungarettiana' Piccioni tried to minimize Ungaretti's involvement with Fascism, and quotes the poems 'Pietà romana' and 'Epigrafe per un caduto della rivoluzione' included in the Antologia di poeti fascisti. At the end of the analysis of the two poems Piccioni claims: "These are, therefore, the "Fascist" texts by Ungaretti: to be judged as you wish. Nothing else.' ${ }^{4}$

However, in the anthology four poems by Ungaretti were published: alongside the already quoted two, there are also '1914-1915' and 'Popolo'. '1914$1915^{\prime}$ is the introductory poem to the anthology and concludes with the following verses: 'With the fatal grace of millennia I I resume to speak in every direction, I Fruitful homeland, you are reborn valiant, I Worthy of one dying for your love. ${ }^{5}$ Rebay's study of the origins of Ungaretti's poetry states the following about the poem 'Popolo':

'Popolo' is the only poem by Ungaretti which could be associated with his 'engagement' in the political sense, but also with commemorative intentions. After leaving France [...] Ungaretti became a fervent supporter of Italian participation in the conflict [...], he was an admirer of Mussolini. 'Popolo', in fact, when it was republished in Allegria di naufragi (Vallecchi, Firenze, 1919), was dedicated to Benito Mussolini. In the preface to the later edition of the Allegria, Ungaretti confirms that 'Popolo' was suggested to him by 'the Man, who then for the first time knocked on his heart', adding that it was 'of all the poems the dearest', because it represented to him the image of loyalty'. ${ }^{6}$

This loyalty was also affirmed in the anthology Antologia di poeti fascisti published in 1935. The following extract from Ungaretti's biography in the anthology further undermines Piccioni's and Rebay's minimization of Ungaretti's adherence to Fascism:

In 1924 during the Aventinian riot and the world's agitation against Italy, [Ungaretti] goes abroad to exalt Fascism at numerous conferences, which reverberated in the major cities of Belgium and Holland. In the same year he takes part in Bologna in the first congress of Italian Fascist intellectuals, where he presents three agendas, which were the first organic Fascist programme to diffuse our spirit and our culture abroad, and he signs the manifest as an answer to that of the Aventinian intellectuals. ${ }^{7}$

On the occasion of the centenary of the First World War, there was renewed

4. Piccioni, Ungarettiana, 241-242.

5. Mariani Dell'Anguillara and Olindo Giacobbe, Antologia di poeti fascisti (Roma: Istituto Grafico Tiberino, 1935), 15.

6. Luciano Rebay, Le origini della poesia di Giuseppe Ungaretti (Roma: Storia e letteratura, 1962) 50.

7. Dell'Anguillara and Giacobbe, Antologia di poeti fascisti 258-259. 
interest in the poet, and many new studies dedicated to him were published. Among the voices that substantially conformed to the already established interpretations, as presented by Luperini ${ }^{8}$, were some works that direct their attention to the emerging discrepancy between the historical facts and what was later said and written by Ungaretti. The paper by Desmond O'Connor is significant: the author, based on a precise analysis of the historical facts, poems included in the collection Il porto sepolto, and some letters sent to the editor of the literary magazine Diana Gherardo Marone, claims that:

In the bulk of his poetry the war, when it is present ${ }^{9}$, seems little more than a pretext for exploring his own existential condition in his search for a rapport between the finite and the infinite, between past and present, between life and death. ${ }^{10}$

He therefore concludes that:

The vivid realism of the verses of Sassoon and Owen, soldier-poets in close communion with their comrades' plight, is replaced in Ungaretti by the laconically-expressed solipsism of an 'esplorazione d'un personale continente d'inferno', where poetry becomes his only solace, his own individual 'modo di progredire umanamente'.11

Another revealing contribution to the debate was provided upon the publication of some previously unpublished letters from the poet addressed to Mussolini. ${ }^{12}$ From these studies emerge documents that testify to the extent of Ungaretti's activity as an adherent of Fascist ideology. For our study it suffices to know that it was Ungaretti himself, in a personal letter to the Duce, who asked Mussolini to write the preface to his poetry collection Allegria di naufragi published in 1923, and not, as had been claimed, Piccioni through his friend Serra ${ }^{13}$, or through Soffici as claimed by Serra. ${ }^{14}$

For the purposes of this article, it is important to emphasize how some critics

8. Luperini, Letteratura e identità nazionale nel Novecento, 10.

9. The collection Il porto sepolto included 32 poems, but only eight are directly connected to the war. A.N.

10. Desmond O'Connor, "The poetry of a patriot: Ungaretti and the First World War", Journal of the Australasian Universities Language and Literature Association 56, no. 1 (2014): 201-218.

11. O'Connor, "The poetry of a patriot," 214.

12. See: Francesca Petrocchi, Scrittori italiani e fascismo. Tra sindacalismo e letteratura (Roma: Archivio Guido Izzi, 1997) and Giovanni Sedita, Gli intellettuali di Mussolini. La cultura finanziata dal fascismo (Firenze: Casa Editrice Le lettere, 2010).

13. Leone Piccioni, Vita di Ungaretti (Milano:Rizzoli editore, 1979), 141.

14. Serra, Il tascapane di Ungaretti, 38. 
still find it difficult to reconcile the poetry and the politics of the poet, particularly in regard to his engagement in the interventionist movement, his voluntary enlistment in the First World War and his active support for Fascism. By way of example, Luciano Rebay's introduction to the previously quoted essay dedicated to a brief chronology of the poet's life in the period between 1922 and 1930 omits anything in regards to the foreword by Benito Mussolini to the poetry collection Allegria di naufragi of $1923 .{ }^{15}$ Similarly, Leone Piccioni, bound to Ungaretti by a deep friendship, but also a thorough connoisseur and editor of many essays and collections dedicated to the poet, has omitted any such detail in his detailed biography dedicated to the poet's life, emphasizing the human and humanizing aspect of Ungaretti's poetry ${ }^{16}$. Moreover, this blind spot persists even among present-day authors. One such example is Emilio Filieri, who in his commentary on Ungaretti's poem 'San Martino Del Carso', composed on 27 th August 1916, not only claims that: 'There remained only a memory of the interventionist and prewar intellectual Ungaretti, with nationalistic dreams $[. . .]^{\prime 17}$, but also that: 'The "Great War" was in conclusion the last war of the Italian Risorgimento to assert the continuity with the battles for independence.'18

Less omitting of such details are some other contemporary studies, which investigate the most conspicuous discrepancies. R. Gennaro in his study I discorsi della patria ${ }^{19}$ Outlines an image of a poet more prone to metamorphosis rather than the more commonly widespread image of the 'pure' poet. However, even Gennaro in one of his studies on Ungaretti's nationalism concludes: 'It is not appropriate to talk about opportunism, but of compliance of the speech to the social conditions of his work.'20 It seems that the long tradition of the pure and innocent poet cannot be easily marred.

\section{An "Eradicated", Nomad Ungaretti without a Homeland}

Ungaretti was born in Alexandria in Egypt in 1888 to parents who had emigrated from Lucca. Rebay writes the following about his education:

Ungaretti grew up and was educated in a fundamentally French cultural

15. Rebay, Le origini della poesia di Giuseppe Ungaretti, 14.

16. Leone Piccioni, "Chapter One," in Vita di un poeta: Giuseppe Ungaretti (Milano: Rizzoli, 1970): 10-45.

17. Emilio Filieri, "Sulla Grande Guerra. Due salentini fra Ungaretti e D'Annunzio," L'Idomeneo 18 (2015): 177.

18. Filieri, "Sulla Grande Guerra," 177.

19. Gennaro Rosario, "I discorsi sulla patria," in Giuseppe Ungaretti identità e metamorfosi, Colloquio internazionale, Lucca 4-6 aprile 2002, ed. Lia Fava Guzzetta et al., (Lucca: Maria Pacini Fazzi editore, 2005), 161-179.

20. Gennaro Rosario, "La Grande Guerra e l'italianità: Il discorso nazionale di Giuseppe Ungaretti," Forum Italicum 50, n. 1 (2016): 79. 
climate. The school "Ecole Suisse Jacob" where he studied was taught in French. His closest companions in his adolescence and youth were French and Arab, but with a French cultural and language background, with the exception of Enrico Pea from Lucca. The author studied at school or during visits to the library, rich with works of modern and contemporary literature, also mostly French, [...] and finally, French was the language in which he first tried to compose poetry. ${ }^{21}$

According to Piccioni, 'Ungaretti during those years spoke French, Italian at home and with Pea, and also knew some Arabic [... $]^{22}$ Moreover, as Ungaretti recalls those years in Egypt: '[...] according to the Capitulation laws, European citizens were domiciled on the territory of their homeland, and were liable only to their national laws. ${ }^{23^{\prime}}$ This is important information in order to comprehend how privileged was the situation of the European population. The quote from Edward W. Said's work Orientalism is illuminating for our discourse:

For Barros the French presence is best seen in French schools where, as he says of a school in Alexandria, 'It is ravishing to see those little Oriental girls welcoming and so wonderfully reproducing the fantaisie and the melody [in their spoken French] of the Ile-de-France.' If France does not actually have any colonies there, she is not entirely without possessions [...] to occidentalize the Orientals, to bring them into salubrious contact with France. [...] Yet the bond (or leash) between East and West that he advocates is designed to permit a constant variety of intellectual pressure going from West to East. Barres sees things, not in terms of waves, battles, spiritual adventures, but in terms of the cultivation of intellectual imperialism, as ineradicable as it is subtle. ${ }^{24}$

Naturally, when Ungaretti decides to leave Egypt his choice falls on Paris. The opinion of the critics that Ungaretti's fundamental education was Francophone is unanimous. The poet himself stated that he indeed considers himself bilingual ${ }^{25}$. And also: '[...] if there were no Paris, I would have not had the speech. ${ }^{26}$

When the war broke out in 1914, Ungaretti left France and went to Versilia, where:

21. Rebay, Le origini della poesia di Giuseppe Ungaretti, 35.

22. Piccioni, Vita di Ungaretti, 38.

23. Piccioni, Vita di Ungaretti, 41.

24. Edward Wadie Said, Orientalism. (London: Penguin, 1977), 245-246.

25. Giuseppe Ungaretti, Lettere a Soffici 1917-1930 (Firenze: Sansoni editore, 1981), 40.

26. Gennaro Rosario, “Ungaretti, la guerra, l'identità e la storia. L'io e il noi nel Porto sepolto," in Dal nemico alla coralità Saggi critici, ed. A. Baldacci (Firenze: LoGisma, 2017), 7172 
[...] the interventionist campaign was raging, led on the national scale toward a rapid, yet unpredictable future by Mussolini, who has left Avanti! to found Il popolo d'Italia (and that is how he was introduced to Ungaretti).27

To justify Ungaretti, Piccioni asserts:

To what he said, ought to be added, he might have had been touched, albeit subconsciously (he citizen, immediate, of the world) by the nationalistic wave, the psychological situation of a "foreign resident", the constantly disappointed "love towards the homeland" cultivated from distant places, and the naturally powered desire to see his own land become part of the powerful and respected. ${ }^{28}$

Piccioni thus attributes Ungaretti's interventionism to the poet's desire to affirm his being Italian, to define his identity, on one side, but he also admits that Ungaretti aspired for Italy to become a member of the colonial powers, like France. After the Second World War, however, Ungaretti explained his support for interventionism and his voluntary enlistment in the Great War as: 'It was humbug, but men sometimes deceive themselves and follow such humbug. ${ }^{29 \text { ' }}$

This contextualization was presented with the aim of clarifying two aspects of the discourse on Ungaretti: first, the fact that he grew up and spent his formative years abroad is used as a justification for his greater need to be identified as a national poet-a need that at the time the poet believed he could satisfy in his personal and active involvement in the war, considered as the fourth war of the Italian Risorgimento ${ }^{30}$. The second aspect is the re-dimensioning and denying of his own ideological choices made before and during the war and later during the Fascist period after the Second World War.

The principal aim, however, of this article is to refute the thesis so far supported by literary critics that Ungaretti was profoundly humane and foreign to any racial hatred, but also to refute the poet's own claims, when he later attempted, after the Second World War, to diminish and hide the importance of his ideological choices. Sedita, for example, documents the following:

From July 1944 on, the lists were made available to the High Commissioner for the sanctions against Fascism, employed in the purge of the public administration (under the set of laws published on $27^{\text {th }}$ July 1944, the "Magna Carta" of the political purge). During the process of purging the Fascists in Italy, the names of those receiving steady subsidies [...] were used to identify

27. Piccioni, Vita di un poeta, 59.

28. Piccioni, Vita di un poeta, 59.

29. Piccioni, Vita di un poeta, 60.

30. Emilio Filieri, Sulla Grande Guerra, 177. 
the intellectuals 'protected by the former regime as particularly loyal "servants"'. It must have been clear during the readings of hundreds of pink files that those selected personalities that were granted a fixed grant did repay the regime according to the terms of agreement. [...]

Giuseppe Ungaretti, who was submitted to the purge procedure on $31^{\text {th }}$ July 1944, justified [...] the fixed grant which he has been receiving for years: It was a grant that was customary to give [...] I accepted it, since to me it was the same as any other grant by the State to the farmer to finish his improvement work [...]. ${ }^{31}$

Therefore, in the continuation we will try to document how it was the Francophone colonial education he received that directed him to adopt an attitude of cultural superiority and, as we will highlight, of racial hatred toward populations he considered inferior, and finally, how this background was the push that led him to adhere to interventionism and as a natural consequence to Fascism, to ensure that Italy would become a full-fledged member of the colonialist powers. The analysis of the documents will focus on finding elements that will support these two hypotheses: a) racial superiority, expressed through the denigration of other races, and b) the drive to create an Italian identity essentially on a par with the French one, or of other colonial powers. We shall conclude this brief chapter with a quotation from Piccioni:

[...] with an Arab workforce in a yard where pigs ${ }^{32}$ were bred, [...] close by were sleeping Arab workers that also worked in a bakery/furnace, naturally they had night shifts and fell asleep, and would oversleep, turning lazy. The already mentioned Battista [...] among other things also had the task to wake the lazy Arabs up, he came up with a simple method: he would wake up the pig, "because the sleep of those Arabs" said Ungaretti "was deep, and when the pig came they would jump up, and flee screaming like mad.'33

The same scene is also quoted by Rebay, although he attributed the deed to Ungaretti's mother. ${ }^{34}$

We will observe how this disrespectful and irreverent attitude towards the Arabs and their religion did not annoy Ungaretti. It is also necessary to highlight, however, how this action, regardless of the perpetrator, did not seem profoundly disrespectful to the editors, who quoted it as a funny anecdote. However, in 1969 in the "Note a cura dell'autore [Ungaretti n.d.a.] e di Ariodante Marianni" in his collection Vita di un uomo - Tutte le poesie, when he remembers the afore-mentioned anecdote, he comments: "I was offended by such behaviour, I found - and I was

31. Sedita, Gli intellettuali di Mussolini, 33

32. Piccioni, Vita di un poeta, 11.

33. Piccioni, Vita di un poeta, 22.

34. Rebay, Le origini della poesia di Giuseppe Ungaretti, 11. 
nothing more than a child - that it was not such good conduct to violate sacred beliefs. $^{35}$

\section{Unpublished Aspects of Ungaretti's Letters Corresponding to the Decade between 1909 - 1919}

Starting from the premise presented above, we will look at some letters that Ungaretti sent to his friends Enrico Pea, Giuseppe Prezzolini, Giovanni Papini and Ardengo Soffici. The correspondence with Pea started in November December of $1909{ }^{36}$, with Prezzolini on the $22^{\text {nd }}$ of March $1911^{37}$, with Papini at the end of 1914 or beginning of $1915^{38}$, and with Soffici on the $18^{\text {th }}$ of December $1917^{39}$. The initial part of Ungaretti's correspondence with Pea and Prezzolini was exchanged while the poet was still in Egypt. After 1912 the correspondence comes from Paris, from 1914 from Italy and from 1918 again from France. An analysis of letters from the postwar Egyptian period is of particular interest for understanding the poet's ideological stance.

Some interesting elements emerge from the correspondence with Enrico Pea dating from the Egyptian period, mostly characterized by cordial and formal tones. In Letter $21^{40}$, dated $26^{\text {th }}$ November 1910 from Cairo with the stamp 'Libreria - Cartoleria R. G. Lombardi. Cairo', sent to Ungaretti, with an illegible signature, we can read: 'I will gladly make sure of a positive outcome for the sale of "Fole", but considering the narrow-minded and disheartening intellectual environment here in our colony the 20 copies you sent me are too many. ${ }^{4{ }^{\prime}}$

Two points in this letter are significant for our discourse: first, the allusion to the 'disheartening' local Italian intellectual environment, therefore the 20 copies of Pea's work are too many, and second, the allusion to the colony, which allows us to frame the interpretative political and cultural context of this discourse. If we connect the letter's content to what was previously extracted from Rebay and to the privileges legally granted to Europeans in the colonies, a context emerges that shows the disparities between the Europeans and the local population, enforced by the colonial powers. It is therefore easier to comprehend Letter 25, dated December 1912 and addressed to Pea, in which Ungaretti states: 'Yesterday was

35. Giuseppe Ungaretti, Vita d'un uomo. Tutte le poesie (Milano: Mondadori editore, 1969), 498.

36. Giuseppe Ungaretti, Lettere a Enrico Pea (Milano: Libri Scheiwiller, 1983), 23.

37. Giuseppe Ungaretti, Lettere a Giuseppe Prezzolini 1911-1969 (Roma: Edizioni di Storia e Letteratura, 2000), 3.

38. Giuseppe Ungaretti Lettere a Giovanni Papini (Milano: Mondadori editore, 1988), 3.

39. Ungaretti, Lettere a Soffici 1917-1930, 3.

40. Since Ungaretti wrote more letters on the same day to the same addressee, we must refer to both the date and sequential numbering of said letters. A/N

41. Ungaretti, Lettere ad Enrico Pea, 37. 
spent with Piroddi. The mameluke was sobbing while listening to "Montignoso"'42. The expression 'mameluke' derives from the Arabic 'mamluk', meaning slave, and is used in Italian as a derogatory term; it also indicates a person lacking in judgment, stupid. In this case Ungaretti uses it to smear Mr. Piroddi.

From the details of Ungaretti's biography previously mentioned, we know that in Egypt he attended '[the] major school of Alexandria of the moment: 1 ' Ecole Suisse Jacob'43. Edward W. Said's famous work Orientalism shows how widespread and deeply rooted in the national culture was the French and British colonial attitude toward the Middle East. Every level of the cultural discourse of both nations (to which Said adds Italy as well ${ }^{44}$ ) is implicitly permeated with an attitude of superiority, which manifests itself in forms that range from a condescending benevolence with which they study the local population to extreme scorn in the form of racism. But as Said sharply notes, even the study of these populations hid the intent to rule them better with the acquired knowledge. Such study implied the stereotyped preconception that their culture was inferior and considered as primitive. This colonial point of view, an unavoidable trait of their culture, was naturally inculcated and spread through schooling and implied a more or less conscious attitude of cultural superiority of the colonial powers in the occupied territories ${ }^{45}$. Or as Said puts it:

[...] Orientalism can be discussed and analyzed as the corporate institution for dealing with the Orient-dealing with it by making statements about it, authorizing views of it, describing it, by teaching it, settling it, ruling over it [...] Moreover, so authoritative a position did Orientalism have that I believe no one writing, thinking, or acting on the Orient could do so without taking account of the limitations on thought and action imposed by Orientalism. ${ }^{46}$

We can therefore hypothesize that Ungaretti, who lived in such an environment, not only absorbed the influence but was also moulded by it. French takes on a paramount role, so much so that he decided to continue his studies in France at the Sorbonne and not, for example, Italy.

In Letter 38, dated March 1913, also addressed to Pea, Ungaretti after a long critique of Pea's work starts the last paragraph with: 'The Jew Bergson returns in a few days. ${ }^{47}$ The sentence abruptly interrupts the previous discourse and puzzles the reader as to why it is necessary to specify that Bergson is Jewish, which is entirely irrelevant to the letter's context. This is one of many examples in which

42.Ungaretti, Lettere ad Enrico Pea, 39. ("Montignoso" is a work by Pea. A/N)

43. Piccioni, Vita di un poeta, 34.

44. Said, Orientalism, 18.

45. Said, Orientalism, chapter 1.

46. Said, Orientalism, 4.

47. Ungaretti, Lettere ad Enrico Pea, 54. 
Ungaretti expressed his judgment hinting at the racial aspect. After the Second World War this aspect is not as pronounced; however, as we will describe later in the paper, the poet will make use of it again.

The content of Letter 14, sent to Prezzolini ${ }^{48}$ on the $8^{\text {th }}$ of November 1914, two years after the poet moved to Paris, is especially enlightening for the aim of our discourse. In this letter Ungaretti describes the Egyptian environment in which he grew up as well as some aspects of what Ungaretti referred to as a friendship with the Arab poet Mohammed Sceab, and this in fact reveals a different position to that which was later expressed by the poet. Moreover, the letter in the long descriptions describes an environment and attitude on the part of the poet toward his friend and also the Arab world in which he was raised which was not yet highlighted by biographers. This letter gives rise to our opinion that there was a different motivation for the poet to voluntarily join the Great War and support Fascist ideology from the beginning. The editor Maria A. Terzoli agrees with L. Piccioni in the annotation 27 to this letter that since the letter is the closest in time to the described facts, the information contained should be considered as the most reliable. ${ }^{49}$

"There was Sceab in my life, I accompanied him year after year. We weren't able to disclose anything to one another, anything. We were at school together. [...] There was an English teacher, an invincible football player, Mister Pickles [...]. Pickles would admonish Sceab: "Read Nietzsche, smoke a cigarette, and afterwards prepare for suicide." We were lost there, unsettled in Paris, the Kurdish and the one from Lucca born abroad, we never told one another a thing. He was the descendant of emirs, princes of mountain nomads, of the Sceabs, who even today rule the Kurdish, my origins were those of farmers. Different civilizations, different educations. [...] He despised the natives of Egypt, gullible and hypocrites, obsequious and savage, he enjoyed hitting the heads of the shoeshiners of Mohammed Ali Square. [...] Nestled by the procession of grim baldaquins, for each passerby they'd hit the shoeshiner and then the brushes on the cases. [...] During the breaks the trees of acacia surrounded by tables of the Cafés of the Effendi's who were playing tricchetracche ${ }^{50}$, goitry boitry ${ }^{51}$, emitting, between clicking moves of the pawns,

48. Ungaretti, Lettere a Giuseppe Prezzolini 1919-1969, $23-29$.

49. Ungaretti, Lettere a Giuseppe Prezzolini 1919-1969, 27. 'As it was already observed in Piccioni Leone, Ungaretti, la guerra, la poesia (Letter to Soffici, p. V, footnote 1) this letter offers a third version of Ungaretti's arrival in Paris: together with his friend Sceab, not before (as Ungaretti claimed in his later accounts), nor later (as it was implied from an unpublished document by Pea in Rebay's possession). Unless other direct and contemporary testimonies surface, we must consider the statements in this letter as chronologically closest.'

50. Tric-trac, a popular game among Arabs of the time A/N. 
blessed, clouds of smoke from the chichia, the hookah, whose water was gurgling, bon vivant, lying down, proper Muslims, pederasts. They will consider it a day well spent if they'd succeeded in corrupting some little Jew, tonight. - The damn money. - [...] on Saturday evenings the English military band plays and there come to listen to the "massica" 52 the Arab folk in tunics ${ }^{53}$, in their filthy shirts of a faded light blue, and wear on top - principle of civility - the jacket or paletot ala "franga", in the European manner. Sceab was of a different race. He changed his name. Mohammed Sceab introduced himself as Marcel Sceab. In Paris. But his homeland was not France. [...] Observing, while departing [for Italy $\mathrm{A} / \mathrm{N}$ ], the little Negroes, agile Nubian boys [...] springing like fleas the little Nubians. [...] In Paris, together. And we never lived in common anxiety. Every night, hours hours, on the streets of Paris blazing in the illumination orgies, in the racket, our solitude, our darkness, which did not unite us. Sceab's desperation was not my desperation. [...] He killed himself. He set the cigarette on the nightstand. [...] He destroyed all his papers, manuscripts of short stories and poetry, in the purest French, of the most ingenuous invention. [...]

And if the war anointed me Italian? [...] for me, for my personal case, the generosity of the war. For all the Italians, finally a common passion, a common certainty, finally a united Italy." 54

It should be noted that Ungaretti sent this letter to Prezzolini with the hope that his friend would publish it in the Florentine literary magazine $L a$ voce $^{55}$. A letter, as we can see, packed with information and interesting attitudes that shed light on the content of the letters quoted so far and those yet to be introduced. Firstly, Ungaretti presents a description of his relationship with Sceab that differs substantially from later ones. As suggested in the letter, according to Ungaretti, Sceab committed suicide in Paris because he did not have a homeland he could identify with. The indication of a pejorative attitude by the professor Pickles toward the Arab is not condemned by the poet and it contrasts with what was later stated in the biography edited by Piccioni: 'I am made in such a way [...]

51. In original guzzutti buzzutti, a pejorative term to indicate the goitre and the prominent belly, but the editor M. A. Terzani in her note comments: "A comical grotesque paranomasia for $[\ldots]^{\prime \prime}$.

52. Arabic term for music.

53. Expression used in the original text is "galabia".

54. Ungaretti, Lettere a Giuseppe Prezzolini 1919-1969, 23-29.

55. Ungaretti, Lettere a Giuseppe Prezzolini 1919-1969, 30. See footnote 1: 'With all probability Letter 14, sent as this one from Milan, which was perhaps sent with the hope of being published in "La Voce".' We must also consider that in 1914 Prezzolini was editor-in-chief of the magazine, to which he gave a militant tone, which turned into interventionism. A/N. 
that I do not know what the aversion toward other races or people is. ${ }^{\prime 56}$

The memory of the English professor, as quoted in Piccioni's biography:

[...] and among the teacher there was a certain Mister Pickles, teacher of English language, whom Ungaretti does not forget for his enthusiasm and continuous talking about Nietzsche. ${ }^{57}$

It also offers an image of Ungaretti that is different from that of the letter, where a denigratory attitude toward Sceab emerges. Ungaretti's insistence that the two friends had nothing in common but were from different cultures and races seems to indicate a colonial attitude that makes a distinction between Us and Them, as noted by Said ${ }^{58}$. Particularly indicative is how strongly the colonial attitude affected the indigenous people, so much so that Sceab, in an attempt to integrate better into the Francophone population, hated the indigenous people, as displayed in how he 'enjoyed hitting the heads of the shoeshiners'59. Ungaretti does not comment on or condemn such belittling behaviour, since the shoeshiners are 'gullible and hypocrites, obsequious, and savage' 60 . Ungaretti therefore assigns to the indigenous people a string of pejorative stereotypes. As Said points out, for the formulation of a stereotype:

[...] it is frequently enough to use the simple copula is. Thus, Mohammed is an imposter, [...]. No background need be given; the evidence necessary to convict Mohammed is contained in the ' is' ${ }^{6}{ }^{61}$

Through the use of the verb 'to be', and for the sole use of the verb 'to be', the attribution is associated with the person/people, becoming its inherent referential element. Moreover, Sceab's hatred created a distance between him and the indigenous people even as it joined him to the Francophone culture, which showed him the same attitude. Therefore, Sceab's act is fully accepted, and Ungaretti's description of the Arabs clearly expresses a persistent attitude of contempt, as suggested by the allusions to their filthiness, obscene physique, and deplorable sexuality. Even the reference to 'ala franga' ridicules the Arabs, who are considered incapable of properly enunciating the language of the 'civilized' nation. This is how the Other was represented and related to us, something that is expressed repeatedly in Ungaretti's correspondence. The representation of the Arab world seems to correspond perfectly to what Said described in his work:

56. Piccioni, Vita di un poeta, 16-17.

57. Piccioni, Vita di un poeta, 23.

58. Said, Orientalism, 7.

59. Ungaretti, Lettere a Giuseppe Prezzolini 1919-1969, 26.

60. Ungaretti, Lettere a Giuseppe Prezzolini 1919-1969, 26.

61. Said, Orientalism, 73. 
In the films and television the Arab is associated either with lechery or bloodthirsty dishonesty. He appears as an oversexed degenerate, capable, it is true, of cleverly devious intrigues, but essentially sadistic, treacherous, low. Slave trader, camel driver, moneychanger, colourful scoundrel $[\ldots]^{62}$

Sure enough, the image of the Arabs depicted by Ungaretti is that of pederasts, who spend their days playing instead of working, or scheming to defraud even the 'little Jews' 63 , also stigmatized and referred to by the pejorative diminutive ('ebreetti') and by the comment 'The damn money', which alludes to the image of the Jew attached to money. Not even the Nubian children can escape Ungaretti's slights, by being compared to fleas.

Even after many years Ungaretti could not shake off his attitude of superiority towards the people he grew up among. In the description of his nanny Bahita he says:

I know milk is not blood, but I believe it contributes to instill into blood stimuli for certain fantasies, certain magic, certain desperations, certain impetuosity. The Negro milk even imparts to the recipient some kind of innocence in relation to others - the Negro is pure for being a mix of meekness, of unstoppable effusiveness, of the return to the childhood of the world, which he almost succeeds to keep intact within himself. ${ }^{64}$

The unequal relationship between who gives and who takes becomes immediately clear, showcasing the colonial attitude. An array of stereotypes with which the poet depicts the Other follows, concluding with that of the 'world's childhood', which alludes to the presumed 'innocence' of primitive populations, who are therefore not yet civilized, like children who need to be educated. One could object that Ungaretti was in reality trying to express his gratitude to these people to whom he owned this primal innocence, expressed in his poetry. However, the objection does not take into account the unquestionable fact that this path is and remains a one-way path. Ungaretti is inspired by the innocence of the 'pure Negro' 65 . The West therefore draws from the Orient a renewed ingenuity, purity. It is an unequal relationship, where one side 'sucks' the milk from the other without offering anything in exchange apart from 'gratitude'.

Moreover, the description of Sceab's suicide is even more tragic, as it appears he followed Pickles' indications. If suicide is an extreme measure by means of which one chooses to pay back the living, it shows us the extent of the pressure under which Sceab was put, whether in the colonial environment in Egypt or in

62. Said, Orientalism, 287-288.

63. In the original text "ebreetti".

64. Piccioni, Vita di un poeta, 17.

65. Note the use of the equivocal terms such as "pure race" $\mathrm{A} / \mathrm{N}$. 
Paris. The tragedy of this act lies not in the fact of not being able to find one's poetry, as Ungaretti continued to claim ${ }^{66}$, but in the realization that European civilization, which he studied and had identified with to the point of changing his own name, continued to consider him inferior. Ungaretti continued to emphasize repeatedly that he did not participate in Sceab's anxiety, that their loneliness had not united them, but derived from different sources. Even though Ungaretti considered himself as 'uprooted', a nomad, since he grew up outside the borders of Italy, he had a clear understanding that he belonged to the Europeans, who enjoyed particular privileges in Egypt. Ungaretti's loneliness, therefore, might stem from his inability or unwillingness to decide which homeland to devote himself to. Ungaretti's patriotism is well understood by Said: 'Patriotism, extreme xenophobic nationalism, and downright unpleasant chauvinism are common responses to this fear. We all need some foundation on which to stand $[\ldots]^{\prime 67}$. Ungaretti's interventionism is thus a logical consequence of the poet's decisions to consider himself Italian but is simultaneously also a political choice. The latter is induced by his initial colonial education, as can be seen from the article published in Il Tempo on the $4^{\text {th }}$ January 1918:

Italy wants to be bigger, not so much territorially, which is of secondary importance, but in the soul, which it deserves; it does not want to be relegated to the fate of a tribe of Negroes; it wants to be elevated to the splendour that is traced in the two thousand years of its history of gentility. ${ }^{68}$

This can be linked to Letter 229, from November/December 1918, where he affirms:

If it weren't for the usual obtuseness of the Council, instead of spiting them, I wonder if we wouldn't have been considered by the Yugoslavs as liberators, even though we would have taken them under our tutelage. We must've had tact; have we not learned anything in contact with the French? ${ }^{69}$

This attitude is also expressed in Letter 229: 'They should not have tolerated [...] not even the Dalmatian question to be discussed? ${ }^{\prime 70}$, and in Letter 264 as well: 'His act ${ }^{71}$ is one that had to be done for the honour of our land.' Two aspects of Ungaretti's thought are made clear: first, territorial expansionism, and second, his desire to align Italy with France as a colonial but also civilizing power, made clear

66. Giuseppe Ungaretti, Il porto sepolto 1916-1996 (Udine: ristampa anastatica a cura di Mario Barenghi, 1996): 7.

67. Said, Orientalism, 334.

68. Ungaretti, Vita d'un uomo, 9.

69. Ungaretti, Lettere a Giovanni Papini, 234.

70. Ungaretti, Lettere a Giovanni Papini, 252.

71. The siege of Reka by D'Annunzio. 
by his allusion to the possible 'tutelage' of Yugoslavia, reminiscent of France's position in Egypt.

One could argue that Sceab's loneliness and desperation stemmed from the realization that he would never integrate into French culture, for he was of a different race, considered inferior to the French, which had alienated him from his own nomad culture. Ungaretti ultimately claimed Sceab had had all his work destroyed. The act confirms the interpretation of the suicide as a refusal to be part of that cultural world which had rejected him. Moreover, later on Ungaretti claimed that he had wanted to recover his friend's work, but was too late as the governess had already handed it to the police. It is unclear why there was a need for a different version, if the later interpretation Ungaretti presented of his friend's suicide was that as someone without a homeland who was unable to unleash his poetry of pain. In reality he was unleashing it, but not in his mother tongue, therefore at the end it is obvious why he decided to destroy the work created in French, part of the culture which had alienated him as well as denigrated him.

For final confirmation of what has been claimed so far, we can quote a sentence from the letter dated 19 $19^{\text {th }}$ April 1918 sent from the war front to Prezzolini, in which he states: 'After four years I will see again my chosen homeland and the sacrifice will seem even more necessary, so the barbarians don't prevail. ${ }^{72}$ 'This is an obsessive repetition in Ungaretti's correspondence, be it to Prezzolini ${ }^{73}$, Soffici ${ }^{74}$ or Papini ${ }^{75}$, that confirms a clear distinction between civilized populations (into which Ungaretti includes the Italian and French) and the barbarians. This attitude is constantly present in the letters to Soffici, Papini, Prezzolini and Pea, confirming that Ungaretti was formed in Egypt's cultural environment, but not only there, since Ungaretti continued to be exposed to such an influence in Paris as well, an integral part of French cultural discourse. Once internalized, a defined difference between an Us and a Them results in adherence to a totalitarian regime as a logical consequence. This attitude of distinction emerges repeatedly, as in Letter 256 dating from the beginning of September 1919 and addressed to Papini, which states:

I have not seen Mrs Ricou for a long time. I still cherish her, but there has been some gossip around about a Russian Jew with whom I had an adventure; I have withdrawn myself from that household to not encounter

72. Ungaretti, Lettere a Giovanni Prezzolini 1911 - 1969, 47.

73. Ungaretti, Lettere a Giovanni Prezzolini 1911 - 1969, 47 ‘[...] so the barbarians will not prevail', 52 'I am sure the crudes will not prevail'

74. Ungaretti, Lettere a Soffici 1917-1930, 27 'they cannot prevail', 29 'The roughs will not prevail', 35 '[...] we will must continue until we crash the "roughs"'.

75. Ungaretti, Lettere a Giovanni Papini, 209 'nailed to the events, with such violent hope, that borders on desperation: "they will not prevail"', 211 'but the roughs must not prevail [...] we cannot leave our civilization to die like cowards', '[...] so it will not be insulted by the "roughs", who will not prevail". 
again that woman, who with her improbable jealousy, was annoying me at a time when I was most agitated. ${ }^{76}$

The following letter, dated $15^{\text {th }}$ September 1919, continues: 'Yesterday the painter Modigliani, in a public establishment, was speaking loudly of you, in a deplorable manner. I myself have sent back down that Jewish dauber's throat his bestialities! ${ }^{17}$ 'The editor of the letters to Papini, Maria Antonietta Terzoli, comments on the poet's statements in a footnote:

The hostility expressed in this letter [...] is certainly an isolated episode, to be attributed maybe to a latent anti-Semitism $[\ldots] .{ }^{78}$

In light of the previous examples, unquestionably the episode is not an isolated one: if these three references are linked to those of the 'Jew Bergson' or of 'some little Jew', they highlight the poet's attitude of racial superiority.

A final proof is offered in Letter 252, from the summer of 1919, in which Ungaretti announces to Papini a project for 'an anthology of the mostly Negro poetry and prose $^{79^{\prime}}$ At first glance it appears to undermine at least partially what was stated so far; however, besides the concise list of the content of the anthology, we can read: 'marvelous things taken from 8000 books by consulted travelers' 80 . The statement seems to perfectly fit what Said argues: 'It does not occur to Balfour, however, to let the Egyptian speak for himself, $[\ldots]^{81^{\prime}}$ Therefore the 'Negro' anthology will be voiced by the travelers and not by the people in question.

Similarly, in Letter 97, dated $18^{\text {th }}$ February 1917, in commenting on Giosuè Carducci's poem Alle fonti del Clitumno he writes: 'We can look at him, highly Tuscan, in the depth of his heart, the anti-Semite of the "Fountains of Clitumno" lured by the nymphs, sharpening the tusks in the fetid mouth of Heine. ${ }^{82}$

And in the same letter:

But not from today, [...], this Ungaretti, [...] named the sheepish and roguish instincts of the man; one waits for the Messiah acting like victims, the other claims to be its incarnation and wants to convert, the phony has hands of velvet and iron crosses, and is Jewish or German, $[\ldots] .{ }^{83}$

76. Ungaretti, Lettere a Giovanni Papini, 277.

77. Ungaretti, Lettere a Giovanni Papini, 279.

78. Ungaretti, Lettere a Giovanni Papini, 279.

79. Ungaretti, Lettere a Giovanni Papini, 268. Italics in the original. A/N.

80. Ungaretti, Lettere a Giovanni Papini, 269.

81. Said, Orientalism, 34.

82. Ungaretti, Lettere a Giovanni Papini, 101.

83. Ungaretti, Lettere a Giovanni Papini, 101-102. 
In this case as well it does not appear that the author is annoyed by Carducci's anti-Semitism; on the contrary, it is reinforced, alleging deceit on the part of the Jewish and German. In this case the editor offers no remarks regarding the poet's statements. Similarly, there is no rebuke to Ungaretti's outburst in the postscript to Letter 149 , dated $2^{\text {th }}$ October 1917:

Have you read Il Cancelliere? Damn German; damn; must we withstand? We will resist, we will resist: there are still men capable of dying without ferocity, to save their gentility: all: if in the World there must remain beasts, they can remain alone; but oh, my God, help us with a grain of genius! ${ }^{! 4}$

Here the contrast is presented in the form of the bestiality of the enemy and the gentility of the Italians, and a belief in the superiority of one's own culture is thereby revealed. This concept is further affirmed in Letter 156, written between the $2^{\text {nd }}$ and $5^{\text {th }}$ of November 1917, alluding to the Battle of Kobarid, where Ungaretti urges his friend Papini to:

Shout at the Italians to have fortitude, to resist: courage, Papini, shout with all your strength to our people to have courage; if gentility has to be whipped from the Earth, we will let go of it at a high price: we are ready until the very last man. .5

In Letter 132, dated $7^{\text {th }}$ August 1917, he relapsed into using stereotypes:

[...] after so much sacrifice; who would bear [...] to return for nothing; a thousand times better to die all. Maybe the Germans reason so too. But why have they stirred such carnage? But why are they so rough and treacherous? The attitude of a bear and the mind of a fox; but their hearts are bladders of beer; but they can stay herded like a machine; they have nerves of steel. I hate them, I hate them with a horror, foremost because they forced me to be patient $[\ldots] .^{86}$

After two years at the front, with all the horrors he might have participated in, Ungaretti still proclaims complete martyrdom rather than succumbing to the enemy, who is called 'bestial', and additionally described using expressions such as 'roughness, treachery, slyness' and having 'a bladder instead of a heart'.

In Letter 173, dated $9^{\text {th }}$ January 1918, after the Italian politician Giovanni Giolitti expressed an adverse position to the war, Ungaretti resumes his usual pattern to smear those who disagree with him:

84. Ungaretti, Lettere a Giovanni Papini, 152.

85. Ungaretti, Letterse a Giovanni Papini, 159.

86. Ungaretti, Lettere a Giovanni Papini, 138. 
That politician is already obnoxious, giving us an impression of calamity; his return to the chamber, after plotting for three years behind the scenes, with a significant effect on the progress of things, nauseated us. He is a man without courage, with Jewish weapons; he is not Italian. ${ }^{87}$

It is implied in the context that Ungaretti still insisted on the need to continue sacrificing human lives, believing that those who were opposed were nothing but cowards operating behind the scenes, with Jewish weapons, Jews being naturally sly, for they plot behind the scenes.

Letter 272 is undated but presumably slightly precedes the letter of $21^{\text {th }}$ May 1920, where Ungaretti criticizes Benjamin Crèmieux, who expressed in the French literary magazine 'N.R.F. ${ }^{8}$ ' some doubts about Italian poetry, particularly the vociana, to which Ungaretti belonged. The poet expresses himself thusly:

It came to my knowledge that the Italian column at the Nouvelle R.F. was entrusted to a certain Benjamin Crèmieux, that one Jewish professor, whom you must've met at the Institut Francais of Florence. To begin with, it seems he considers the whole Italian production (for him the futurist movement and movement voce), you, and Soffici included as a 'demi-reussites'. Naturally as a good Jew he's convinced that all good ideas come from England, since at the N.R.F. they are affected by the 'English discharge' ${ }^{89}$

Alongside the scorn towards the Jews, the contempt is also extended here to the English, with the allusion to the 'discharge'.

In Letter 229, which is quite long and dates from approximately the end of November or beginning of December 1918, he expresses his political and ideological position in regards to the Slavic populations:

[...] that underneath us (in Italy $\mathrm{A} / \mathrm{N}$ ) palpitates the lymph, which could restore the splendour of the flowers grown only by us. I mean the remained people, after all, the most gifted on Earth, the purest, the most varied, the most sentimental, the most intelligent, the most skilful and clever, the most laborious. The constituent is needed. I closely follow Mussolini's movement, it is, believe me, the right way. We must turn that way. Order order order, harmony harmony harmony; but for now, I see nothing else but confusion confusion confusion. [...] The politics of nationalities, I was saying, was a gauntlet, through which one had to pass to win. In the meanwhile, the tripple dream of the archduke of Sarajevo is coming true. Serbia is being

87. Ungaretti, Lettere a Giovanni Papini, 174.

88. Nouvelle Revue Francaise.

89. Ungaretti, Lettere a Giovanni Papini, 297. In Italian the word "scolo" hints to the discharge in a man caused by a venereal illness. 
annexed by Yugoslavia, they will ally with Czecho-Slovakia and Poland, and afterwards, do not doubt, with Hungary. [...] Besides, I must confess, that the restlessness, the belligerent desire of those semi-barbaric hordes, which are those vile(?) Slavs, scares me. It is a furnace, which if let into Europe will ignite constant fires, if we are not careful. As with all those half primitives, half bandits, half schemers, there is a base of mysticism, there is a mine we cannot account for: it explodes without a purpose, or with such an unexpected purpose, just like the behaviour of all the people subject to hallucinations; and oh, the damage! The damage is paid by those on whom it is inflicted; but for the irresponsible, we expect like from children, to mature reasoning with age; in the meantime, we must do with what we do with children, put them in such a position that they cannot cause harm. ${ }^{90}$

It is without doubt an important passage, which clarifies and completes the frame delineated so far. Its inherent characteristics could be compared to the letter to Prezzolini in which he describes the Arabs and Sceab. The division between the virtuous Italian population, and the other one which is not even human, since the expression 'herds' alludes to beasts, is clear. It is supported by a list of denigratory stereotypes, different from those attributed to the Arabs, as they are attributed to different ethnicities. There is no doubt about the division of the world into 'civil, gentile' and 'hordes of semi-barbarians'. Thus it is not realistic to understand his poem "Soldato" (Soldier), composed in Mariano on 15th July 1916"1, as an expression of all-embracing humanity that transcends the boundaries of nationalism. Consequently, the fraternity here is meant between him and other Italian soldiers. Similar is the poem S. Martino del Carso ${ }^{92}$, where he remembers all his fellow fighters who had died without trace and all of whom the poet carries in his heart. From the line "che mi corrispondevano" (with whom I was in contact, exchanging letters), it is obvious that it was not the Others who are meant, but again the Italian soldiers.

Such an understanding of this poetry is also confirmed by Italia, the last but one poem from the same collection ${ }^{93}$, in which the poet concludes that he rests in the Italian military uniform as he would rest in his father's cradle. This clearly shows his conclusion that his decision to voluntarily join the war yielded the desired effect: the poet finally recognized himself as an Italian.

Following is Letter 234 from mid-February 1919, where Ungaretti confirms his political and ideological position: 'Mussolini entrusted me with the correspondence of the Popolo al Congresso della Pace. I love Mussolini's newspaper,

90. Ungaretti, Lettere a Giovanni Papini, 233-234.

91. Ungaretti, Il porto sepolto,1916-1996, 29

92. Ungaretti, Il porto sepolto 1916-1996, 40

93. Ungaretti, Il porto sepolto 1916-1996, 45 
which matches, for a while now, as you know, my political beliefs. ${ }^{94^{\prime}}$ And in Letter 239 from the beginning of April 1919 he concludes:

And us? If we make a move, we will have the Yugoslavs, Czechs, and Greeks on us, which give me the impression they have a secret function of police. Otherwise how would you explain the wrongful (italics in the original text $\mathrm{A} / \mathrm{N}$ ) protection of their demands, by nations that should not tolerate, after all we've done, not even the question of Dalmatia to be discussed? Ours is truly a Pyrrhic victory: we are the war's dummies! ${ }^{95}$

In this way the core of the 'vittoria mutilata' is outlined, which will lead to the expansionist policy of Mussolini's Fascism, which will show itself in the racial laws and the Special Court ${ }^{96}$, and the racist persecution of the populations in the occupied Provinces ${ }^{97}$, that is, those 'semi-barbarians, half primitives'. In Letter 264, dated November 1919, he indeed states:

I don't believe there is any money-driven machination behind D'Annunzio.

His act was of the kind needed to be done to save our Nation's honour. Remember, he went to Reka the same day as [...] the English gendarmerie was to disembark, and our troops - the Italian troupes - were considered to be unable to perform a civil action, and were replaced by an inter-allied garrison.

Remember, that no power with a smidge of self-esteem would bear such a slap in the face. [...]

If D'Annunzio and other fervent patriots (Ungaretti included, who in those days would telegraph news which was unknown to all with the exception of Tittoni and a few others) did not act...

The consequences?

At Reka, where French blood was spilled, a French legion came to the rescue, la crème de la crème of the youth to tell us 'solidarity'! 98

Even here there is a presumption to want to be part of a colonial power, like the French, the implied conceit to have all the rights to occupy during a time of

94. Ungaretti, Lettere a Giovanni Papini, 242.

95. Ungaretti, Lettere a Giovanni Papini, 252.

96. Lavo Čermelj, Slovenci in hrvatje pod Italijo med obema vojnama (Ljubljana: Slovenska matica, 1965), 299 - 302. The book was first published in 1936 in English with the title Life and Death Struggle of a National Minority. The Yugoslavs in Italy, with the intention of informing the wider public of the horrors of the Italian policy to deprive the minority of its national identity.

97. See Pietro Brignoli, Santa messa per i miei fucilati (Milano: Longanesi editore, 1973). Author's testimony of the atrocities by the Italian army in Slovenia.

98. Ungaretti Giuseppe, Lettere a Giovanni Papini, 285-286. 
peace a land that was unilaterally considered Italian.

As already noted, Ungaretti's correspondence during the conflict was not limited to Papini. During this period the poet also regularly corresponded with Ardengo Soffici. It is possible to find elements that complete the image so far outlined in these letters as well. In Letter 49 of $2^{\text {nd }}$ September 1919 Ungaretti turns to the friend admonishing him:

\section{Remember}

the French compete to prove that in "any circumstance" the people, the soldiers demonstrate the grandeur of the race. Do you want to make of the Italian race, a race ${ }^{99}$ of Negroes? ${ }^{100}$

This example as well confirms his non-egalitarian attitude, which can be linked to the 'Nubians' who 'jump like fleas' and to the 'Negro' anthology. Some of these letters also confirm his claims about Jews. Thus, in Letter 64, dated $18^{\text {th }}$ May 1920, he writes:

I had to deal - practical reports - with some Italians, and this experience made me question whether we have lost every gallantry, and were in a period of sly Jewish decadence, with the worst barbarian vulgarity. ${ }^{101}$

There is also the following one, dated $21^{\text {th }}$ May 1920, probably written at the same time as the one to Papini, where he expresses his judgment on Benjamin Crémieux: 'A Jew-man was put in charge of the Italian column at the Nouvelle R.(evue) F.(rancaise)..$^{102^{\prime}}$ And to conclude with the letter to Soffici, dated $2^{\text {th }}$ September 1919, where Ungaretti writes: 'I am not Jewish, but Catholic; I am the Italian people. ${ }^{\prime 103}$

In conclusion to what has been quoted so far, we believe it might be useful to add to this examination some quotes which outline the logical development of what has been stated above, from the education in Egypt and the experience of war to what is reported below.

Below are comments in the letter dated $23^{\text {th }}$ September 1922 addressed to Cecchi:

"The more I meet Prezzolinis and Crémieuxs (le couple parfait ${ }^{104}$ ) the more I feel we ought to adhere to Fascism: this mob of democrats, faggots, Pharisees,

99. Cursive in the original text $\mathrm{A} / \mathrm{N}$.

100. Ungaretti, Lettere a Soffici 1917-1930, 63.

101. Ungaretti, Lettere a Soffici 1917-1930, 86.

102. Ungaretti, Lettere a Soffici 1917-1930, 88.

103. Ungaretti, Lettere a Soffici 1917-1930, 64. Translation by the author of the paper, italics in the original text. $\mathrm{A} / \mathrm{N}$.

104. In French in the original text. A/N. 
ought to be hated!"105

Meanwhile, Ungaretti approaches Mussolini directly in a letter dated $5^{\text {th }}$ November 1922, to request the Duce to write the introduction to his poetry collection Allegria di naufragi:

Excellency,

"[...] Would H.E., who is consecrating the renewed Italianity, raise my faith? I address H.E. as a Renaissance man: when Italy was grand in the world, the powerful would not disdain to crown her with beauty (which is only immortal). A few lines of preface from H.E., whenever the grave State affairs will allow you a moment of repose, would for me, in the eyes of all, be of great honour [...]."

In Letter 76 dated $8^{\text {th }}$ November 1922 addressed to Soffici ${ }^{106}$ : 'Dearest, perhaps there will be founded a great Fascist newspaper in Rome. [...] Shortly there will be published a volume of lyrics - ed.[ition] of great luxury - with an introduction by Mussolini.' ${ }^{\prime 10}$

In Letter 78 dated $29^{\text {th }}$ November 1922, also to Soffici, he writes:

Beware of the democrats. Prezzolini - for example - surely, he is not a coward, but cowards surround him. All are so. I too had to suffer due to those atrocious people. And you know how liberal I am (I am not a little Arab for nothing). ${ }^{108}$

Also, in the letter dated 22 ${ }^{\text {th }}$ November 1930: 'Dear Soffici, a son was born: Antonio Benito' 109

And finally, his beliefs are shown in this letter addressed to Giuseppe De Robertis from $23^{\text {th }}$ August 1942:

"In this horrendous war everything is a game, and our own being Italians, if we don't win. [...] Brazil, which has trampled over the brain and sweat of millions of Italians, [...] to whom it owns its prosperity, just because it didn't seem appropriate to the leading caste to vindicate all those Italians called in to substitute the Negro slaves. [...] We will not return to the shame of emigration, as those bastards who wage war on us want, even if we were to

105. Piccioni, Ungarettiana, 172.

106. Petrocchi, Scrittori italiani e fascismo, 170-171.

107. Ungaretti, Lettere a Soffici 1917-1930, 101-102.

108. Ungaretti, Lettere a Soffici 1917-1930, 104.

109. Ungaretti, Lettere a Soffici 1917-1930, 128. 
die from the first to the last."110

The idea of sacrifice, which we have seen earlier, recurs here, but in this case for the sake of 'the actual being Italian'. In the poet's mind they must wash off the shame of the Italians who emigrated to Brazil being exploited like Negro slaves, because their position is among the powers of the 'gentiles'. The numerous public statements made by Ungaretti that he was against the war are undermined by this passage. He persists in calling for the massacre of human beings, so as not to witness his people fall into the disgrace of being regarded at the same level as black slaves.

At 80 years old, Ungaretti writes to Piccioni:

I will tell you one more thing; in New York, I have smoked marijuana with a beautiful Jew, one other "young" and another beautiful Jew, at the apartment of the first. It had no effect, absolutely none; I do not know why they smoke it.

But the girl was voluptuous $[\ldots]^{111}$

Considering that the focus is on him smoking marijuana, it is not clear to the why it is necessary to specify the woman's ethnicity and relegate the "young" to a simple adjective "other". Or in Letter 175 of $24^{\text {th }}$ June 1963 addressed to Piccioni: "She's a Gypsy, but with a rare sharp insight. ${ }^{112}$ " Even in the letter 263, dated 30th May 1967:

We were $[\ldots]$ initiated to the Candomblé and I am now under the guidance of Oxalà [...]. I even have the collar [...] of the conversion. [...] Truly this is only a joke from the faith's point of view, but it lets us uncover the secrets of a population that date back to the beginning of mankind. ${ }^{113}$

This statement also displays all those colonial traits so far examined. The experimenting with 'primordial' rites, which cannot be but a joke compared to Ungaretti's 'true' faith, is the proof. The attitude is one of condescending superiority coupled with curiosity towards the Other, who is to be studied but not respected.

110.Fabio Pierangeli, Ombre e presenze. Ungaretti e il secondo mestiere (1919-1937) (Napoli: Paolo Loffredo iniziative editorial, 2016), 47 (Footnote 53).

111. Piccioni, Ungarettiana, 14.

112. Leone Piccioni, Giuseppe Ungaretti/L'allegria è il mio elemento. Trecento lettere con Leone Piccioni. (Milano: Oscar Mondadori, 2013), 218.

113. Piccioni, Giuseppe Ungaretti/ L'allegria è il mio elemento, 305. 


\section{Conclusions}

This is therefore Ungaretti's position in regards to the racial question that emerges from his letters from 1909, and his support of Mussolini and Fascism to the point that he names his own child after the Duce. Through this analysis of the letters emerges an aspect of Ungaretti's thought which is rooted in the poet's childhood dominated by the cultural environment of Egypt. It is the attitude of the colonial powers, who authorized themselves to decide the fate of the indigenous populations, as they were considered cultureless and therefore incapable of governing themselves. Ungaretti, once the politicalcultural environment had changed, tried with the help of some critics to minimize this behaviour if not deny it completely. This is therefore a characteristic of the poet, which is hardly in keeping with the definition of the pure and humane poet. We believe it necessary to insert a passage of the speech given by Ungaretti in Gorizia on $20^{\text {th }}$ May 1966 on the occasion of the fiftieth anniversary of the publication of his collection Il porto sepolto:

The name of Gorizia after fifty years signifies again for me what it used to signify for us soldiers in a Karst of terror. It wasn't the name of a victory there are no victories on earth, if not blasphemous illusions - but the name of a common suffering, ours and that of those who stood in front of us, and were called the enemy, but we, despite doing our duty without cowardice, called them in our hearts brothers. Yesterday I again walked those places in the Karst [...] It was then, [...] we heard sprouting, growing in our souls the true strength, $[\ldots]$ it was the sentiments that every man is, without limitations or distinctions, when he doesn't betray himself, brother to any other man, brother as if the other could not be less similar to him like another self. ${ }^{114}$

This is the poet's attitude in 1966, where he emphasizes his egalitarian thought, which would be fully comprehensible if not for the fact that he transposes it in time, bringing it back by fifty years.

From our point of view, however, the contradictions, the 'shadows and presences', and the metamorphosis which emerge from this reading of his correspondence indicate rather a: '[...] dramatic "duplicity" (in which) resides probably the deepest, most suggestive, dramatic, ironic and not yet entirely explored trait of Ungaretti. ${ }^{115^{\prime}}$

114. Stefano Verdino, “Ungaretti ed il sentimento della guerra," Cuadernos de Filología Italiana 22, (2015): 192-193.

115. Gennaro Rosario, Le patrie della poesia. Ungaretti, Bergson e altri saggi (Firenze: Cadmo edizioni, 2004), 40. 


\section{Bibliography}

Brignoli, Pietro. Santa messa per i miei fucilati. Milano: Longanesi editore, 1973.

Čermelj, Lavo. Slovenci in hrvatje pod Italijo med obema vojnama. Ljubljana: Slovenska matica, 1965.

Dell'Anguillara, Mariani, and Olindo Giacobbe. Antologia di poeti fascisti. Roma: Istituto Grafico Tiberino, 1935.

Filieri, Emilio. “Sulla Grande Guerra. Due salentini fra Ungaretti e D'Annunzio." L'Idomeneo, 18. (2015): 175-198.

Luperini, Renato. Letteratura e identità nazionale nel Novecento. San Cesario di Lecce: Manni, 2015.

O'Connor, Desmond. "The poetry of a patriot: Ungaretti and the First World War.", Journal of the Australasian Universities Language and Literature Association 56, no. 1 (2014): 201-218.

Petrocchi, Francesca. Scrittori italiani e fascismo. Tra sindacalismo e lettura. Roma: Archivio Guido Izzi, 1997.

Piccioni, Leone. Vita di un poeta: Giuseppe Ungaretti. Milano: Rizzoli editore, 1970.

Piccioni, Leone.Vita di Ungaretti. Milano: Rizzoli editore, 1979.

Piccioni, Leone. Ungarettiana. Lettura della poesia, aneddoti, epistolari inediti. Firenze: Vallecchi editore, 1980.

Piccioni, Leone. Giuseppe Ungaretti/L'allegria è il mio elemento. Trecento lettere con Leone Piccioni. Milano: Oscar Mondadori editore, 2013.

Pierangeli, Fabio. Ombre e presenze. Ungaretti e il secondo mestiere. Napoli: Paolo Loffredo iniziative editoriali, 2016.

Rebay, Luciano. Le origini della poesia di Giuseppe Ungaretti. Roma: Storia e letteratura, 1962.

Rosario, Gennaro. “La Grande Guerra e l'italianità: Il discorso nazionale di Giuseppe Ungaretti," Forum Italicum 50, no. 1 (2016): 79.

Rosario, Gennaro, Le patrie della poesia. Ungaretti, Bergson e altri saggi. Firenze: Cadmo, 2004.

Rosario, Gennaro. "I discorsi sulla patria," In Giuseppe Ungaretti identità e metamorfosi, Colloquio internazionale, Lucca 4-6 aprile 2002. Lucca: Maria Pacini Fazzi editore, 2005.

Rosario, Gennaro. “Ungaretti, la guerra, l'identità e la storia. L'io e il noi nel Porto sepolto," in Dal nemico alla coralità Saggi critici, ed. A. Baldacci. Firenze: LoGisma, 2017: 67-74.

Said, Edwaed Wadie. Orientalism. London: Penguin, 1977.

Sedita, Giovanni. 2010. Gli intellettuali di Mussolini. La cultura finanziata del fascismo. Firenze: Casa Editrice Le lettere,2010.

Serra, Renato, Il tascapane di Ungaretti, Il mio vero Saba. Roma: Edizione di storia e letteratura, 1983.

Ungaretti Giuseppe, Il porto sepolto 1916-1996. Udine: ristampa anastatica a cura di Mario Barenghi, 1996. 
Ungaretti, Giuseppe. Lettere a Soffici 1917-1930. Firenze: Sansoni editore, 1981.

Ungaretti, Giuseppe. Lettere a Enrico Pea. Milano: Libri Scheiwiller, 1983.

Ungaretti, Giuseppe. Vita d'un uomo. Tutte le poesie. Milano: Mondadori editore, 1969.

Ungaretti, Giuseppe. Lettere a Giovanni Papini. Milano: Mondadori editore, 1988.

Ungaretti Giuseppe, Lettere a Giuseppe Prezzolini 1911-1969. Roma: Edizioni di Storia e Letteratura, 2000.

Verdino, Stefano. “Ungaretti ed il sentimento della guerra," In Cuadernos de Filología Italiana 22. (2015): 181-194. 